\title{
Bioactive phenolic compounds, metabolism and properties: a review on valuable chemical compounds in Scots pine and Norway spruce
}

\author{
Sari Metsämuuronen · Heli Sirén
}
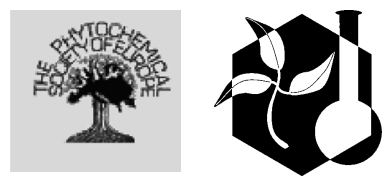

Received: 30 January 2019/Accepted: 5 July 2019/Published online: 22 July 2019

(C) The Author(s) 2019

\begin{abstract}
Phenolics and extracted phenolic compounds of Scots pine (Pinus sylvestris) and Norway spruce (Picea abies) show antibacterial activity against several bacteria. The majority of phenolic compounds are stilbenes, flavonoids, proanthocyanidins, phenolic acids, and lignans that are biosynthesized in the wood through the phenylpropanoid pathway. In Scots pine ( $P$. sylvestris), the most abundant phenolic and antibacterial compounds are pinosylvin-type stilbenes and flavonol- and dihydroflavonol-type flavonoids, such as kaempferol, quercetin, and taxifolin and their derivatives. In Norway spruce ( $P$. abies) on the other hand, the main stilbene is resveratrol and the major flavonoids are quercetin and myricetin. In general, when the results from the literature regarding the activities of flavonoid glycosides and their aglycones against a total of twenty-one microorganisms are summarized, it was found that phenolic glycosides are less active than the corresponding aglycones, although a number of exceptions are also known. The aglycones in plants respond to various kinds of biotic stress. Synergistic
\end{abstract}

S. Metsämuuronen

Department of Chemical Technology, Lappeenranta

University of Technology, P.O. Box 20,

53851 Lappeenranta, Finland

\section{H. Sirén $(\bowtie)$}

Department of Chemistry, University of Helsinki,

P.O. Box 55, 00014 Helsinki, Finland

e-mail: heli.m.siren@helsinki.fi effects between aglycones and their glycosides have been observed. Minimum inhibition concentrations of below $10 \mathrm{mg} \mathrm{L}^{-1}$ against bacteria have been reported for gallic acid, apigenin, and several methylated and acylated flavonols present in these industrially important trees. In general, the phenolic compounds are more active against Gram-positive bacteria, but apigenin is reported to exhibit strong activity against Gram-negative bacteria. The present review lists some of the biosynthesis pathways for the antibacterial phenolic metabolites found in Scots pine (P. sylvestris) and Norway spruce (P. abies). The antimicrobial activity of the compounds is collected and compared to gather information about the most effective secondary metabolites.

Keywords Antibacterial compounds - Metabolic pathway · Plant enzymes · Norway spruce $\cdot$ Scots pine . Wood $\cdot$ Phenols

$\begin{array}{ll}\text { Abbreviations } \\ \text { ASE } & \text { Accelerated solvent extractor } \\ \text { ANS } & \text { Anthocyanidin synthase } \\ \text { CHS } & \text { Chalcone synthase } \\ \text { CoA } & \text { Coenzyme A } \\ \text { DFR } & \text { Dihydroflavonol 4-reductase } \\ \text { DNA } & \text { Deoxyribonucleic acid } \\ \text { dPCD } & \text { Developmentally programmed cell death } \\ \text { dw } & \text { Dry weight } \\ \text { FSI } & \text { Flavone synthase }\end{array}$




\begin{tabular}{|c|c|}
\hline FLS & Flavonol synthase \\
\hline LAR & Leucoanthocyanidin reductase \\
\hline LDL & Low density lipoproteins \\
\hline $\mathrm{MBC}$ & $\begin{array}{l}\text { Minimum or minimal bactericidal } \\
\text { concentration }\end{array}$ \\
\hline MRSA & Methicillin resistant Staphylococcus aureus \\
\hline MIC & $\begin{array}{l}\text { Minimum or minimal inhibitory } \\
\text { concentration }\end{array}$ \\
\hline PMT & $\begin{array}{l}1,2 \text { pinosylvin O-methyltransferase genes } 1 \\
\text { and } 2\end{array}$ \\
\hline PKS & Polyketide synthase enzymes \\
\hline SSF & Solid state fermentation \\
\hline STS & Stilbene synthase \\
\hline VRE & Vancomycin-resistant enterococci \\
\hline $\mathrm{w} / \mathrm{w}$ & Weight per weight \\
\hline
\end{tabular}

\section{Background}

Utilization of wood-based compounds, extracts, and biomass has increased enormously (Rauha et al. 2000; Jansson et al. 2013; Boden et al. 2014; Ganthaler et al. 2017). Structural components of wood (cellulose, hemicelluloses, and lignin) and other organic substances which are integrated to biomass conversion processes, are the basic materials of biorefineries. Wood contains high molecular weight compounds, but also a wide variety of low molecular mass compounds known as extractives. The small compounds can be separated from the high molecular and water-insoluble wood constituents through using various kinds of extraction techniques. Thus, the industrial use of wood components has increased and even extracts are now used as starting fluids and mixtures in health products and industrial chemicals including botulin, furfural derivatives, stilbens, tannins, flavonoids, tall oil, and resin (Roitto et al. 2008; Royer et al. 2012; Long et al. 2013). Valuable bio-based compounds can be obtained directly from different parts of standing trees (Roitto et al. 2008; Royer et al. 2012; Long et al. 2013; Sirén et al. 2015; Metsämuuronen and Sirén 2014; Janusz et al. 2017; Böke et al. 2015), artificially cultivated and fermentated mixtures (Martins et al. 2011), or isolated by-products of forest industries (Mantau et al. 2010).

The compositions and concentrations of wood extracts from different wood types vary a lot. The age of wood, the harvesting time, the genetic origin, the growing period and district all influence the concentrations of the isolated bio compounds (Routa et al. 2017). The concentrations are also affected by the wood parts (needles, knots i.e. the branch bases inside tree stems, roots, barks, heartwood, and phloems) and the sampling positions (height, depth). In addition, the most commonly used sample pretreatment techniques have an enormous influence on the content of extractives. Extraction systems (hot water and supercritical fluid extractions, ultrasonication, autoclave handling, microwaving), enzyme and microbe treatments with reactions, and organic solvents, acids or bases need to be standardized, since they have effects on the yields of bioactive compounds and their concentrations. Thus, the phenolic compounds of low molecular weights may originate from hydrolysis of the wood due to degradation of the material and are not in fact the extractives from the wood. Another determinant is the analysis method used to identify and characterize the wood compounds. When sample manipulation, such as derivatization, is used to improve the sensitivity to reach the methodological levels of the instruments, the originality of the sample matrix is lost.

\section{Background for primary and secondary metabolites}

Scots pine (Pinus sylvestris) and Norway spruce (Picea abies) have been chosen for the discussion of the review, since they are the most common trees in Northern Europe. In addition, bio refinery industry with related industry focus interest to isolate new chemicals for replacing polymers with bio-compounds and investigate for reusing wastes. Extractives of pulp and paper industry contain mostly wood species of Scots pine ( $P$. sylvestris) and Norway spruce (P. abies) for new bio-based materials, energy, and bio fuel. Nowadays, the place of renewable energy is increasingly important. Biomass is the primary source of renewable energy, and therefore the "valuable compounds" are isolated to use only the rest material in energy production (Gérardin 2016).

A number of chemical compounds can be isolated from or produced in Scots pine (P. sylvestris) and Norway spruce ( $P$. abies). When native in the wood, they can be classified as primary and secondary 
metabolites. Primary metabolites have essential metabolic roles in the plant. Primary metabolites are usually described as substances that are essential chemical units of living plant cells. These fundamental substances are cellulose, hemicelluloses, polysaccharide, and lignin. Plants synthesize a vast number of small molecules that are secondary metabolites. In contrast to primary metabolites, they are not necessary for tissue growth. Secondary metabolites are formed by evolution to defend plants against harmful attacks by herbivores, pathogens, insects, plant-eating animals, and UV radiation (Wink 2003). Therefore, their composition is plant-specific and genetically controlled. Secondary metabolites are classified as aliphatic compounds (terpenes and terpenoids, resin acids, sterols, fats, waxes, fatty acids), phenolic compounds (flavonoids, simple phenols, tannins, stilbenes), and other secondary metabolites (sugars, alkaloids). Phenolic compounds comprise a structurally and functionally diverse group of aromatic hydrocarbon rings, and usually at least one hydroxyl group. In general, secondary metabolites from wood species from temperate regions have fungicidal, fungistatic, or bactericidal properties (Routa et al. 2017; Schultz and Nicola 2000; Treutter 2006; Ganthaler et al. 2017).

\section{Usability of primary and secondary metabolites}

There have been attempts to commercialize secondary metabolites of Scots pine (P. sylvestris) and Norway spruce ( $P$. abies), and to manufacture health-promoting pharmaceuticals, nutrients, and products for health and welfare. Needless to say that using wood residues on the ground is economic only, when valuable chemical products are useful for large scale industry production, like pine needle oil used in cosmetics and personal care products, acyclic alcohols and essential oils in perfumes and wood flavor compounds in food.

Bark and knotwood are the most economically available wood residues, as they are collected in stems and transported to saw mills and pulp mills. Then, bark is removed from the stem and knotwood is separated from wood chips. Unfortunately, the majority of leaves, branches, bark, roots, and stump materials containing valuable metabolites is wasted. Although large amounts of bark are used in energy, pulp, and paper production, lately stumps have also been collected for energy production. However, usually wood residues are left in the forest after the harvesting of tree trunks. There is little research in literature describing what compounds in wood parts are beneficial for production and for energy industry, and in what concentrations they exist. Removal techniques for advantageous chemicals from stumps and thick roots can be used to extract commercially valuable biochemicals (Berg 2014; Hakkila 2012), like phenolics, stilbenes, flavonoids, flavanones, flavonols, flavan-3-ols, anthocyanidins, and proanthocyanidins.

The oily tar from the Scots pine ( $P$. sylvestris) tree has traditionally been prepared from terpenes and terpenoids and for thousands of years, utilized as a preservative for timber (Holmbom 2011). Furthermore, oleoresin, terpene, and lipid components of Scots pine (P. sylvestris) and Norway spruce (P. abies) have been extracted as by-products in wood pulping processes. They have been further refined to turpentine and tall-oil and, more recently, also used for the production of biofuel (Holmbom 2011). Phenolic compounds are involved in resistance mechanisms as precursors to defense-related compounds or synthesis of polymers. They are supposed to modulate the activity of other phytochemicals (Schultz and Nicolas 2000; Treutter 2006; Ganthaler et al. 2017). Phenolic metabolites are considered a very important part of both constitutive and inducible defense mechanisms of trees (Chong et al. 2009).

Phenolic stilbenes, flavonoids, and lignans are potential substances for biorefineries owing to their biological properties (Conde et al. 2013; Li et al. 2012). Flavonoids have biological, nutraceutical, and clinical effects (Maimoona et al. 2011; Li et al. 2012). Furthermore, lignans possess chemopreventive properties (Lampe Ríos and Recio 2005; Li et al. 2012; Saxena 2015) that are used for health and welfare products. Lately, the interest in the phenolic compounds of these conifers has increased.

Although some biologically active plants, mainly herbaceous species, have been used as folk medicines for centuries, much less is known about the bioactive phenolic compounds in coniferous wood.

Stilbenes are natural defense polyphenols that occur in many plant species. Pinosylvin (3,5-dihydroxy-trans-stilbene) is a naturally occurring transstilbenoid, which is mainly found in heartwood of Pinus species and exists in high concentrations in bark. Stilbene is suggested to represent an inexpensive 
polyphenol with considerable potential for diverse health-promoting applications (Reinisalo et al. 2015), like effect compounds against aging-related diseases.

Lignan has various kinds of phenylpropanoid (propylbenzene) type molecules which are found in all plants. Lignan is produced by secondary metabolic pathways. Lignans such as 7-hydroxy-matairesinol, secoisolariciresinol, lariciresinol, and nortrachelogenin are predominant in a large proportion of the industrially important softwood species (Holmbom et al. 2003). The 9-epimers of 7-hydroxy divanillyl butyrolactol lignans, (7S,8R,89R,99R)-4,49,7-trihydroxy-3,39-dimethoxy-lignano-99,99-lactol and (7S, 8R,89R,99S)-4,49,7-trihydroxy-3,39-dimethoxylignano-99,99-lactol have been identified and characterized in knotwood of Colorado spruce (Picea pungens) (Willför et al. 2005). Equal lignans have also been known to occur in several spruce, pine, and fir species, including Scots pine (P. sylvestris) and Norway spruce (P. abies).

\section{Metabolites in parts of trees}

There is a great variability in the yields of secondary phenolic metabolites between tree species, between parts of the trees, and even between individuals of different ages and botanical region (provenance) (Kähkönen et al. 1999; Harju et al. 2003; Willför et al. 2003a, b, c; Venäläinen et al. 2004; Hovelstad et al. 2006; Välimaa et al. 2007; Karppanen et al. 2008; Sirén et al. 2014). The total phenolic concentrations of $76.0,17.5$, and $1.1 \mathrm{mg} / \mathrm{g}$ in gallic acid equivalents for dried bark, needles and heartwood, respectively (Kähkönen et al. 1999), and 6.7-13.6 mg/g in tannic acid equivalents for wood (Venäläinen et al. 2004) of Scots pine ( $P$. sylvestris) have been reported. Phenolic concentrations of $10-15 \%$ and even $30 \%$, based on dry weight (dw) in knotwood (branch stubs embedded in tree stems) of Norway spruce, and at least $10 \% \mathrm{dw}$ in knotwood of Scots pine ( $P$. sylvestris) have been reported (Willför et al. 2003b, c). Several times lower concentrations are observed in the stem wood (Willför et al. 2003c). A large variety of low-molecular phenolic compounds, phenylpropanoids (tannins, lignans, flavonoids, and stilbenes) are found in these extracts, especially in the bark and knots. However, few phenolic compounds dominate in the knotwood extracts of most softwood species. For example, more than half of the hydrophilic extractives of knotwood of Norway spruce (P. abies) are lignans (Willför et al. 2003b).

Knotwood compounds of Scots pine (P. sylvestris) have been identified from extracts prepared into hydrophilic organic solvents and ethanol. Earlier only medium-large compounds with molar masses of 500-600 Da were identified due to the limitations of analytical instruments and methods. Lately however, high molecular mass fractions from 500 to $2200 \mathrm{Da}$ isolated from knotwood of Scots pine (P. sylvestris) have been obtained. These compounds were mainly oligomers of hydroxylated resin acids, especially dehydroabietic acid, but also fatty acids, stilbenes, and sterols. The discovery of the resin acids dimers in native wood was a new finding, since they were not previously identified in ethanol extracts (Smeds et al. 2018). The amounts of many lignans in softwood are extremely low. Their amounts are less than $0.1 \mathrm{mg} / \mathrm{g}$ (Fang et al. 2013). The fact is the sample preparation which probably influences their identification in nonconcentrated extracts.

\section{Metabolites in wood species}

\section{Phenolic extractives}

Phenolic extracts of Scots pine ( $P$. sylvestris) and Norway spruce ( $P$. abies) have been reported to exhibit antioxidative (Kähkönen et al. 1999; Willför et al. 2003a; Pietarinen et al. 2006), antifungal (Harju et al. 2003; Venäläinen et al. 2004), and antibacterial activity (Välimaa et al. 2007; Lindberg et al. 2004; Rauha et al. 2000; Vainio-Kaila et al. 2017). A phloem extract (Rauha et al. 2000) and a knotwood extract from Scots pine (P. sylvestris) (Berg 2014; Lindberg et al. 2004) as well as a needle extract from Pinus massoniana (Feng et al. 2010) have been shown to inhibit growth of several microorganisms, including bacteria and yeast. Therefore, they have been supposed to contain various kinds of antimicrobial phenolic compounds, including antimicrobial phenolics. Mycorrhizal fungi have long been recognized as important microorganisms that promote tree growth and survival (Strzelczyk and Li 2000). In Scots pine (P. sylvestris) the major genera of endophytic bacteria found were Methylobacterium, Pseudomonas (Pirttilä et al. 2000; Strzelczyk and Li 2000), Bacillus and 
Paenibacillus and bacteria closely related to Bacillus subtilis, Bacillus licheniformis, Paenibacillus spp., and Acinetobacter calcoaceticus (Izumi et al. 2008). In bud of intact Scots pine ( $P$. sylvestris), the endophytes were identified as genera Methylobacterium and Pseudomonas, and the yeast as Rhodotorula minuta (Pirttilä et al. 2008). The trees contain various kinds of of phenolic compounds, which have antibacterial properties. In this case the wood structural components and extractives have been investigated against methicillin-resistant Staphylococcus aureus (MRSA) and Escherichia coli O157:H7 by placing bacterial inoculum on surfaces for incubation (Vainio-Kaila et al. 2017). Only the extract of Scots pine ( $P$. sylvestris) heartwood showed antibacterial properties against E. coli O157:H7. The MRSA bacteria was susceptible to extracts of Scots pine ( $P$. sylvestris) and Norway spruce ( $P$. abies) species such as heartwood, sapwood, and milled wood lignin.

\section{General biosynthetic of phenylpropanoids}

The majority of phenolic compounds in plants are synthesized via the phenylpropanoid pathway (Iriti and Faoro 2009). They belong to a group of phenylalanine derivatives, which have a basic C6-C3 carbon skeleton. Many of them belong to phytoalexins, which are antimicrobial agents naturally synthesized in the wood to respond to microorganism attacks (Ganthaler et al. 2017). The synthesis of phytoalexins is initiated through signal-transduction pathways linked to the perception of pathogen receptors encoded by host resistance genes (Dixon 2001). Phenylalanine and tyrosine that are the precursors in phenylpropanoids biosynthesis, are synthesized via the shikimate (shikimic acid) pathway (Iriti and Faoro 2009), which is present in fungi and bacteria. The general phenylpropanoid metabolism generates an enormous array of secondary metabolites based on the few intermediates of the shikimate pathway (Vogt 2010). Furthermore, hydroxycinnamic acid and its esters are amplified in several ways by a combination of reductases, oxygenases, and transferases resulting in an organ and developmentally specific pattern of metabolites, which is characteristic for each plant species (Vogt 2010).

The general phenylpropanoid pathway implies that the phenylalanine ammonia-lyase (PAL, EC 4.3.1.5) enzyme catalyses the synthesis process by deamination of phenylalanine to cinnamic acid, which is further catalysed by tyrosine ammonia lyase (EC 4.3.1.23) to produce $p$-coumaric acid. Both cinnamic acid and $p$-coumaric acid are catalysed by 4-coumaroyl: coentzyme A (CoA) ligase (EC 6.2.1.12) to cinnamoyl-CoA and $p$-coumaroyl-CoA. These phenol products are precursors of the polyphenolic compounds, which are stilbenes (C6-C2-C6 carbon skeleton), flavonoids (C6-C3-C6 carbon skeleton), and lignans ((C6-C3) $)_{2}$ carbon skeleton) (Dixon 2001; Vogt 2010; Kodan et al. 2002; Stevanovic et al. 2009; Lim and Koffas 2010; Tanase et al. 2018). Especially, $p$ coumaroyl-CoA is a key intermediate in the biosynthesis of a number of phenylpropanoids. The diversity of phenylpropanoids is caused by hydroxylation, methylation, acylation, isomerisation, oligomerization and/or glycosylation (conjugation with various kinds of carbohydrates) which modify plants secondary metabolites to products with increased stability and water solubility. The procedure also inactivates and detoxificates the compounds (Gachon et al. 2005). In general, phenylpropanoids are stored as glycosylated forms in the vacuole, from where they can be released and further cleaved by $\beta$-glycosidases (EC 3.2.1.x) into their active aglycone forms e.g. against budworms and insects (Gachon et al. 2005; Mageroy et al. 2015, 2017).

\section{Stilbenes}

Scots pine (P. sylvestris) and Norway spruce (P. abies) synthetize different kinds of secondary metabolites. The most important of them in P. sylvestris include stilbenes and terpenes that defend the tree against pests and pathogens. Their role is also to prevent rotting. Many plant families are known to produce stilbenes, such as Pinaceae, Gnetaceae, Myrtaceae, Poaceae, Cyperaceae, Liliaceae, Myrtaceae, Fabaceae, Moraceae, Fagaceae, Palmaceae, Polygonaceae, and Vitaceae (see Almagro et al. 2013). No stilbenes could be detected in Norway spruce (Hovelstad et al. 2006). The amount of stilbenes in Scots pine varies a lot from tree to tree (Paasela 2017).

"Many plant families are known to produce stilbenes, such as Pinaceae, Gnetaceae, Myrtaceae, Poaceae, Cyperaceae, Liliaceae, Myrtaceae, Fabaceae, 
Moraceae, Fagaceae, Palmaceae, Polygonaceae, and Vitaceae (see Almagro et al. 2013)"

Lipophilic extracts have been noticed to contain the same major components that are found in the main wood material. The inner bark layer contains over $10 \%$ of stilbene glucosides. Piceatannol (astringenin) is then the main stilbene. Tannins of the proanthocyanidin type were extracted with non-boiling hot water, but extraction with pressurized hot water at $140{ }^{\circ} \mathrm{C}$ or $160{ }^{\circ} \mathrm{C}$ gave non-cellulosic polysaccharides (yields of 11-14\%). These polysaccharides were original bark basis containing pectin polysaccharides, which are built up of arabinose, galacturonic acid, and rhamnose. The pectin polysaccharides are of potential interest, although they need to be studied further to obtain more scientifically important information. The amounts and the true chemical character of lignin are not yet either fully elucidated (Krogell et al. 2012). However, it is known that the inner bark contains two times more cellulose than the outer bark, but the opposite situation was observed for lignin, which was determined by Klason "lignin" methodology (Krogell et al. 2012). Among the potentially valuable components, stilbene glucosides could be extracted with pure water even at low temperatures, but tannins that are more hydrophobic needed hot water in extraction. It was also shown that fungal infection induced the Norway spruce (P. abies) to produce higher levels of stilbene synthase (STS) transcript and tetrahydroxylated stilbene glycosides, and that these compounds had antifungal activity (Hammerbacher et al. 2011).

\section{Biosynthesis of stilbenes and stilbenoids}

The biosynthesis of stilbene in Scots pine ( $P$. sylvestris) and Norway spruce (P. abies) (Fig. 1) is suggested to occur in situ in the transition zone between the sapwood and heartwood. Comparably, the resin acids are primarily composed only in the sapwood. The most important stilbene derivatives are hydroxylated compounds having two phenol moieties linked by a C2 bridge (Chong et al. 2009). They are pinosylvin and its monomethylether, which have important functions as phytoalexins in active defense (Paasela 2017).

Stilbene biosynthesis starts from cinnamoyl-CoA, $p$-coumaroyl-CoA and caffeoyl-CoA and ends up to
Fig. 1 Biosyntheses of stilbenes commonly found in Scots pine and Norway spruce. $\mathrm{CoA}$ coenzyme A; $P M T$ pinosylvin-3-Omethyltransferase; PSS pinosylvin synthase; STS stilbene synthase. Collected from papers of Kodan et al. (2002), Lim and Koffas (2010), Chong et al. (2009), and Fliegmann et al. (1992)

piceacides or in the presence of dihydrocinnamoylCoA to dihydropinosylvin monomethyl ether.

Pinosylvin is synthetized from malonyl-CoA and cinnamoyl-CoA with release of coenzyme A and carbon dioxide. Biosyntheses employing cinnamic acid as the initial point are rare compared to the more common use of $p$-coumaric acid which is the most abundant isomer of hydroxylcinnamic acid. It is reported that pinosylvin can be isolated from heartwood and roots of Scots pine ( $P$. sylvestris) (Chiron et al. 2000).

It has been shown that a bifunctional nuclease correlated enzyme involved in developmentally programmed cell death (dPCD) can be used as the marker for heartwood to investigate concentrations of stilbene and to identify biosynthesis products when investigating the effect of season processes. Thus, it has been clarified that softwood is initiated by intrinsic internal plant based factors but not environmental factors. Furthermore, the expression of pinosylvin- $O$-methyltransferase gene (PMT1) is not induced under stilbeneforming conditions. Most probably, therefore PMT1 is not involved in the stilbene pathway. However, instead of PMT1, a new PMT-encoding gene PMT2 has been identified, that has shown an expression pattern that is very similar to that processed with the stilbene synthase gene. In contrast to the multifunctional PMT1, PMT2 is related to methylated pinosylvin with high specificity, since it follows closely the stilbene biosynthesis (Paasela et al. 2017).

Formation of stilbenes is controlled by stilbene synthases (EC 2.3.1.95) which are members of the chalcone synthase superfamily of type III polyketide synthases (Chong et al. 2009). They are classified into $p$-coumaroyl-CoA- and cinnamoyl-CoA-specific types, such as resveratrol synthase (EC 2.3.1.95) and pinosylvin synthase (EC 2.3.1.146), which produce resveratrol and pinosylvin, respectively (Kodan et al. 2002; Chong et al. 2009). In the biosynthesis of stilbenes, three malonic acids are cyclized and added to cinnamoyl-CoA or $p$-coumaroyl-CoA by aldol-type 
<smiles>[R]c1ccc(/C=C/C(=O)S(=O)(=O)O)cc1[R]</smiles>

R3

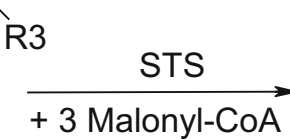

Cinnamoyl-CoA; R3=R4=H -Coumaroyl-CoA; R3=H, R4=OH Caffeoyl-CoA; R3=R4=OH

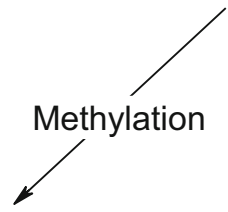

Pinosylvin monomethyl ether; $\mathrm{R} 1=\mathrm{OH}, \mathrm{R} 2=\mathrm{OMe}, \mathrm{R} 3=\mathrm{R} 4=\mathrm{H}$

Pinosylvin dimethyl ether; $\mathrm{R} 1=\mathrm{R} 2=\mathrm{OMe}, \mathrm{R} 3=\mathrm{R} 4=\mathrm{H}$

Glucosylation

Isorhapontigenin;

$\mathrm{R} 1=\mathrm{R} 2=\mathrm{R} 4=\mathrm{OH}, \mathrm{R} 3=\mathrm{OMe}$

Co<smiles>O=C(O)CCc1ccccc1</smiles><smiles>[R2]c1cc([R2])cc(CCc2ccccc2)c1</smiles>

$$
\text { PMT }
$$

Dihydropinosylvin monomethyl ether; $\mathrm{R} 1=\mathrm{OH} ; \mathrm{R} 2=\mathrm{OMe}$
Pinosylvin; R1=R2=OH, R3=R4=H

Resveratrol; R1-R2, R4=OH, R3=H

Piceatannol; R1-R4=OH

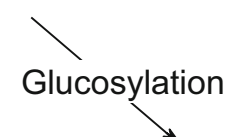

Piceid; R1=O-Glu, R2=R4=OH, R3=H

Astringin; R1=O-Glu, R2-R4=OH

Isorhapontin; R1=R4=OH, R3=OMe, R2=O-Glu

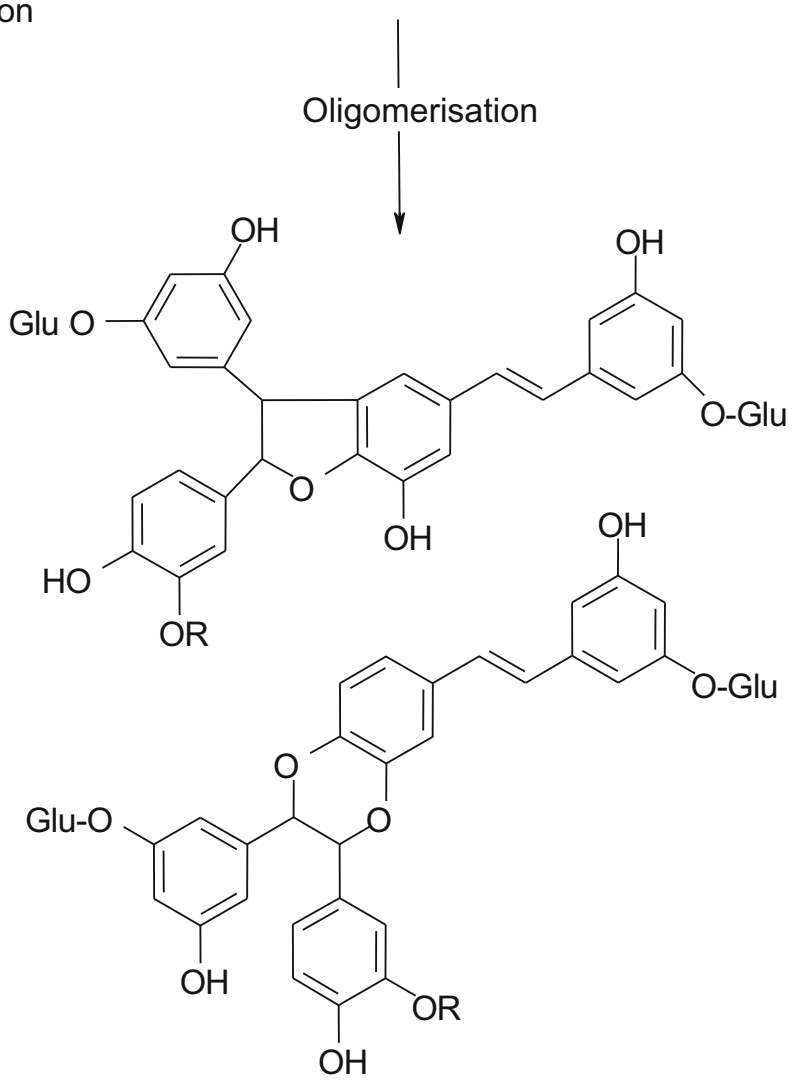

Chemical structures of piceasides $\mathrm{R}=\mathrm{H}$ or $\mathrm{Me}$ 
cyclization (C2 $\rightarrow$ C7) (Fig. 1) (Lim and Koffas 2010; Yu and Jez 2009; Flores-Sanchez and Verpoorte 2009).

In the Pinus genus, cinnamoyl-CoA is the major substrate when pinosylvins are the most abundant stilbenes (Gehlert et al. 1990; Zinser et al. 1998). Besides pinosylvin (3,5-dihydroxystilbene), the synthase enzyme is also able to catalyze the formation of dihydropinosylvin from dihydrocinnamoyl-CoA. It is not clear whether the same enzyme performs in both of these reactions or whether two different enzymes are involved (Fliegmann et al. 1992). In the Picea genus, $p$-coumaroyl-CoA is the major substrate, since the first step in stilbene biosynthesis is the formation of resveratrol. Further, it can be modified by hydroxylation, methoxylation and glucosylation to produce astringin $\left(3,3^{\prime}, 4^{\prime}, 5\right.$-tetrahydroxystilbene $3-O-\beta$-D-glucoside) and isorhapontin (3,4',5-trihydroxy- $3^{\prime}$ methoxystilbene 3-O- $\beta$-D-glucoside) (Hammerbacher et al. 2011; Grunwald 2017).

Methylation of hydroxyl groups in phenyl compounds can lead to increased biological activity of stilbenes (Pezet et al. 2004). It is also observed that under stress conditions the pinosylvin-3-O-methyltransferase enzyme catalyses the conversion of pinosylvin to monomethyl ether. Particularly, the ether form is observed in Scots pine ( $P$. sylvestris) rather than in Norway spruce (P. abies) (Chiron et al. 2000).

Pinosylvin-3-O-methyltransferase is not a very specific enzyme towards pinosylvin, which is why the enzyme may convert also other stilbenes, flavonoids, and simple phenolic compounds (Sandermann et al. 2000). In addition, substitution reaction can occur in both rings of the structure (Fig. 1): the A ring usually has two hydroxyl groups in the meta position, while the B ring is substituted by hydroxyl and methyl groups in the ortho, meta and/or para positions (Cassidy et al. 2000). In Scots pine, only the A ring substitution has been observed. UV-light can also convert the polyphenolic pinosylvin structures by configurational isomerism. Photosynthesis has been observed to activate the formation of the stereoisomer of cis-stilbene. The extension reaction of trans-cis isomerization produces phenanthrene, which is a polycyclic aromatic hydrocarbon (PAH) (Kwasniewski et al. 2003).

The defensive role of stilbenes in conifers is well known. Due to their antimicrobial properties, the accumulation of large amounts of pinosylvin and pinosylvin 3-O-methyl ether prevents the wood from decay by microorganisms in the heartwood. It is known that stilbenes pre-exist in wood naturally, generally in glycosylated forms, and stilbenes that are synthesized after microbial attack are in the free aglycone form (Chong et al. 2009). Glycosylation of stilbenes is postulated to protect plant cells from toxic effects and to protect stilbenes from oxidation and enzymatic degradation (Hipskind and Paiva 2000).

\section{Stilbenes in Scots pine (Pinus sylvestris) and their antimicrobial activity}

In the sapwood, phloem, and needles of Scots pine ( $P$. sylvestris) stilbenes accumulate in the tree to defend biotic stress after wounding, fungal attack, and ozone intake, which increases the amount of oxygen in the wood and enables the compound reactions chemically with oxygen (Gehlert et al. 1990; Zinser et al. 1998; Rosemann et al. 1991). Stilbene contents in air-dry wood have been reported to be $0.2-2 \%$ in heartwood and $2-8 \%$ in knots of Scots pine (P. sylvestris) (Willför et al. 2003c; Venäläinen et al. 2004; Hovelstad et al. 2006). The highest concentrations have been observed in old trees ( 87 years old) and at the lower part of the stems (Hovelstad et al. 2006). Pinosylvin and pinosylvin monomethyl ether are the most abundant stilbenes in Scots pine; the other derivatives pinosylvin dimethyl ether and dihydropinosylvin and its methylated analogue are detected in smaller abundance (Venäläinen et al. 2004; Hovelstad et al. 2006; Välimaa et al. 2007; Pietarinen et al. 2006; Lindberg et al. 2004).

Hydrophilic extracts of Scots pine ( $P$. sylvestris) have been observed to contain $22 \%$ pinosylvin and $16 \%$ pinosylvin monomethyl ether (Pietarinen et al. 2006). Pinosylvin and monomethyl pinosylvin have been noticed to have anti-inflammatory properties, since they reduce inflammatory gene expression and inflammatory responses in vivo (Laavola et al. 2015).

Pinosylvin is suggested to be synthetized in plants from cinnamic acid by ozone exposure under UV radiation or fungal attack (Chiron et al. 2000, 2001). The pinosylvin products have been identified in knotwood extracts and are assumed to be significant compounds for induced resistance in Scots pine $(P$. sylvestris) (Gehlert et al. 1990; Laavola et al. 2015). 
Stilbenes can undergo photocyclization and photoisomerization processes. Especially, (Z)-stilbene may undergo electrocyclic reactions, which help its conjugation and chemical affinity to toxic ligands. The precise mechanism of the antibacterial action of stilbenes is unclear. One possibility is that they destroy the membrane structure, resulting in a bursting of the cell (Nitta et al. 2002). It is suggested that especially the two hydroxyl groups in the meta position of the aromatic ring, and the double bond in the carbon chain between the rings play important roles (Välimaa et al. 2007).

Strong inhibitory effects against the growth of the Gram-positive human pathogens Bacillus cereus, $S$. aureus, and Listeria monocytogenes have been reported (Table 1). Clear inhibition of the Gramnegative bacteria E. coli, Salmonella infantis, and Pseudomonas fluorescens was observed (Table 2, Välimaa et al. 2007). The major antibacterial compounds of the knotwood extract of pine, have been found to act against the paper mill bacteria Burkholderia multivorans, Alcaligenes xylosoxydans, and Bacillus coagulans (Lindberg et al. 2004).

Stilbenes have been extensively studied for their fungi-conifer interactions. A common response to wounds or fungal attack is a decrease in glycosylation (Viiri et al. 2001; Malá et al. 2011; Lieutier et al. 2003; Cvikrová et al. 2008). The concentrations of stilbene glucosides in the inner bark of Scots pine $(P$. sylvestris) have been observed to decrease more in the vicinity of fungal inoculation than in the vicinity of mechanical damage (Viiri et al. 2001; Jyske et al. 2014). On the other hand, the concentrations of the corresponding stilbene aglycones have been found to be elevated only near the fungal inoculation sites (Viiri et al. 2001).

\section{Stilbenes in Norway spruce (P. abies) and their antibacterial activity}

Spruce bark has been found to contain high concentrations of several stilbene glucosides and their aglycons, lignans, flavonoids and tannins. In Norway spruce ( $P$. abies) the bioactive hydroxylated stilbene derivatives (stilbenoids) are located within phloem and bark (Jyske et al. 2014). The current understanding on the biosynthesis, distribution, and localization of stilbenes is still fragmentary. However, the metabolites have similar multiple biological activities as those in pine, such as protection against environmental stresses, as well as antifungal and antimicrobial functions (Harju et al. 2003; Willför et al. 2003a, b, c).

Three stilbene glucosides; piceid, isorhapontin, and astringin, and the corresponding aglycones; resveratrol (trans-3,5,4'-trihydroxystilbene, Fig. 1), isorhapontigenin (an analogue of resveratrol), and piceatannol (a metabolite of resveratrol) have been found in different wood parts. Astringin and isorhapontin are the most abundant in sapwood and bark (Viiri et al. 2001; Zeneli et al. 2006; Danielsson et al. 2011; Malá et al. 2011). In phenolic extracts their proportions vary considerably, in studies of the inner and outer phloem and bark. It was assumed that the reason was their metabolic activity. Normalized concentrations of $72 \%, 20 \%$, and $5 \%$ were detected for isorhapontin, astringin, and piceid from sapwood (Zeneli et al. 2006). On the contrary, when the bark was dry, astringin and isorhapontin concentrations were $0.5 \%-6 \%$ of its dry weight (dw) (Viiri et al. 2001; Solhaug 1990). Contrary to that, the similar extracts from the bark were reported to contain even $47 \%, 39 \% 8 \%$, and $0.4 \%$ isorhapontin, astringin, piceid, and piceatannol, respectively (Zeneli et al. 2006). Analogically, stilbene glucosides have mainly been localised in the inner bark (phloem) of the wood (Solhaug 1990), which has been found to contain $0.7-0.8 \%$ of the above-mentioned glycosides and $\sim 0.05 \%$ resveratrol in fresh material (wet weight) (Viiri et al. 2001). However, the amount of stilbene glucosides in the mixture is high: when extracted from bark of Norway spruce (P. abies), one cubic meter ( $\sim 450 \mathrm{~kg}$ as the air-dry weight) of the spruce timber may provide $1.6 \mathrm{~kg}$ of various kinds of stilbenes that is $\sim 0.4 \%$ of the air-dry weight (Jyske et al. 2014). Naturally, the purification of the individual compounds requires specific and sensitive methods.

Isorhapontigenin, that is an isomer of rhapontigenin and an analogue of resveratrol (Danielsson et al. 2011) and the stilbene glucoside dimers of piceid ( $\mathrm{Li}$ et al. 2008) have been found to exist in extracts of Norway spruce ( $P$. abies) bark. The early discoveries showed that isorhapontin (the glucoside of isorhapontigenin) could be detected in roots (Münzenberger et al. 1990) and root bark (Pan and Lundgren 1995). Piceaside and piceatannol could be isolated from the other stilbenes detected in roots (Münzenberger et al. 1990) while piceid and astringin have been shown to exist in root 
Table 1 Selection of the most active antibacterial compounds and extracts from Scots pine and/or Norway spruce (MIC values of $\leq 300 \mathrm{mg} / \mathrm{L})$

\begin{tabular}{|c|c|c|}
\hline \multirow{2}{*}{$\begin{array}{l}\text { Compounds in extracts and isolated } \\
\text { solutions }\end{array}$} & \multicolumn{2}{|l|}{ Antibacterial activity } \\
\hline & Gram-positive bacteria & Gram-negative bacteria \\
\hline \multicolumn{3}{|l|}{ Stilbenes } \\
\hline Pinosylvin & $\begin{array}{l}\text { B. cereus } 101 \pm 6 \% \text { inhibition/ } \\
106 \mathrm{mg} \mathrm{L}^{-1} \text { (Välimaa et al. 2007) }\end{array}$ & \\
\hline Pinosylvin monomethyl ether & $\begin{array}{l}\text { S. aureus } 105 \pm 12 \% \text { inhibition/ } \\
113 \mathrm{mg} \mathrm{L}^{-1} \text { (Välimaa et al. 2007) } \\
\text { L. monocytogenes } 100 \pm 7 \% \text { inhibition/ } \\
113 \mathrm{mg} \mathrm{L}^{-1} \text { (Välimaa et al. 2007) }\end{array}$ & \\
\hline Resveratrol & $\begin{array}{l}\text { B. cereus MIC } 50 \mathrm{mg} \mathrm{L}^{-1} \text {, E. faecalis, } \\
\text { MIC } 50-200 \mathrm{mg} \mathrm{L}^{-1} \text { and } S \text {. aureus MIC } \\
100-200 \mathrm{mg} \mathrm{L}^{-1} \text { (Paulo et al. 2010) }\end{array}$ & $\begin{array}{l}\text { H. pylori MIC varying from } 25 \text { to } 100 \mathrm{mg} \mathrm{L}^{-1} \text { (Paulo } \\
\text { et al. 2010) }\end{array}$ \\
\hline
\end{tabular}

\section{Flavanones}

Pinocembrin

Dihydroflavonols

Taxifolin-7-O-rhamnopyranoside

Aromadendrin-7-O-rhamnopyranoside

Pinobanksin3-acetate

Flavonols

Quercetin

3-O-methylquercetin

Acylated kempferol-3-O-glucosides

Kaempferol-3-O-(2", $4^{\prime \prime}$-di-E- $p$-coumaroyl)rhamnoside and kaempferol-3- $O-\left(2^{\prime \prime}-\mathrm{Z}-\mathrm{p}-\right.$ coumaroyl, $4^{\prime \prime}$-E- $p$-coumaroyl)-rhamnoside

Myricetin

Flavones

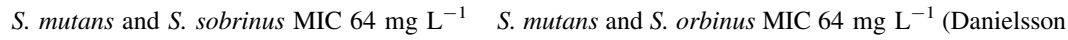
(Danielsson et al. 2011) et al. 2011)

MRSA MIC 32-64 $\mathrm{mg} \mathrm{L}^{-1}$ and MBC 64-128 $\mathrm{mg} \mathrm{L}^{-1}$ (Bastianetto et al. 2015)

MRSA MIC 64-128 $\mathrm{mg} \mathrm{L}^{-1}$ and MBC $128-512 \mathrm{mg} \mathrm{L}^{-1}$ (Bastianetto et al. 2015)

S. mutans MIC $157 \mathrm{mg} \mathrm{L}^{-1}$ (Koo et al. 2002)

S. sobrinus MIC $79 \mathrm{mg} \mathrm{L}^{-1}$ (Koo et al. 2002)

S. aureus MIC $6.25 \mathrm{mg} \mathrm{L}^{-1}$ (van Puyvelde et al. 1989)

B. subtilis MIC $50 \mathrm{mg} \mathrm{L}^{-1}$ (van Puyvelde et al. 1989)

M. smegmatis, and S. pyogenes MIC $100 \mathrm{mg} \mathrm{L}^{-1}$ (van Puyvelde et al. 1989)

B. cereus MIC $4-16 \mathrm{mg} \mathrm{L}^{-1}$ (Liu et al. 1999)

S. epidermidis MIC 2-64 $\mathrm{mg} \mathrm{L}^{-1}$ (Liu et al. 1999)

S. aureus MIC $16-64 \mathrm{mg} \mathrm{L}^{-1}$ (Liu et al. 1999)

M. luteus MIC $8-16 \mathrm{mg} \mathrm{L}^{-1}$ (Liu et al. 1999)

MRSA MIC $0.5-2 \mathrm{mg} \mathrm{L}^{-1}$ (Otsuka et al. 2008)

E. faecalis MIC $4 \mathrm{mg} \mathrm{L}^{-1}$ (Otsuka et al. 2008)

E. faecium MIC $8 \mathrm{mg} \mathrm{L}^{-1}$ (Otsuka et al. 2008)

MRSA, MIC $128 \mathrm{mg} \mathrm{L}^{-1}$ (Xu and Lee 2001)

VRE MIC $128 \mathrm{mg} \mathrm{L}^{-1}$ (Xu and Lee 2001)
H. pylori $\mathrm{MBC}<200 \mathrm{mg} \mathrm{L}^{-1}$ (Martini et al. 2009)

S. typhimurium MIC $50 \mathrm{mg} \mathrm{L}^{-1}$ (van Puyvelde et al. 1989)

E. cloaceae, E. coli, K. pneumoniae, $P$. vulgaris, $P$. aeruginosa and $P$. solanacearum, $S$. marcescens, $S$. dynasteriae MIC $100 \mathrm{mg} \mathrm{L}^{-1}$ (van Puyvelde et al. 1989)

B. cepacia, MIC $32 \mathrm{mg} \mathrm{L}^{-1}$ (Xu and Lee 2001) 
Table 1 continued

\begin{tabular}{|c|c|c|}
\hline \multirow{2}{*}{$\begin{array}{l}\text { Compounds in extracts and isolated } \\
\text { solutions }\end{array}$} & \multicolumn{2}{|l|}{ Antibacterial activity } \\
\hline & Gram-positive bacteria & Gram-negative bacteria \\
\hline Apigenin & $\begin{array}{l}\text { B. subtilis MIC } 110 \mathrm{mg} \mathrm{L}^{-1} \text { (Öksüz et al. } \\
\text { 1984) }\end{array}$ & $\begin{array}{l}\text { E. aerugenes and E. cloaceae MIC } 4 \mathrm{mg} \mathrm{L}^{-1} \text { (Basile } \\
\text { et al. 1999) } \\
\text { P. aeruginosa MIC } 8 \mathrm{mg} \mathrm{L}^{-1} \text { (Basile et al. 1999) } \\
\text { P. mirabilis MIC } 16 \mathrm{mg} \mathrm{L}^{-1} \text { (Basile et al. 1999) } \\
\text { P. vulgaris MIC } 55 \mathrm{mg} \mathrm{L}^{-1} \text { (Öksüz et al. 1984) } \\
\text { P. aeruginosa and E. coli MIC } 110 \mathrm{mg} \mathrm{L}^{-1} \text { (Öksüz } \\
\text { et al. 1984) } \\
\text { K. pneumoniae, S. typhi and E. coli MIC } 128 \mathrm{mg} \mathrm{L}^{-1} \\
\text { (Basile et al. 1999) }\end{array}$ \\
\hline 6-Methoxyapigenin & $\begin{array}{l}\text { B. subtilis MIC } 125 \mathrm{mg} \mathrm{L}^{-1} \text { (Öksüz et al. } \\
\text { 1984) }\end{array}$ & P. vulgaris MIC $125 \mathrm{mg} \mathrm{L}^{-1}$ (Öksüz et al. 1984) \\
\hline \multicolumn{3}{|l|}{ Simple phenols } \\
\hline Protocatechuic acid & $\begin{array}{l}\text { L. monocytogenes, S. aureus and B. cereus, } \\
\text { MIC } 24-44 \mathrm{mg} \mathrm{L}^{-1} \text { (Chao and Yin } \\
\text { 2009) } \\
\text { B. cereus MIC } 100 \mathrm{mg} \mathrm{L}^{-1}, \mathrm{MBC} \\
200 \mathrm{mg} \mathrm{L}^{-1} \text { (Ćirić et al. 2011) } \\
\text { M. flavus, S. aureus and L. monocytogenes } \\
\text { MIC } 200 \mathrm{mg} \mathrm{L}^{-1}, \mathrm{MBC} 400 \mathrm{mg} \mathrm{L}^{-1} \\
\text { (Chao and Yin 2009) }\end{array}$ & $\begin{array}{l}\text { S. typhimurium and E. coli, MIC } 24-44 \mathrm{mg} \mathrm{L}^{-1} \text { (Chao } \\
\text { and Yin 2009) } \\
\text { P. aeruginosa and S. typhimurium MIC } 100 \mathrm{mg} \mathrm{L}^{-1} \text {, } \\
\text { MBC } 200 \mathrm{mg} \mathrm{L}^{-1} \text { (Ćirić et al. 2011) } \\
\text { E. coli MIC and MBC } 200 \mathrm{mg} \mathrm{L}^{-1} \text { (Chao and Yin } \\
\text { 2009) } \\
\text { P. mirabilis MIC } 200 \mathrm{mg} \mathrm{L}^{-1}, \mathrm{MBC}^{-} 400 \mathrm{mg} \mathrm{L}^{-1} \\
\text { (Chao and Yin 2009) }\end{array}$ \\
\hline Gallic acid & $\begin{array}{l}\text { S. aureus, MIC } 3.5-12.5 \mathrm{mg} \mathrm{L}^{-1} \text { (Al- } \\
\text { Zahrami 2012) } \\
\text { S. aureus and S. epidermidis MIC } \\
\quad 31 \mathrm{mg} \mathrm{L}^{-1} \text { (Silva et al. 2010) } \\
\text { S. haemolyticus MIC } 62 \mathrm{mg} \mathrm{L}^{-1} \text { (Silva } \\
\text { et al. 2010) }\end{array}$ & $\begin{array}{l}\text { P. mirabilis } \mathrm{MIC} 62 \mathrm{mg} \mathrm{L}^{-1} \text { (Silva et al. 2010) } \\
\text { E. coli } \mathrm{MIC} 125 \mathrm{mg} \mathrm{L}^{-1} \text { (Silva et al. 2010) }\end{array}$ \\
\hline Gallic acid methyl ester & $\begin{array}{l}\text { S. aureus, MIC } 3.5-12.5 \mathrm{mg} \mathrm{L}^{-1} \text { (Al- } \\
\text { Zahrami 2012) }\end{array}$ & \\
\hline Picein & $\begin{array}{l}\text { B. cereus and E. faesalis MIC } 16 \mathrm{mg} \mathrm{L}^{-1} \\
\text { (Sarıahya et al. 2011) } \\
\text { S. aureus MIC } 64 \mathrm{mg} \mathrm{L}^{-1} \text { (Sarıkahya et al. } \\
\text { 2011) }\end{array}$ & $\begin{array}{l}\text { S. typhimurium, E. coli and } P \text {. aeruginosa } \mathrm{MIC} \\
32 \mathrm{mg} \mathrm{L}^{-1} \text { (Sarkahya et al. 2011) } \\
\text { K. pneumoniae MIC } 64 \mathrm{mg} \mathrm{L}^{-1} \text { (Sarkkahya et al. } \\
\text { 2011) }\end{array}$ \\
\hline$p$-Coumaric acid & $\begin{array}{l}\text { S. aureus, B. subtilis and S. pneumonia, } \\
\text { MIC } 20 \mathrm{mg} \mathrm{L}^{-1} \text { (Lou et al. 2012) }\end{array}$ & $\begin{array}{l}\text { S. dysenteriae and S. typhimurium, MIC } \\
10-20 \mathrm{mg} \mathrm{L}^{-1} \text { (Lou et al. 2012) } \\
\text { E. coli, MIC } 80 \mathrm{mg} \mathrm{L}^{-1} \text { (Lou et al. 2012) }\end{array}$ \\
\hline \multicolumn{3}{|l|}{ Lignans } \\
\hline (+)-Lariciresinol 4'-O-glucopyranoside & $\begin{array}{l}\text { S. epidermidis, MIC } 25 \mathrm{mg} \mathrm{L}^{-1} \text { (Wan et al. } \\
\text { 2012) } \\
\text { S. aureus, MIC } 50 \mathrm{mg} \mathrm{L}^{-1} \text { (Wan et al. } \\
\text { 2012) }\end{array}$ & \\
\hline
\end{tabular}

bark only (Pan and Lundgren 1995). Needles of Norway spruce ( $P$. abies) contain astringin and isorhapontin as well as piceatannol (its glucoside is astringin) at $0.2-2 \%$ (Solhaug 1990) and $0.4 \%$ from dw (Turtola et al. 2006), respectively.

Resveratrol (Fig. 1) is one of the most extensively studied natural products due to its beneficial health properties, including anti-ageing, anticancer, antioxidant, anti-inflammatory, antiviral, cardioprotective, and neuroprotective effects (Lim and Koffas 2010; Szekeres et al. 2010; Bastianetto et al. 2015). However, its antibacterial activity has been less studied. Resveratrol exhibits activity against Grampositive human pathogenic bacteria $B$. cereus, $S$. aureus, and Enterococcus faecalis with minimum inhibiting concentrations (MIC) of $50-200 \mathrm{mg} \mathrm{L}^{-1}$ 


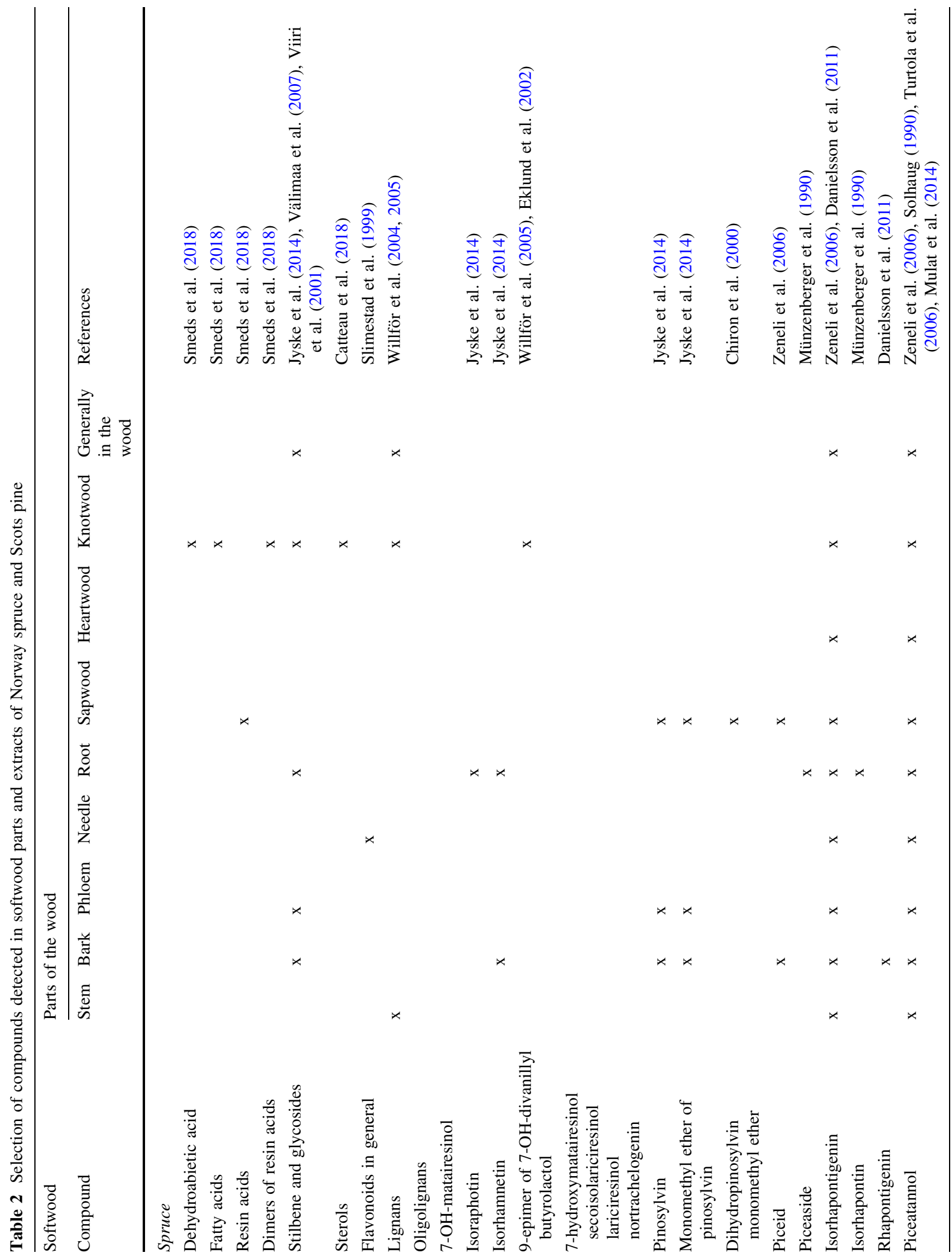




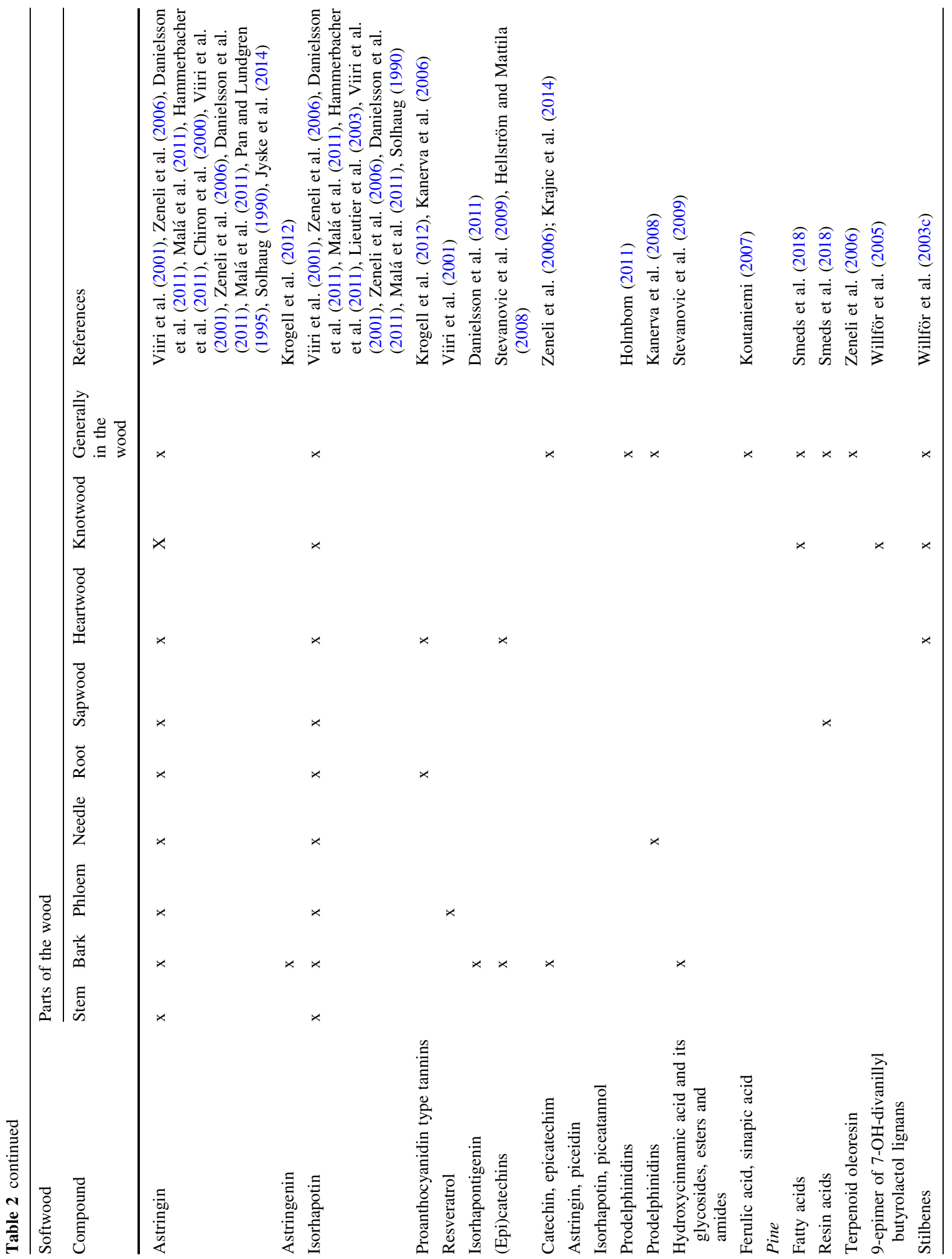




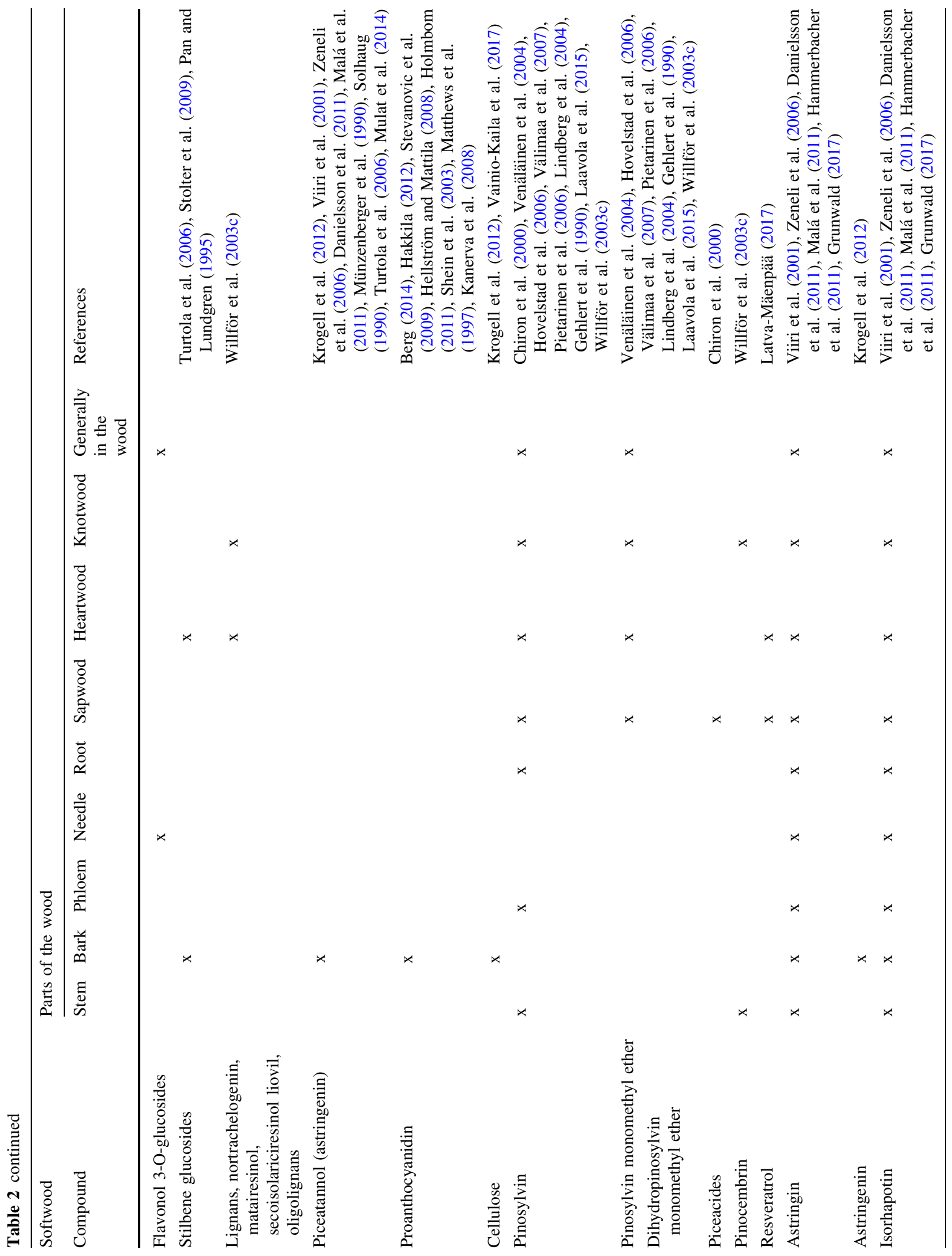




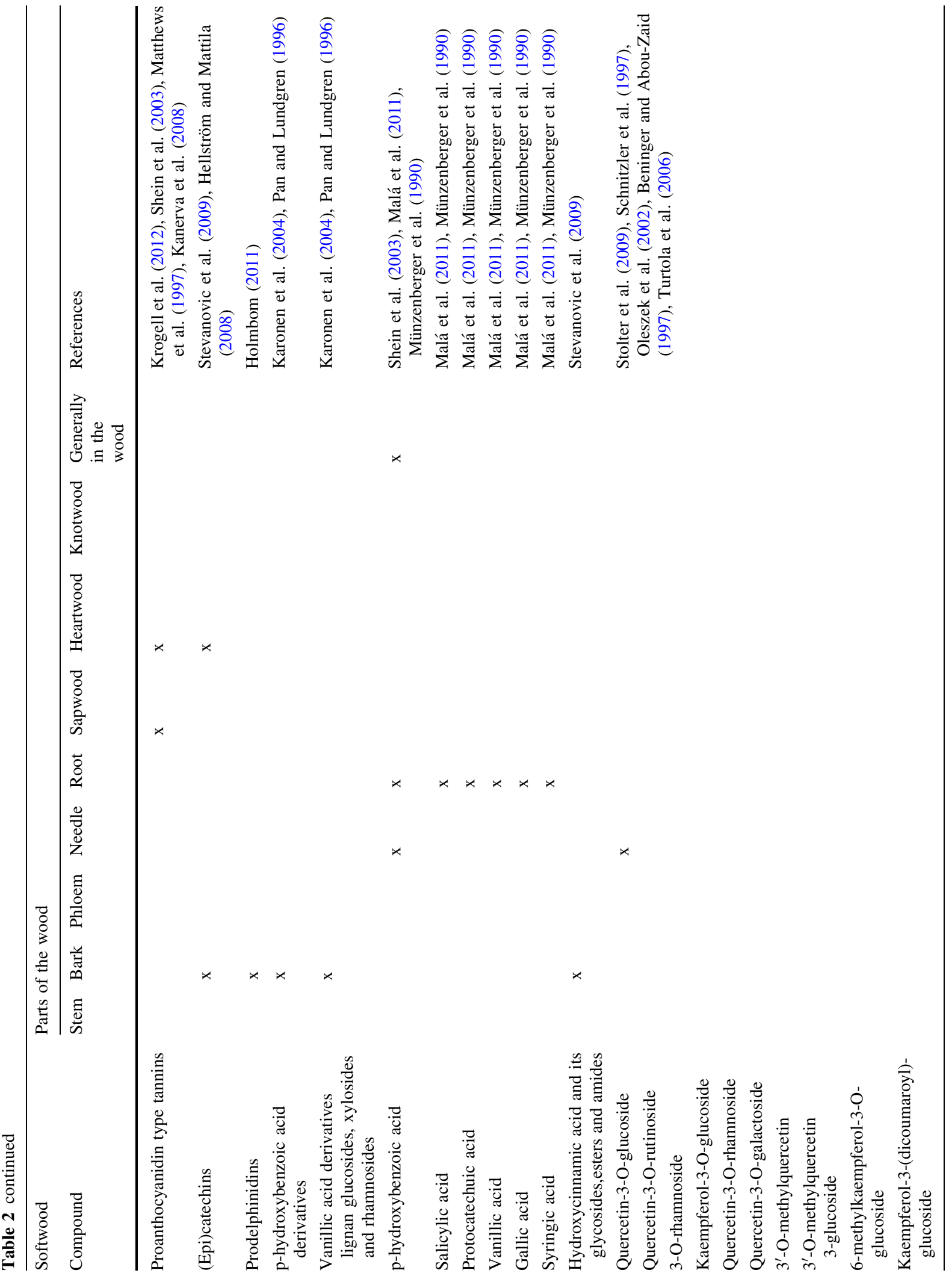




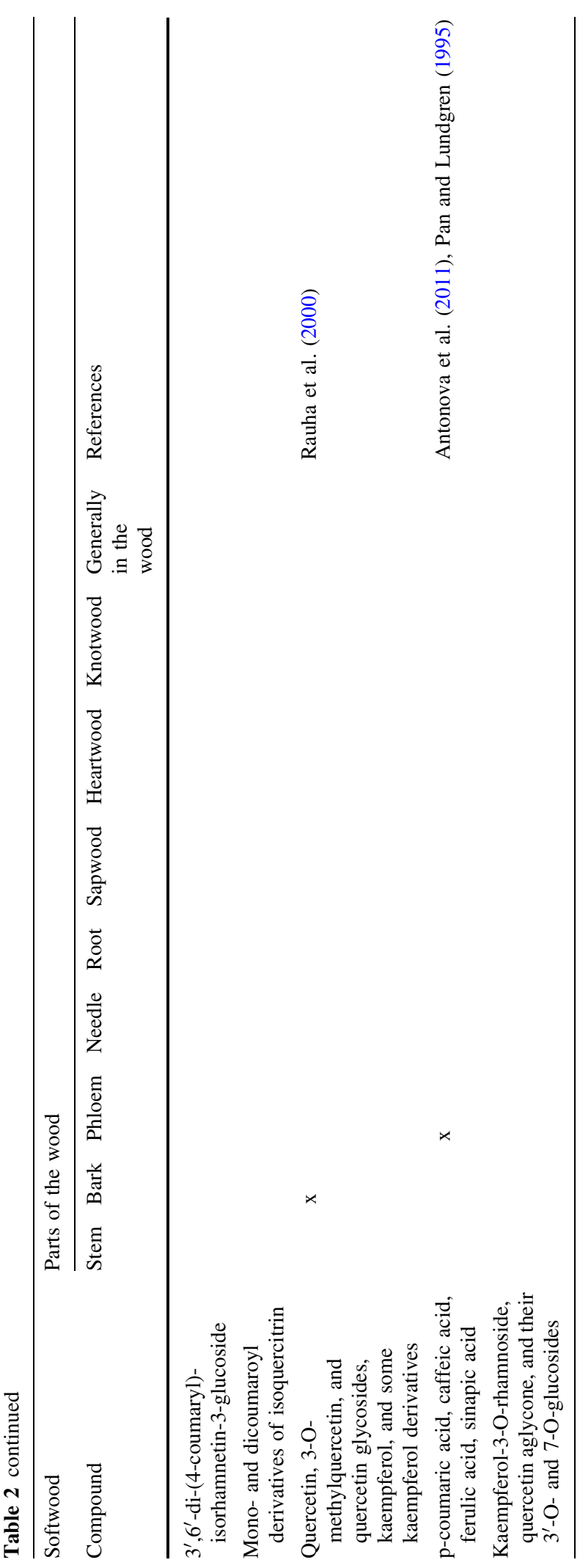


(Paulo et al. 2010). It is less active against Gramnegative bacteria, E. coli, Klebsiella pneumoniae and Salmonella typhimurium than the Gram-positive bacteria being inactive against Pseudomonas aeruginosa (Table 1). In another study, resveratrol has been tested against different strains of Helicobacter pylori resulting in the MIC values of $25-100 \mathrm{mg} \mathrm{L}^{-1}$ (Paulo et al. 2011). The experiments also showed an inhibitory effect on $H$. pylori urease, which is essential for the colonialization and establishment of infections. Resveratrol and its glucoside conjugate piceid were also studied against three Gram-positive bacteria ( $B$. cereus, L. monocytogenes, and $S$. aureus) and two Gram-negative bacteria (E. coli, Salmonella anatum) (Shan et al. 2008). In general, both the aglycone and the glucoside appeared to show similar bioactivity resulting in the MIC values of $313 \mathrm{mg} \mathrm{L}^{-1}$ for $S$. aureus and $S$. anatum and $625 \mathrm{mg} \mathrm{L}^{-1}$ for L. monocytogenes. Regardless, resveratrol was more efficient against $B$. cereus and $E$. coli (MIC $313 \mathrm{mg} \mathrm{L}^{-1}$ ) than piceid (MIC $625 \mathrm{mg} \mathrm{L}^{-1}$ ). Listeria monocytogenes, $S$. aureus, E. coli, and $S$. anatum had the same bacteriostatic concentration of $625 \mathrm{mg} \mathrm{L}^{-1}$, whereas that of $B$. cereus was even $2500 \mathrm{mg} \mathrm{L}^{-1}$ for resveratrol (Shan et al. 2008).

Trans-isorhapontin and trans-astringin have been identified as the major, and trans-piceid as the minor stilbene glucosides from the rootbark of Norway spruce (P. abies) (Jyske et al. 2014). Not only stilbene glucosides but also the corresponding stilbene aglycones, such as trans-resveratrol, trans-piceatannol and trans-isorhapontigenin, have been identified from hydrolysed extracts of spruce bark (Mulat et al. 2014). Lately, it has been confirmed that the hydroxylated stilbene glucosides trans-astringin and transisorhapontin are the major compounds, and that trihydroxystilbene trans-piceid is the minor compound in the roots of Norway spruce ( $P$. abies) (Holmbom 2011; Venäläinen et al. 2004). In addition, the aglycones of stilbene glucosides (Holmbom 2011; Hovelstad et al. 2006) and several dimers of stilbene glucosides have been identified in the extracts of the roots (Välimaa et al. 2007).

\section{Flavonoids from Norway spruce and Scots pine}

Biosynthesis of flavonoids

Biosynthetic pathways (Lim and Koffas 2010; Winkel-Shirley 2001) of different flavonoid subclasses in plants are shown in Fig. 2. Chalcone synthase (CHS, EC 2.3.1.74) is the first enzyme in the flavonoid pathway. The CHS is an enzyme confined to higher plants and belongs to a family of polyketide synthase enzymes (PKS) known as type III PKS (Fig. 2). It uses three malonyl-CoA substrates and one cinnamoylCoA or $p$-coumaroyl-CoA substrate, generating naringenin chalcone or pinocembrin chalcone, respectively, in a Claisen-type cyclisation reaction $(\mathrm{C} 6 \rightarrow \mathrm{C} 1)$ ( $\mathrm{Yu}$ and Jez 2009; Flores-Sanchez and Verpoorte 2009). Following these reactions, the chalcones are isomerized by chalcone isomerases (CHI, EC 5.5.1.6) to flavanones, from which naringenin and pinocembrin are precursors of flavones and dihydroflavonols.

Hydroxylation of flavanones at the 3 position of the C-ring by flavanone $3 \beta$-hydroxylase (EC 1.14.11.9, Fig. 2) leads to the formation of dihydroflavonols (He et al. 2008; El Sayed Bashandy 2016). Flavanones are converted to flavones by flavone synthase (FSI, EC 1.14.11.22, Fig. 2) and dihydroflavonols to flavonols by flavonol synthase (FLS, EC 1.14.11.23, Fig. 2) (Cheng et al. 2014). In these syntheses, a double bond is introduced between the carbons 2 and 3 at the A ring. Dihydroflavonol 4-reductase (DFR, EC 1.1.1.219, Fig. 2) catalyses the reduction of the carbonyl group at the 4 position to the hydroxyl group to give flavan-3,4-diols (leucoanthocyanidins) that are intermediates for the biosynthesis of flavan-3-ols, sometimes called flavanols or catechins, and anthocyanins (Jagannath and Crozier 2010). Next, leucoanthocyanidin reductase (LAR, EC 1.17.1.3, Fig. 2) or anthocyanidin synthase (ANS, EC 1.14.11.19, Fig. 2) converts flavan-3,4-diols into flavan-3-ols or anthocyanidins, respectively. Finally, anthocyanidins are further converted to anthocyanins (i.e. glycosylated anthocyanidins) with UDP-D-glucose:anthocyanidin 3-O- $\beta$-D-glucosyl transferase (EC 2.4.1.115).

\section{Methylation and acylation of flavonoids}

The hydroxyl groups of flavonoids are prone to undergo methylation or glycosylation (Fig. 1). 


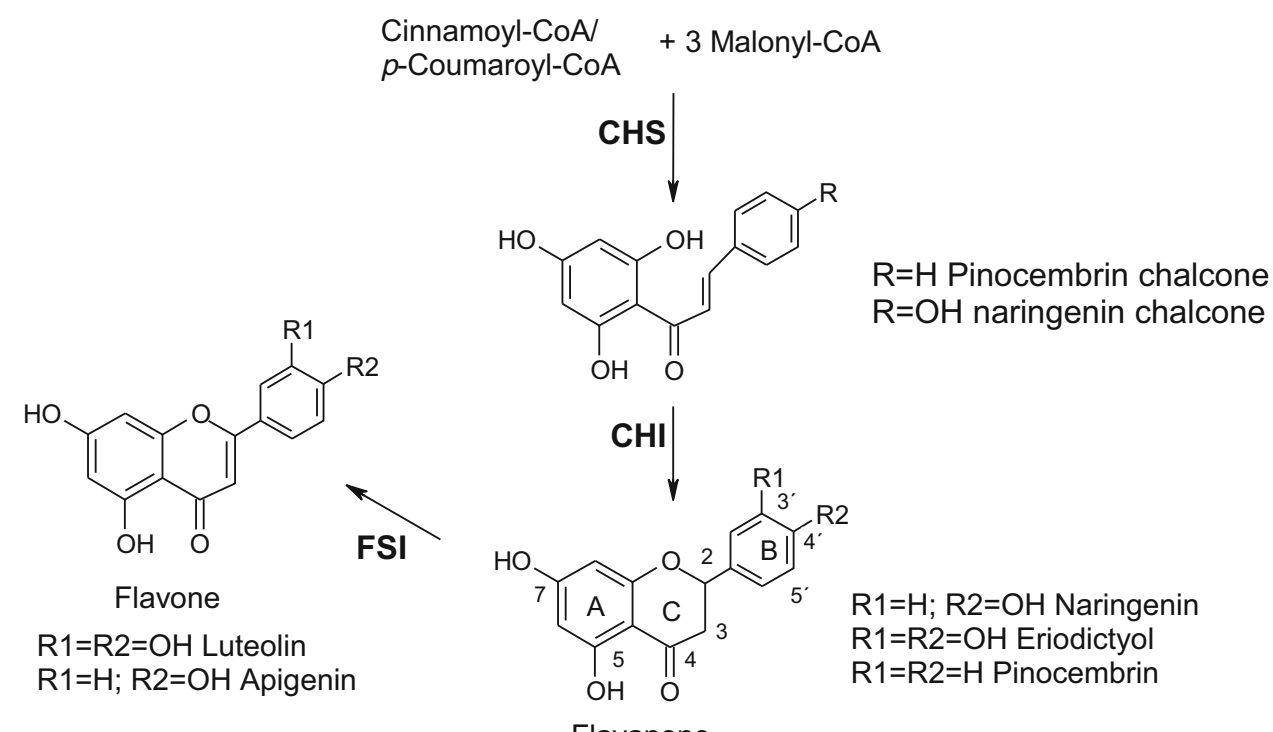

Flavanone<smiles>[R2]c1cc(C2Oc3cc(O)cc(O)c3C(=O)C2O)cc([R2])c1O</smiles>

FLS

Dihydroflavonol

$\mathrm{R} 1=\mathrm{R} 2=\mathrm{H}$ Dihydrokaempferol

$\mathrm{R} 1=\mathrm{OH} ; \mathrm{R} 2=\mathrm{H}$ Dihydroquercetin

$\mathrm{R} 1=\mathrm{R} 2=\mathrm{OH}$ Dihydromyricetin<smiles>[R2]c1cc([R14](=O)C([R])C)cc([R1])c1O</smiles>

Flavan-3,4-diol

(Leucoanthocyanidin)

$\mathrm{R} 1=\mathrm{R} 2=\mathrm{H}$ Kaempferol $\mathrm{R} 1=\mathrm{R} 2=\mathrm{OH}$ Myricetin $\mathrm{R} 1=\mathrm{OH} ; \mathrm{R} 2=\mathrm{H}$ Quercetin<smiles></smiles>

Anthocyanidins

$\mathrm{R} 1=\mathrm{R} 2=\mathrm{H}$ Pelargonidin $\mathrm{R} 1=\mathrm{OH} ; \mathrm{R} 2=\mathrm{H}$ Cyanidin $\mathrm{R} 1=\mathrm{R} 2=\mathrm{OH}$; Delphinidin<smiles>O=C1c2c(O)cc(O)cc2OC(c2ccccc2)C1O</smiles>

Pinobanksin<smiles>[R]c1cc(C2Oc3cc(O)cc(O)c3CC2O)cc(O)c1O</smiles>

Flavan-3-ol $\mathrm{R}=\mathrm{H}(+)$-Catechin $\mathrm{R}=\mathrm{OH}(+)-$ Gallocatechin

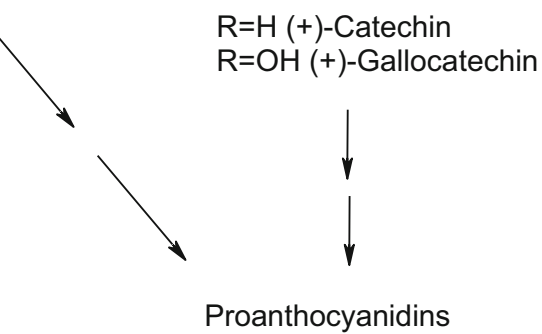

Proanthocyanidins 
4Fig. 2 Flavonoid biosynthesis. ANS anthocyanidin synthase; CHI chalcones isomerase; $C H S$ chalcone synthase; $D F R$ dihydroflavonol 4-reductase; $F 3^{\prime} H$ flavonoid $3^{\prime}$-hydroxylase; $F 3 H$ flavanone $3 \beta$-hydroxylase; $F L S$ flavonol synthase; FSI flavone synthase; LAR leucoanthocyanidin reductase. Modified from the paper of Lim and Koffas (2010)

Methylation involves the transfer of the methyl group of $S$-adenosyl-L-methionine to the hydroxyl group of the flavonoid (Ibrahim et al. 1998; Kim et al. 2010). $O$ Methylation of flavonoids is catalyzed by $O$-methyltransferases (EC 2.1.1.6.x, Fig. 1). They can be used for the production of $O$-methylated flavonoids that have a particular biological activity (Kim et al. 2010). In particular, $O$-methylation of hydroxyl groups in flavonoids reduces their reactivity and increases their antimicrobial activity (Ibrahim et al. 1998). Several $O$ methylated flavonols and unconjugated flavanols (catechins) have been found in conifers.

The final step in the flavonol biosynthesis is acylation (Fig. 3, Kaffarnik et al. 2005), which is catalysed by enzymes that transfer the acyl group of hydroxycinnamic acid $\mathrm{CoA}$ esters to flavonol 3-Oglucosides. Three types of flavonol 3-O-glucoside hydroxycinnamoyl transferases (EC 2.3.1.x, Fig. 3) have been found in Scots pine ( $P$. sylvestris) needles. Preferentially acylation begins at position $6^{\prime \prime}$ followed by position $3^{\prime \prime}$ (Fig. 3). In Scots pine (P. sylvestris) and needles of Norway spruce ( $P$. abies) flavonol 3-Oglucosides can be esterified with ferulic or $p$-coumaric acid flavonol at positions 6" and $3^{\prime \prime}$ (Schnitzler et al. 1996; Kaffarnik et al. 2005). Thus, the new compounds are derived from carboxylic acids, in which the hydrogen group is replaced by a hydrocarbon group.

\section{Antimicrobial effects of various flavonoid subclasses}

Flavonoids appear widely in the plant kingdom in many plants and they are the largest phenolic group in nature (Lim and Koffas 2010). Flavonoids consist of a central three-ring structure, but the various subclasses differ from each other due to the centrally situated heterocyclic ring structure (C-ring), where the two benzene rings are linked together (Fig. 2). The majority of flavonoids are flower, fruit, or leaf pigments of different colours. It is suggested that the antibacterial activity of flavonoids is due to their ability to form complexes with extracellular and soluble proteins, to make complexes with bacterial cell walls (Cowan 1999), and to inhibit bacterial quorum-sensing signal receptors, enzymes, and toxins (Cushnie and Lamb 2010).

The structural diversity of flavonoid metabolites are easily hydroxylated and methylated in presence of catalytic enzymes in synthases, reductases, isomerases, and transferases reactions. Typical flavonoids are hydroxylated at the 5 and 7 positions of the A-ring, whereas hydroxyl and methoxyl group substitutions occur at the $3^{\prime}, 4^{\prime}$, or $5^{\prime}$ positions of the B-ring. Like stilbenes, individual flavonoids can occur as aglycones and glycosides. The preferred glycosylation site on the flavonoids is the 3 position, but the 7 position is the least favourable. Almost all, natural flavonoids exist as their $O$-glycoside or $C$-glycoside forms in plants. It seems as though $O$-glycosylation generally reduces the bioactivity of flavonoids. Nevertheless, lately it has been shown that the sugar addition to oxygen has enhanced certain types of biological benefits in food (Xiao 2017). Glucose is the most common sugar residue, but flavonoids with galactose or rhamnose residues also exist in Scots pine. Flavonoids are classified into several subgroups, depending on the carbonyl group on the carbon 4, the double bond between the carbon 2 and 3, the presence of the hydroxyl group on the carbon 3, and the location of the B ring. Six types of flavonoids (flavones, flavanones, dihydroflavonols, flavonols, and flavan-3ols, and anthocyanidins) occur in Norway spruce $(P$. abies) and Scots pine (P. sylvestris) trees.

\section{Flavanones from Norway spruce and Scots pine}

Two flavanones, naringenin, and eriodictyol, have been detected in both Scots pine ( $P$. sylvestris) and Norway spruce. Naringenin has hydroxyl groups attached at the 5, 7, and $4^{\prime}$ positions (Fig. 2). Naringenin-7-glucoside has been observed in needles of Norway spruce (P. abies) (Slimestad et al. 1999) and naringenin aglycone in needles of Scots pine $(P$. sylvestris) (Rauha et al. 2000). Naringenin has been reported to show strong inhibition against the Grampositive bacteria Micrococcus luteus, S. aureus, and Staphylococcus epidermidis. It also shows clear activity against $B$. subtilis and E. coli, and a slight activity against P. aeruginosa (Rauha et al. 2000). 


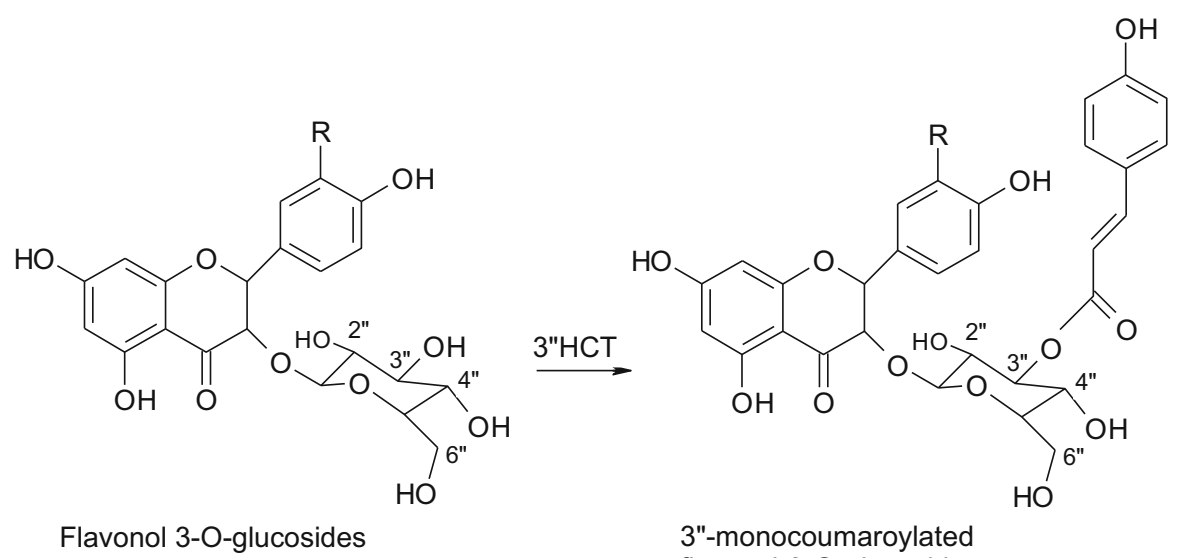

$\mathrm{R}=\mathrm{H}$, kaempferol

$\mathrm{R}=\mathrm{OH}$, guercetin

$\mathrm{R}=\mathrm{OMe}$, Isorhamnetin flavonol-3-O-glucosides

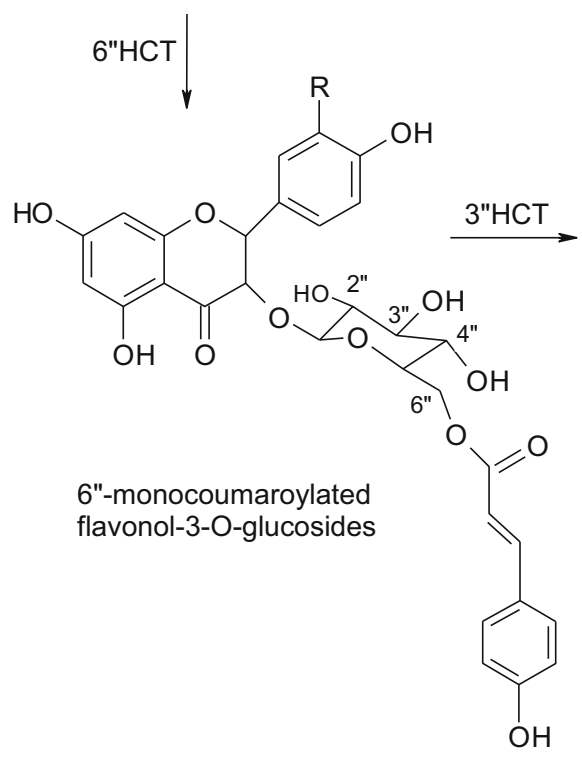

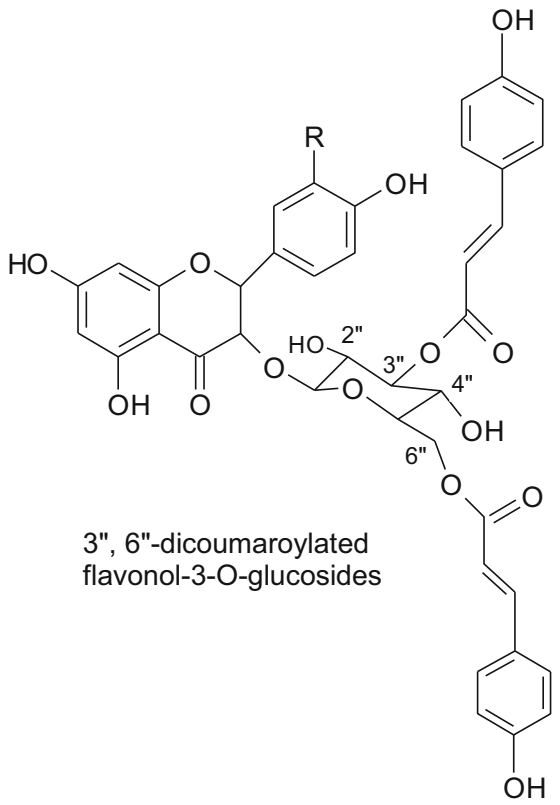

Fig. 3 Suggested acylation of flavonol-3-O-glucosides. HCT hydroxycinnamoyl-CoA flavonol 3-O-glucoside hydroxycinnamoyltransferase. Adapted from the paper of Kaffarnik et al. (2005)

First, it was published that naringenin could be isolated from Salix caprea (goat willow). Due to the purity of the extract the results ensured that naringenin has activity against E. coli, E. faecalis, and S. aureus (Malterud et al. 1985). Later the antibacterial activity of naringenin was also tested against methicillinresistant S. aureus (MRSA). At that time, it was verified that the MIC values were $200-400 \mathrm{mg} \mathrm{L}^{-1}$ (Tsuchiya et al. 1996).

Eriodictyol has hydroxyl groups at the 5, 7, $3^{\prime}$, and $4^{\prime}$ positions (Fig. 2). Usually, eriodictyol exists as 7'-
$O$-glucoside, but its $5^{\prime}$-glucoside has been detected in needles of Scots pine ( $P$. sylvestris) (Larsson et al. $1992)$ and the 7-O-glucoside only in needles of Norway spruce (P. abies) (Slimestad et al. 1999). Eriodictyol has the similar structure as naringenin, except of one additional hydroxyl group in the B-ring. It has been shown to be bioactive against several bacteria and it is a bitter-masking flavanone. The MIC values were $250 \mathrm{mg} \mathrm{L}^{-1}$ against $E$. coli and B. subtilis and $800 \mathrm{mg} \mathrm{L}^{-1}$ against Salmonella enterica, Pseudomonas putida, Listeria innocua, Lactococcus lactis, 
and S. aureus (Mandalari et al. 2007). Pinocembrin (Fig. 2) is an antioxidant that has hydroxyl groups only at the 5 and 7 positions of the A-ring, while the B-ring is unsubstituted. Pinocembrin and pinocembrin-7-methyl ether (pinostrobin) have frequently been found in Scots pine ( $P$. sylvestris) (Plant Metabolic Network 2012). They have been noticed to be present at dry weights below $0.02 \%$ (Willför et al. 2003c) in both stem wood and knots of branches and at $0.05 \%$ in fresh needles (Rosemann et al. 1991). Pinocembrin extracted from knotwood of pine (Pinus cembra) has shown to inhibit the growth of both Gram-positive (B. cereus, S. aureus, and L. monocytogenes) and Gram-negative (P. fluorescens, E. coli, and Streptococcus infantis) bacteria. The strongest activity has been observed against $B$. cereus (Wink 2003). The MIC values of $250 \mu \mathrm{M}\left(64.1 \mu \mathrm{gL}^{-1}\right)$ have been reported for commercial pinocembrin against Streptococcus mutans and Streptococcus sorbinus (Koo et al. 2002).

\section{Flavones from Norway spruce and Scots pine}

Apigenin (4',5,7-trihydroxyflavone, Fig. 2) and luteolin $\left(3^{\prime}, 4^{\prime}, 5,7\right.$-tetrahydroxyflavone, Fig. 2) are flavones from needles of Scots pine ( $P$. sylvestris) (Oleszek et al. 2002). Apigenin-7-glucoside has been found in the needles of both Scots pine (P. sylvestris) (Stolter et al. 2009) and Norway spruce (P. abies) (Slimestad et al. 1999).

Twenty years ago, Basile et al. (1999) noticed that apigenin isolated from mosses, inhibited the growth of several Gram-negative bacteria. However, it has not been observed to inhibit the growth of $S$. aureus nor $E$. faecalis which are Gram-positive bacteria. It was also reported that the MIC values were $4-128 \mathrm{mg} \mathrm{L}^{-1}$ against Proteus mirabilis, $P$. aeruginosa, Salmonella typhi, E. coli, Enterobacter aerogenes, Enterobacter cloaceae, and K. pneumoniae (Table 1). The MIC values for apigenin isolated from Centaurea species (e.g. common knapweed, Centaurea nigra), against $B$. subtilis, Klebsiella pneumonia, Proteus vulgaris, $P$. aeruginosa, and $E$. coli were higher, since they ranged from 55 to $219 \mathrm{mg} \mathrm{L}^{-1}$ (Öksüz et al. 1984). However, 6- $O$-methylapigenin showed activity only against $B$. subtilis and $P$. vulgaris, whereas luteolin has been reported to inhibit the growth of MRSA with the MIC value of $512 \mathrm{mg} \mathrm{L}^{-1}$ (Xu and Lee 2001).

\section{Flavonols in Scots pine (Pinus sylvestris)}

Needles of Scots pine ( $P$. sylvestris) trees characteristically contain kaempferol, quercetin, and their derivatives. Kaempferol has hydroxyl groups at the $4^{\prime}$ and 3 positions and quercetin at the $4^{\prime}, 5^{\prime}$ and 3 positions (Fig. 3). Mostly, they exist in their glycoside forms and the glucose groups have been identified to be bonded at the 3 position. For example, kaempferol3-O-glucoside (astragalin) and 3-O-rhamnoside (afzelin) (Stolter et al. 2009; Schnitzler et al. 1997), quercetin-3-O-glucoside (isoquercitrin), and quercetin-3-O-rutinoside (rutin) have been found in pine needles (Oleszek et al. 2002; Beninger and Abou-Zaid 1997). Quercetin-3-O-rhamnoside (quercitrin) and quercetin-3-O-galactoside (hyperocide) have been found in twigs including needles (Stolter et al. 2009). Although all the above-mentioned quercetins are glycosylated at the 3 position, it has also been reported that quercetin glucosides substituted at the $3^{\prime}$ position were dominant compounds (Oleszek et al. 2002). It has been suggested that $3^{\prime}-O$-glucosides of quercetin and taxifolin (dihydroflavonol) are crucial for protecting the plant from UV light (Oleszek et al. 2002). Hence, their amounts may depend on UV radiation.

Isorhamnetin (3'-O-methylquercetin), its 3 -glucoside, and 6-methylkaempferol-3-O-glucoside are commonly found as methylated compounds in Scots pine ( $P$. sylvestris) needles (Beninger and Abou-Zaid 1997). Acetylated flavonol 3-O-glucosides have also been frequently found (Turtola et al. 2006; Stolter et al. 2009; Pan and Lundgren 1995) and their concentrations have been reported to increase under UV radiation (Schnitzler et al. 1997). Glucosides of kaempferol, quercetin, and isorhamnetin can be acetylated at the $3^{\prime \prime}$ position with $p$-coumaric acid and at the 6 " position with either $p$-coumaric acid or ferulic acid (Kaffarnik et al. 2005). Kaempferol-3(dicoumaroyl)-glucoside (Stolter et al. 2009; Schnitzler et al. 1997) and 3',6'-di-(4-coumaryl)-isorhamnetin-3-glucoside have also been identified from needles of Scots pine ( $P$. sylvestris). The concentrations of mono- and dicoumaroyl derivatives of isoquercitrin were measured to be $0.17-0.27 \%$ and $0.13-0.22 \%(\mathrm{dw})$, respectively (Turtola et al. 2006; Stolter et al. 2009).

Kaempferol-3-O-rhamnoside, quercetin aglycone, and their $3^{\prime}-O$ - and 7-O-glucosides have been found in 
the bark of Scots pine ( $P$. sylvestris) (Pan and Lundgren 1995). The inner bark proved to contain quercetin, 3-O-methylquercetin, and quercetin glycosides, kaempferol, and some kaempferol derivatives (Rauha et al. 2000).

\section{Flavonols in Norway spruce (Picea abies)}

In addition to kaempferol, quercetin, and isorhamnetin derivatives, several myricetin derivatives have been found in needles of Norway spruce ( $P$. abies) (Slimestad et al. 1999) e.g. laricitrin (3'$O$ methylmyricetin) and syringetin $\left(3^{\prime}, 5^{\prime}-O\right.$-dimethylmyricetin). These flavonols have also been observed to be present in the form of 3-O-glucoside, 3-(6"-acetyl)glucoside and 3-O-rutinoside. Furthermore, kaempferol, quercetin, myricetin, and syringetin glucosides substituted at the 7 position, as well as kaempferol3,4'-diglucoside, myricetin-3,4'-diglucoside, and quercetin- $3^{\prime}$-glucoside, have been isolated and identified in the spruce needles. Hence, in Norway spruce (P. abies) the glycosylation of flavonols occurs mainly at the 3 position as glucose and rutinose complexes are formed. From acylated flavonols, mono- and dicoumaroyl astragalin and dicoumaroyl isorhamnetin-3glucoside have been identified in the needles and quercetin- $3^{\prime}$-glucoside and isorhamnetin 3-O- $\left(6^{\prime}-O\right.$ acetyl)-glucoside in root bark (Pan and Lundgren 1995).

\section{Dihydroflavonols}

Pinobanksin (Fig. 2) is an exception among dihydroflavonols due to the absence of the B-ring substitution (Ondrias et al. 1997; Metacyc 2019). It inhibits peroxidation of low density lipoproteins (LDL) and it has electron donor properties reducing $\alpha$-tocopherol radicals, of which many have vitamin $\mathrm{E}$ activity. Pinobanksin-3-acetate has been reported to be active against $S$. mutans and $S$. sorbinus with the MIC values of $500 \mu \mathrm{M}\left(157 \mathrm{mg} \mathrm{L}^{-1}\right)$ and $250 \mu \mathrm{M}\left(79 \mathrm{mg} \mathrm{L}^{-1}\right)$, respectively (Koo et al. 2002).

The Fig. 2 shows the dihydroflavonols found in needles of Scots pine, which are dihydrokaempferol (aromadendrin), dihydroquercetin (taxifolin), and dihydromyricetin (ampelopsin). Glucosides of all these dihydroflavonols have also been detected in needles of Norway spruce (P. abies) (Slimestad et al. 1999). The dihydroflavonols differ from each other in the sense that aromadendrin has a hydroxyl group at the $4^{\prime}$ position, taxifolin has two hydroxyl groups at the $3^{\prime}$ and $4^{\prime}$ positions, and ampelopsin has three hydroxyl groups at the $3^{\prime}, 4^{\prime}$ and $5^{\prime}$ positions in the flavonol structure, which has the 3-hydroxyflavone backbone. Taxifolin was found to be a powerful antioxidant and to have antiradical activities in several in vitro bioassays when compared with standard antioxidant compounds (Topal et al. 2016).

In Europe, there are two Scots pine ( $P$. sylvestris) chemotypes with respect to the taxifolin- $3^{\prime}-O$-glucoside. One of the pines lacks taxifolin glucoside whereas the other has taxifolin in needles at concentrations of 3-4\% of dw (Laracine-Pittet and Lebreton 1988). Taxifolin-3'-O-glucoside has also been reported to exist in pine (Oleszek et al. 2002; Larsson et al. 1992) but at much lower concentrations (0.004-0.16\% of dw). Taxifolin-3'-O-glucoside with the corresponding aglycone have also been identified from bark of Scots pine ( $P$. sylvestris) (Karonen et al. 2004). Generally, the (+)-chemotype glucosides have not only been identified as taxifolin glucosides, but also as ampelopsin-type (dihydromyricetin, Fig. 2) and flavanone-type eriodictyol glucosides (Larsson et al. 1992).

\section{Antibacterial activity of flavonols}

$\mathrm{Xu}$ and Lee (2001) investigated the relationship between structure and activity in 38 different flavonoids against the multiple drug-resistant, Gram-negative rumen bacterium, Mannheimia succiniciproducens (MBEL55E). They noticed that flavonols are among the most active antibacterial flavonoids and that the active flavonoids have a keto group at the 4 position, hydroxyl groups at the 3, 5 and 7 positions, and, at least, one hydroxyl group in the B-ring. Furthermore, the more hydrophilic flavonols appeared to be better inhibitors than the less hydrophilic ones.

Taxifolin-7-O-rhamnopyranoside and aromadendrin-7-O-rhamnopyranoside isolated from Hypericum japonicum have been studied and been determined as effective against isolates of $S$. aureus (MRSA). Ten clinical isolates justified the MIC values at 32-64 $\mathrm{mg} \mathrm{L}^{-1}$ for taxifolin-7-orhamnopyranoside 
and at $64-128 \mathrm{mg} \mathrm{L}^{-1}$ for aromadendrin-7-Orhamnopyranoside. The corresponding minimum bactericidal concentration (MBC) values were 64-128 $\mathrm{mg} \mathrm{L}^{-1}$ and $128-512 \mathrm{mg} \mathrm{L}^{-1}$, respectively. The MBC values were defined as the lowest concentration of the tested compound that results in the death of more than $99.9 \%$ of the bacterial population. The possible synergy of taxifolin-7-O-rhamnopyranoside with four conventional antibiotics ampicillin, levofloxacin, ceftazidime, and azithromycin has also been investigated. An enhanced efficacy has been found, but only with ceftazidime and levofloxacin against clinical isolates of methicillin-resistant MRSA (An et al. 2011).

Quercetin is the aglycone form of a number of other flavonoid glycosides, such as rutin and quercitrin. Of the flavonoids present in Scots pine ( $P$. sylvestris) and Norway spruce, quercetin (Rauha et al. 2000; Xu and Lee 2001; Ibewuike et al. 1997; Puupponen-Pimiä et al. 2001), kaempferol (Rauha et al. 2000; Tsuchiya et al. 1996; Xu and Lee 2001), and myricetin (Xu and Lee 2001; Puupponen-Pimiä et al. 2001) aglycones, which are produced from the parent compound taxifolin, were determined to have antibacterial activity. Generally, the glycosides of the flavonols were observed to be inactive (Xu and Lee 2001; Puupponen-Pimiä et al. 2001; Silva et al. 2010), although acetylated glycosides of flavonols are observed to be antibacterial ( $\mathrm{Si}$ et al. 2016). However, synergistic antibacterial activities between flavonols and their glycosides have been observed. The inhibitory action of quercetin was enhanced by threefold when it was combined with guercitrin as a (1:1) mixture against Salmonella enteritidis and B. cereus (Arima et al. 2002). In addition, an increased inhibition against $B$. cereus was noticed with the combination of quercetin3-O-rutinoside (rutin) and quercetin as well as that with quercetin-3-O-rutinoside and quercetin-3-Orhamnoside (quercitrin glycoside). Rutin and quercetin-3-O-galactoside (hyperoside) glycosides alone have also indicated antibacterial activity against the Gram-positive bacteria $S$. epidermidis and S. aureus (van der Watt and Pretorius 2001).

Quercetin has exhibited antibacterial activity against $M$. luteus, B. subtilis, S. aureus, S. epidermidis, E. coli, $P$. aeruginosa (Rauha et al. 2000), and $H$. pylori (Martini et al. 2009; Bonacorsi et al. 2012). MIC values of $604 \mathrm{mg} \mathrm{L}^{-1}$ against $S$. aureus (Ibewuike et al. 1997) and MBC of $<200 \mathrm{mg} \mathrm{L}^{-1}$ against
H. pylori (Martini et al. 2009) have been reported. 3-O-Methylquercetin isolated from flowers of the Rwandese medicinal plant (Helichrysum odoratissimum) has been shown to have strong antibacterial activity against a wide range of bacteria (van Puyvelde et al. 1989); the MIC values from 6.25 to $100 \mathrm{mg} \mathrm{L}^{-1}$ were observed against several Gram-negative $(E$. cloaceae, E. coli, K. pneumoniae, P. vulgaris, $P$. aeruginosa, Pseudomonas solanacearum, S. typhimurium, Serratia marcescens, Shigella dynasteriae), and Gram-positive (B. subtilis, Mycobacterium smegmatis, S. aureus, Streptococcus pyogenes) bacteria (Table 1).

Kaempferol has shown to have a slight activity against $B$. subtilis, and a clear activity against $S$. aureus, but no activity against E. coli, M. luteus, or $S$. epidermidis (Rauha et al. 2000). Liu et al. (1999) have studied several acylated kaempferol-3-O-glucosides against Gram-positive bacteria. They noticed that the most effective compounds were those having one or two $c i s$-p-coumaroyl groups. Acylation was noticed to improve the activity of kaempferol against MRSA (Otsuka et al. 2008). The MIC values of kaempferol-3$O$ - $\left(2^{\prime \prime}, 4^{\prime \prime}\right.$-di- $E$ - $p$-coumaroyl)-rhamnoside and kaempferol 3-O-(2"-Z-p-coumaroyl, $4^{\prime \prime}-E$-p-coumaroyl)rhamnoside isolated from Laurus nobilis were $0.5-2 \mathrm{mg} \mathrm{L}^{-1}$. The anti-MRSA activity of these compounds was much higher than that of several chemotherapics (oxacillin, ciprofloxacin, norfloxacin, erythromycin, and tetracycline) and almost as high as that of vancomycin. The MIC values of these compounds against Enterococcus faecium and $E$. faecalis were $8 \mathrm{mg} \mathrm{L}^{-1}$ and $4 \mathrm{mg} \mathrm{L}^{-1}$, respectively.

$\mathrm{Xu}$ and Lee (2001) have shown that flavonoids have activity against antibiotic-resistant bacteria and observed that myricetin was the most effective against MRSA, vancomycin-resistant enterococci (VRE) and Burkholderia cepacia with MIC values of $128 \mathrm{mg} \mathrm{L}^{-1}$, $128 \mathrm{mg} \mathrm{L}^{-1}$, and $32 \mathrm{mg} \mathrm{L}^{-1}$, respectively. Furthermore, myricetin also inhibited the growth of $K$. pneumoniae, whereas quercetin (MIC $256 \mathrm{mg} \mathrm{L}^{-1}$ ) and kaempferol (MIC $>512 \mathrm{mg} \mathrm{L}^{-1}$ ) inhibited only the growth of MRSA. It has been determined that the myricetin activity against $B$. cepacia was related to its inhibition of protein synthesis. It has also been observed that myricetin is the most active flavonol aglycone against different bacteria (Puupponen-Pimiä et al. 2001). In particular, the strongest inhibition was noticed against $E$. coli. 


\section{Flavan-3-ols and anthocyanidins}

The flavan-3-ols have two asymmetric carbon atoms (chiral carbons) at the positions 2 and 3 . The most important flavan-3-ols occurring in nature are $(+)$ catechin $\left(2 R, 3 S-3,5,7,3^{\prime}, 4^{\prime}\right.$-pentahydroxyflavan $)$ and $(+)$-gallocatechin $\left(2 R, 3 S,-3,5,7,3^{\prime}, 4^{\prime}, 5^{\prime}\right.$-hexahydroxyflavan). (+)-Catechin has been found in needles (Rosemann et al. 1991), twigs (Stolter et al. 2009), bark (Karonen et al. 2004; Lavola et al. 2003) and root bark (Pan and Lundgren 1995) of Scots pine ( $P$. sylvestris) and in needles (Jyske et al. 2014), and in inner bark (Gehlert et al. 1990) of Norway spruce. Catechin-3-glucoside has also been identified in bark of Scots pine (P. sylvestris) (Pietarinen et al. 2006; Karonen et al. 2004; Lavola et al. 2003) and 3'-Omethylcatechin has been detected in bark (Karonen et al. 2004; Lavola et al. 2003), root bark (Pan and Lundgren 1995) and needles (Slimestad et al. 1999) of Norway spruce ( $P$. abies). A strong increase in the catechin concentration in inner bark of Norway spruce ( $P$. abies) has been observed, due to its response to wounding (Lieutier et al. 2003), which suggests that catechin has strong antimicrobial activity. Slight activity against $H$. pylori has been observed for (+)catechin isolated from Byronima crassa (Bonacorsi et al. 2012). The most common catechin isomer (+)catechin is inactive against MRSA, but generally acyl chains at the 3 position have been observed to enhance the anti-staphylococcal activity of the molecule (Stapleton et al. 2004).

$(+)$-Epicatechin has been found in the bark of Scots pine (P. sylvestris) (Karonen et al. 2004; Lavola et al. 2003) and epicatechin as well as gallocatechin in needles of Norway spruce (P. abies) (Slimestad et al. 1999). Catechin and epicatechin have been shown to exhibit activity against $B$. subtilis and E. coli (Min et al. 2009; Idowu et al. 2010), whereas (-)-epigallocatechin gallate and (-)-epicatechin gallate have shown activity against $S$. aureus (Akiyama et al. 2001). It has also been observed that (-)-epicatechin gallate sensitizes MRSA to $\beta$-lactam antibiotics by affecting the architecture and composition of the cell wall of the MRSA bacterium (Stapleton et al. 2007).

The anthocyanin glycosides (anthocyanins) pelargonidin-, cyanidin-, delphinidin-, and peonidin3- glucosides have been observed in spruce needles (Slimestad et al. 1999). Cyanidin-3-glucoside isolated from berry extract and extracted from pomegranate fruit (Punica granatum) has exhibited activity against E. coli (Puupponen-Pimiä et al. 2001) and against species of corynebacteria, staphylococci, streptococci, B. subtilis, Shigella, Salmonella, Vibrio cholera, and E. coli (Naz et al. 2007). In addition, pelargonidin-3galactoside extracted from pomegranate fruit has exhibited similar activity (Naz et al. 2007).

\section{Proanthocyanidins}

Proanthocyanidins, also called condensed tannins, are oligomers and polymers with the flavan-3-ol units. They are fairly soluble in water and are able to precipitate proteins. Proanthocyanidins can be classified into several subclasses based on the hydroxylation and stereochemistry of the flavan-3-ol head and extension units. The position of intermolecular linkages, the degree of polymerisation, branching extent, glycosylation, and modifications such as esterification of the 3-hydroxyl group have a specific role in the classification (Kraus et al. 2003; Dixon et al. 2005).

Flavan-3-ol units can be linked together by A- and B-types of linkages, in which B-type bonds are more frequent and typically $\mathrm{C} 4 \rightarrow \mathrm{C} 8$, although $\mathrm{C} 4 \rightarrow \mathrm{C} 6$ linkages also exist (Stevanovic et al. 2009; Smolander et al. 2012). The two main proantocyanides are procyanidins having a dihydroxyl B-ring $\left(3,5,7,3^{\prime}, 4^{\prime}\right.$ pentahydroxylation) and prodelphinidins with a trihydroxyl B-ring $\left(3,5,7,3^{\prime}, 4^{\prime}, 5^{\prime}\right.$-hexahydroxylation $)$ (Fig. 4). Occasionally, an additional ether bond from $\mathrm{O} 7 \rightarrow \mathrm{C} 2$ or $\mathrm{O} 5 \rightarrow \mathrm{C} 2$ may exist, leading to doublebonded A-type proanthocyanidins (Stevanovic et al. 2009; Hellström and Mattila 2008). The structures of dimeric procyanidin and prodelphin with A-type (elongated structure) and B type (loop structure) linkages are presented in Fig. 4. The (epi)catechins are the most commonly found constitutive units of the procyanidins in temperate zone conifer heartwoods and barks (Stevanovic et al. 2009), whereas prodelphinidins consists of (epi)gallocathechins. The size of the proanthocyanidins varies from dimers to very large polymers with average degrees of polymerization ranging from 3 to 8 (Holmbom 2011).

Callus culture of Scots pine ( $P$. sylvestris) has been found to be rich in proanthocyanidins. Concentrations of bound and free proanthocyanidins are $8.8 \%$ and $3.0 \%$ from dw, respectively (Shein et al. 2003). Proanthocyanidins can be extracted from bark samples 
Fig. 4 Structures of dimeric procyanidin and prodelphinidin with $\mathrm{A}$ - and B-type linkages. Modified from the paper of Hellström and Mattila (2008)

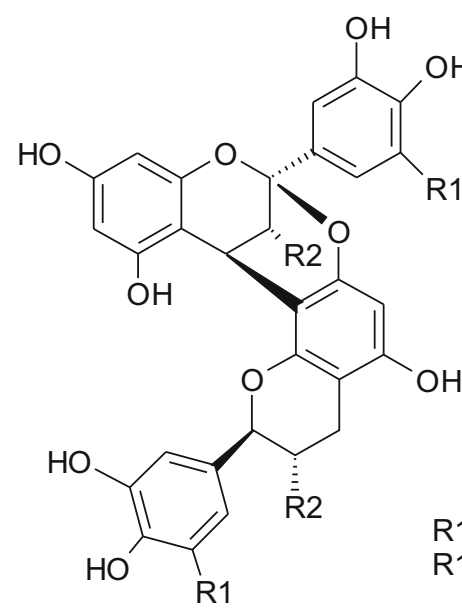

$\mathrm{R} 1=\mathrm{H}$ Procyanidin $\mathrm{R} 1=\mathrm{OH}$ Prodelphinidin

$\mathrm{R} 2=\mathrm{OH}$ non-esterified R2=galloyl esterified

A-type<smiles>[R1]c1cc([C@H]2Oc3cc(O)cc(O)c3[C@H](c3c(O)cc(O)c4c3O[C@H](c3cc([R1])c(O)c(O)c3)[C@H]([R2])C4)C2[R2])cc(O)c1O</smiles>

$\mathrm{OH}$

Tannins have been used in the tanning of leather for

with hot water (Matthews et al. 1997). It was noticed that bark of Scots pine ( $P$. sylvestris) contains procyanidin-type proanthocyanidins, but prodelphinidins were not found. It was also reported that pine bark comprehended $3.1 \%$ of dw non-water-soluble proanthocyanidins and $1.0 \%$ of water-soluble procyanidins. The latter compounds were found mainly in the inner bark. The epicatechin/catechin-ratio of 79/23 (w/w) and a degree of polymerisation of 5.3 were detected for water-soluble procyanidins. Bark of Norway spruce ( $P$. abies) contained both types of proanthocyanidins and more water-soluble proanthocyanidins than bark in Scots pine. The amounts of $0.08 \%$ and $3.6 \%$ of water-soluble prodelphinidin and procyanidin, respectively, were detected. With an epicatechin/catechin-ratio of $80 / 20(\mathrm{w} / \mathrm{w})$ the degree of polymerisation of 4.6 was detected. Proanthocyanidins have also been identified in needles of Scots pine $(P$. sylvestris) and Norway spruce ( $P$. abies). The reported proanthocyanidins contents were $2.2 \%$ and $6.5 \%$ from dw, respectively (Kanerva et al. 2008). Both prodelphinidins and procyanidin types from monomers and dimers (molar masses of 290-610 $\mathrm{g} \mathrm{mol}^{-1}$ ) to higher polymers were detected. In contrast to the bark samples detected by Matthews et al. (1997), needles of Scots pine (P. sylvestris) were reported to contain more prodelphinidin than procyanidin units (Kanerva et al. 2006), which showed the heterogeneity of the wood materials and different recoveries in the extracts. their well-known ability to make complexes with proteins. They are considered to be antibacterial compounds as they can also denature proteins in bacterial cell membranes. The activity of proanthocyanidins varies from compound to compound. Thus, procyanidin A2 (epicatechin dimer) has been reported to exhibit weak activity against B. subtilis (Plant Metabolic Network 2012). However, prodelphinidin isolated from Sericea lespedeza has been observed to show a moderate activity against $K$. pneumoniae and $E$. coli and a high activity against $S$. aureus (Min et al. 2009).

\section{Benzoic acid and cinnamic acid derivatives}

Compounds with C6-C1 and C6-C3 skeletons are commonly classified as benzoic acids derivatives (hydroxybenzoic acids) and cinnamic acid derivatives (hydroxycinnamic acids). The compounds are found in both Scots pine (P. sylvestris) and Norway spruce (P. abies) (Fig. 5).

\section{Biosynthesis of hydroxybenzoic acids}

Several possible biosynthesis routes are proposed for production of hydroxybenzoic (el Basyouni et al. 1964) and hydroxycinnamic acids (Reddy et al. 2005; Koutaniemi 2007; Chen et al. 2011). The 

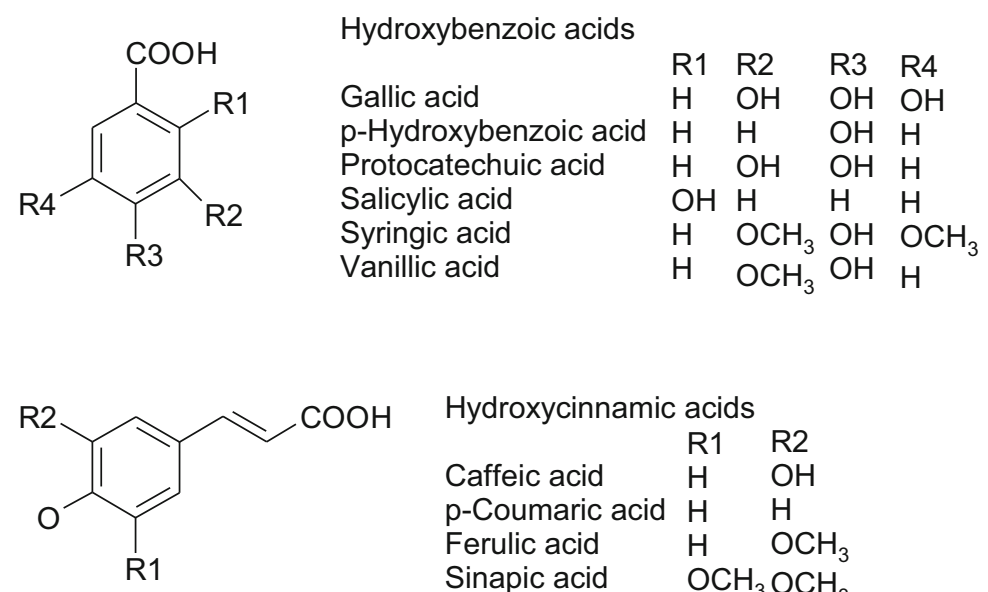

\begin{tabular}{lll}
\multicolumn{3}{l}{ Hydroxycinnamic acids } \\
& $\mathrm{R} 1$ & $\mathrm{R} 2$ \\
Caffeic acid & $\mathrm{H}$ & $\mathrm{OH}$ \\
p-Coumaric acid & $\mathrm{H}$ & $\mathrm{H}$ \\
Ferulic acid & $\mathrm{H}$ & $\mathrm{OCH}_{3}$ \\
Sinapic acid & $\mathrm{OCH}_{3} \mathrm{OCH}_{3}$
\end{tabular}<smiles>CCOc1ccc(C(C)=O)cc1</smiles>

Fig. 5 Structures of simple phenols found in pine and spruce

hydroxybenzoic acids include salicylic acid, benzoic acid, p-hydroxybenzoic acid, protocatechuic acid, and vanillic acid (Fig. 6). Especially salicylic acid (2hydroxybenzoic acid) can be produced by two different biosynthesis routes (Wildermuth et al. 2001; Shah 2003). Benzoic acid-2- hydroxylase (BA2H) forms salicylic acid from phenylalanine through cinnamic and benzoic acids. The other route goes via a shikimic acid pathway through chorismic and isochorismic acids aided by isochorismate synthase (ICS) and isochorismate pyruvate lyase (IPL).

Three alternative biosynthesis pathways have been proposed for the formation of gallic acid (3,4,5trihydroxybenzoic acid) (Ishikura et al. 1984; Ossipov et al. 2003), namely oxidation of 3,4,5-trihydroxycinnamic acid, hydroxylation of 3,4-dihydroxybenzoic acid (protocatechuic acid), and direct dehydrogenation of 3-dehydroshikimic acid (Fig. 7). Most probably, gallic acid is derived from shikimic acid (Fig. 7) by dehydrogenation of 3-dehydroshikimic acid (Vogt 2010). This has been researched to be the most probable pathway for gallic acid also in birch leaves (Ossipov et al. 2003).

p-Hydroxybenzoic, salicylic, protocatechuic, vanillic, gallic, and syringic acids have been detected in mature seeds (Cvikrová et al. 2008) and in the roots of Norway spruce ( $P$. abies) (Malá et al. 2011; Münzenberger et al. 1990). Glycosides of $p$-hydroxybenzoic acid and vanillic acid derivatives have been detected in bark of Scots pine (P. sylvestris) (Karonen et al. 2004; Pan and Lundgren 1996). Especially, a callus culture of Scots pine ( $P$. sylvestris) has been noticed to contain a very high concentration of $p$-hydroxybenzoic acid (31.4\% of dw) (Shein et al. 2003).

\section{Biosynthesis of hydroxycinnamic acids}

Hydroxycinnamic acids are important for plant growth and development. Therefore, they are among the most widely distributed phenylpropanoids in plant tissues (Rice-Evans et al. 1996). The hydroxycinnamic acids such as $p$-coumaric, caffeic, ferulic, and sinapic acids are precursors of monolignols (coniferyl alcohol, sinapyl alcohol, and paracoumaryl alcohol) and are directly linked to lignin biosynthesis (Fig. 7). Hydroxycinnamic acid and its glycosides, as well as esters and amides are present in various parts of forest trees and particularly, in the cork part of the bark (Stevanovic et al. 2009). Free and bound forms of phenolic acids, and their esters and ethers have been detected in the cambium and xylem of Scots pine (P. sylvestris) (Antonova et al. 2011). In the cambium zone, the most abundant phenolic acid was $p$-coumaric acid (Fig. 7) as ether and ester forms. Sinapic acid (Fig. 8) has been shown to dominate in the secondary thickening zone of the xylem, both in the free form and as ester and ether forms. It is noteworthy that caffeic and ferulic acids (Fig. 8) have been found to be the next most abundant phenolic acids.

In Norway spruce, ferulic and sinapic acids are most probably synthesized from coniferylaldehyde 


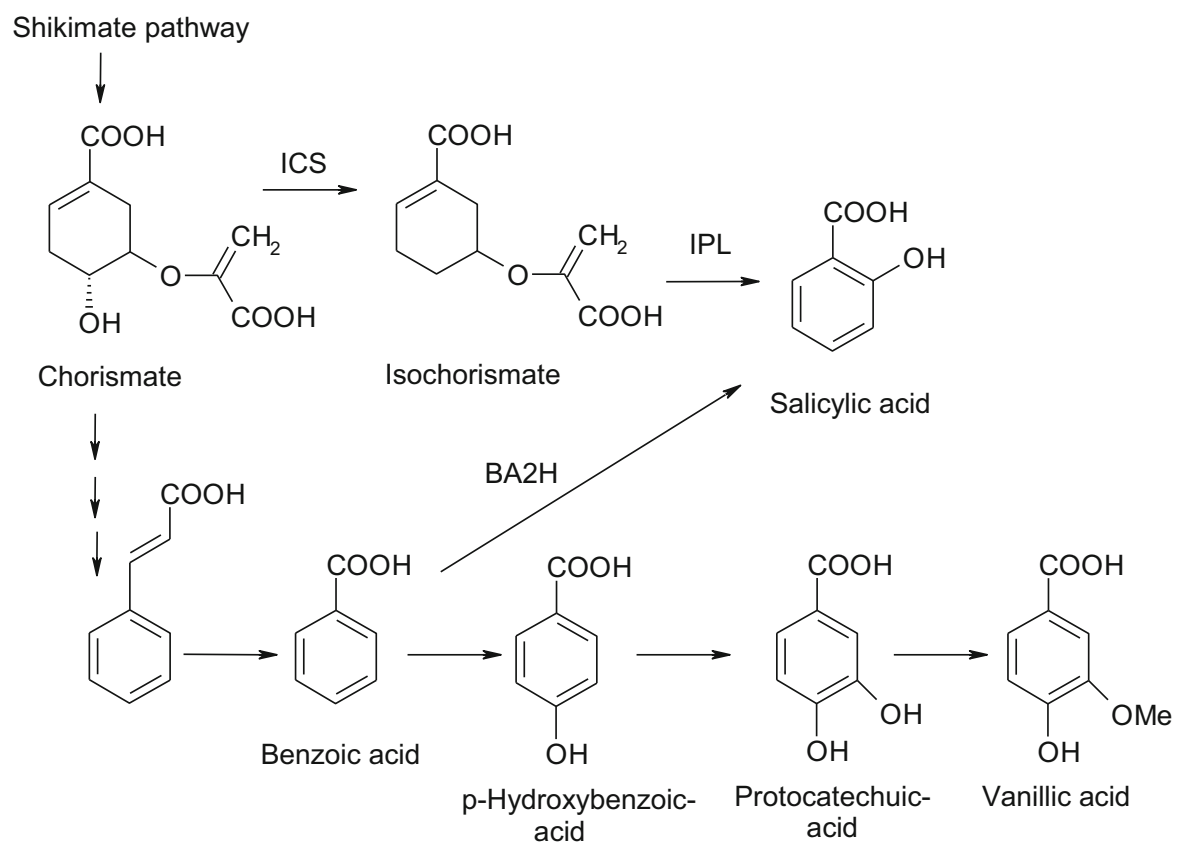

Fig. 6 Proposed biosynthesis pathways for salicylic and vanillic acids in plants. $B A 2 H$ benzoic acid-2 hydroxylase; ICS isochorismate synthase; IPL isochorismate pyruvate lyase.
Redrawn from papers of El Basyouni et al. (1964), Wildermuth et al. (2001), and Shah (2003)

methylated to the same position in catalysis by 5hydroxyconiferaldehyde $O$-methyltransferase (EC 2.1.1.68).

\section{Antibacterial activity of small phenolic compounds}

The antibacterial properties of wood are clarified by using extractives and lignin. The phenolic compounds from heartwood of Scots pine ( $P$. sylvestris) have the strongest antibacterial effect based on the extract analyses. On the contrary, cellulose and hemicellulose surfaces act as polysaccharide nutrition for bacteria (Vainio-Kaila et al. 2017).

Gallic acid has shown antibacterial activity against several bacterial species. When isolated from pomegranate fruit ( $P$. granatum), it has exhibited activity against species of corynebacteria, staphylococci, streptococci, B. subtilis, Shigella, Salmonella, V. cholera, and E. coli (Naz et al. 2007). Gallic acid was more active against Gram-positive than Gramnegative bacteria. On the other hand, gallic acid was found to be active against strains belonging to the Gram-negative genus Shigella that consists of a group 
<smiles>CC(=O)C1=CC(=O)[C@H](O)[C@H](O)C1</smiles><smiles>NC(Cc1ccccc1)C(=O)O</smiles>

Phenylalanine<smiles>O=C(O)C=Cc1ccccc1</smiles>

Cinnamic acid<smiles>O=C(O)c1ccc(O)c(O)c1</smiles>

Protocatechuic acid<smiles>C1CCCCC1</smiles>

Gallic acid<smiles>C1CCCCC1</smiles><smiles>O=c1oc2c(O)c(O)cc3c(=O)oc4c(O)c(O)cc1c4c23</smiles>

Ellagic acid<smiles>O=C(O)/C=C/c1ccc(O)cc1</smiles>

p-Coumaric acid<smiles>O=C(O)/C=C/c1ccc(O)c(O)c1</smiles><smiles>O=C(O)C=Cc1cc(O)c(O)c(O)c1</smiles>

Caffeic acid

3,4,5-Trihydroxycinnamic acid

Fig. 7 Proposed biosynthetic pathways for the formation of gallic acid. Redrawn from the paper of Ishikura et al. (1984)

of facultative aerobic, non-spore-forming, non-motile, and rod-shaped bacteria which are genetically closely related to E. coli. Gallic acid has also been isolated as one of the components from latex of Himathanthus sucuuba (Spruce) Woodson (Apocynaceae). It has strong antimicrobial and antibacterial activity which has been tested against S. aureus, Staphylococcus epidermis, Staphylococcus, haemolyticus, E. coli, and P. mirabilis (Silva et al. 2010) with MIC values varying from 31 to $125 \mathrm{mg} \mathrm{L}^{-1}$. The antibacterial activity of gallic acid and its methyl ester showed even stronger activity than that, since the values from 3.5 to $12.5 \mathrm{mg} \mathrm{L}^{-1}$ were determined (Al-Zahrami 2012). At that time, the studies were done with different isolates of $S$. aureus. Gallic acid has also been reported to inhibit the growth of $P$. aeruginosa that is a common
Gram-negative, rod-shaped bacterium and causes disease in plants, animals, and humans (Rauha et al. 2000) and $H$. pylori that is a Gram negative, microaerophilic bacterium usually found in the stomach, and thought to be associated to gastric ulcers (Martini et al. 2009).

Protocatechuic acid and isovanillic acid have been isolated from the aerial parts of Centaurea spruneri for antibacterial activity tests (Ćirić et al. 2011). Their MIC and MBC values against B. cereus, Micrococcus flavus, S. aureus, L. monocytogenes, E. coli, P. aeruginosa, $P$. mirabilis, and $S$. typhimurium were in the range of $100-400 \mathrm{mg} \mathrm{L}^{-1}$. However, much stronger bioactivity was detected, when they examined the activity of protocatechuic acid against food spoilage bacteria $S$. typhimurium, E. coli, $L$. 


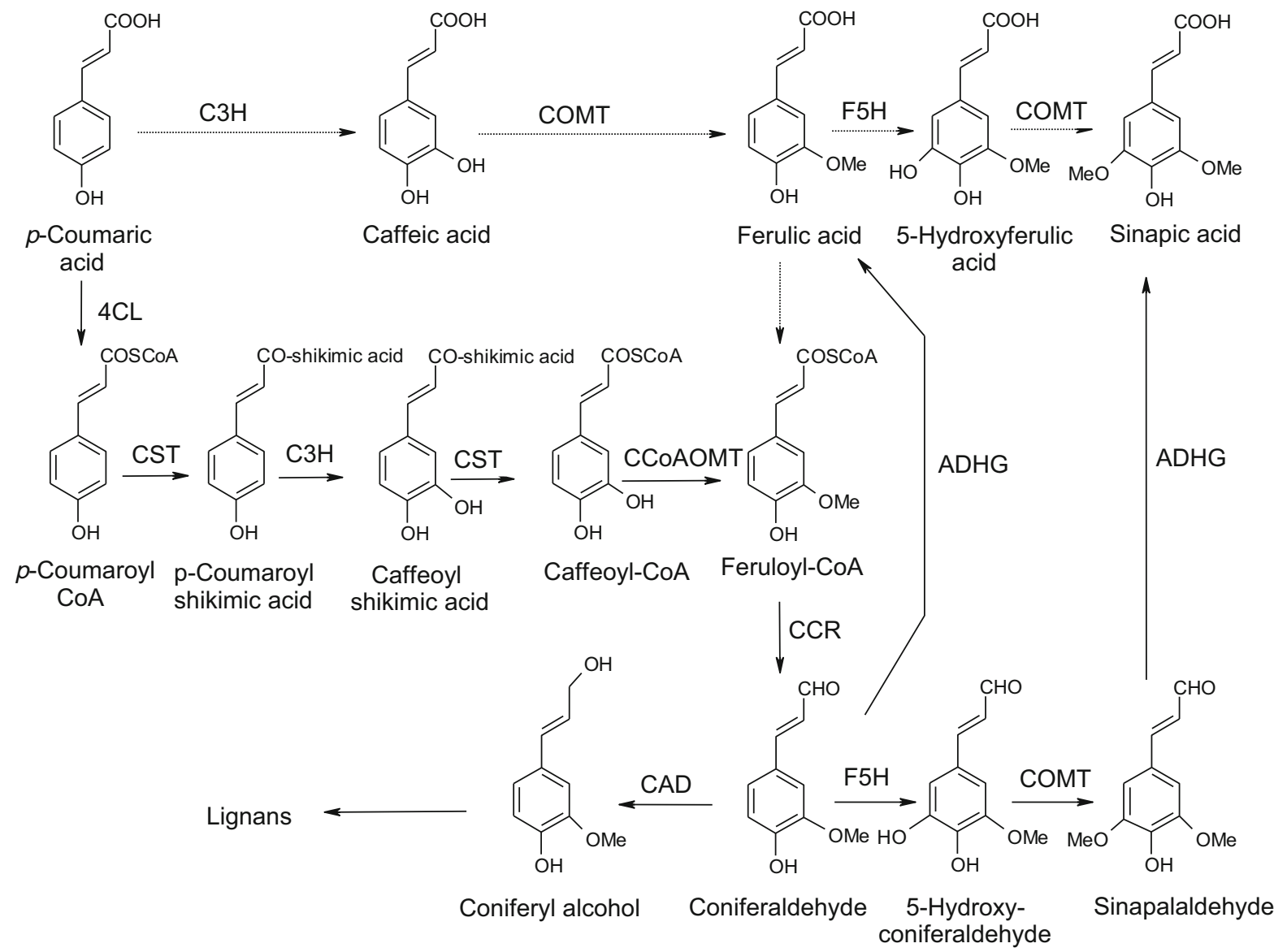

Fig. 8 Proposed coniferyl alcohol and lignan biosynthesis pathways. 4CL 4-Coumaric acid:CoA ligase; $A D H G$ aldehyde dehydrogenase; $C 3 H$ p-coumarate 3-hydroxylase; $C A D$ cinnamyl alcohol dehydrogenase; $C C O A O M T$ caffeoyl CoA $O$ methyltransferase; $C C R$ cinnamoyl $\mathrm{CoA}$ reductase; COMT

monocytogenes, $S$. aureus, and B. cereus (Chao and Yin 2009). Then the MIC ranged from 24 to $44 \mathrm{mg} \mathrm{L}^{-1}$.

Cinnamic, $p$-coumaric, caffeic, ferulic, and chlorogenic acids (Fig. 7) isolated from berry extract have exhibited activity against $E$. coli and $S$. enterica (Puupponen-Pimiä et al. 2001). Cinnamic acid has also shown antibacterial activity against $S$. aureus and E. aerogenes, as well as against the yeast, Candida albicans (Nascimento et al. 2000). The bioactivity may originate from their structure, since they all are carboxylic acids with hydrophilic properties. It has been determined that ferulic acid, which has a hydroxycinnamic acid structure, has bioactivity against B. subtilis, S. epidermis, S. aureus, and caffeic acid/5-hydroxyferulic acid $O$-methyltransferase; $C S T$ hydroxycinnamoyl CoA:shikimic acid hydroxycinnamoyltransferase; $F 5 H$ ferulate 5-hydroxylase. Redrawn from the papers of Reddy et al. (2005), Koutaniemi (2007), and Chen et al. (2011)

Streptococcus pneumoniae (van der Watt and Pretorius 2001). As a component of lignin, ferulic acid is a precursor of many aromatic compounds.

Chemically synthetized chlorogenic, caffeic, and protocatechuic acids have similar inhibition against $S$. mutans than those originated from wood. Their use in medical purposes is meaningful, since $S$. mutans is regarded as the main microbial agent causing dental caries (Almeida et al. 2012). Ferulic acid and vanillic acid (an intermediate in the production of vanillin from ferulic acid) (Figs. 7 and 8) have been isolated from the root bark of Onosma hispidum (Boraginaceae). They have been observed to be inactive against Gram-negative bacteria and to exhibit antibacterial activity against E. faecalis, S. pneumoniae, $S$. 
pyogenes, and Corynebacterium diphtheria. Ferulic acid also has bioactivity against $S$. aureus, $S$. epidermis, and Staphylococcus saprophyticus (Naz et al. 2007).

Commercial $p$-coumaric acid (Fig. 5), which is a hydroxyl derivative of cinnamic acid (Fig. 7) has been noticed to have comparable high activity against the Gram-positive bacteria $S$. aureus, B. subtilis, and $S$. pneumoniae, with an MIC of $20 \mathrm{mg} \mathrm{L}^{-1}$ (Lou et al. 2012). Shigella dysenteriae and S. typhimurium were the most susceptible Gram-negative bacteria with the MIC vales of $10 \mathrm{mg} \mathrm{L}^{-1}$ and $20 \mathrm{mg} \mathrm{L}^{-1}$, respectively. In this case, E. coli was the most resistant bacterium with the MIC of $80 \mathrm{mg} \mathrm{L}^{-1}$ (Table 1).

However, caffeic acid, which belongs to the group of hydroxycinnamic acids, exhibited high antioxidant properties, which increased when the concentration was increased. It was also demonstrated that caffeic acid is a stronger reducing agent in the oxidation processes than cinnamic acid (Masek et al. 2016). It was observed that $p$-coumaric acid has dual mechanisms of bactericidal activity. The mechanisms disrupt bacterial cell membranes, bind to the DNA and inhibit related cellular functions, and ultimately lead to cell death.

Caffeic and $p$-hydroxybenzoic acids were tested for the development of antibacterial cellulose packing material and paper hand sheets (Elegir et al. 2008). A strong bactericidal effect was noticed against $S$. aureus with a concentration of $552 \mathrm{mg} \mathrm{L}^{-1}$, whereas a higher concentration was needed to kill E. coli. Phenolic acids and flavonols as food preservatives were also investigated (Rodríguez Vaquero et al. 2011). The synergistic antibacterial effect of phenolic acid mixtures against L. monocytogenes was observed with combinations of gallic acid-caffeic acids, gallic acid—protocatechuic acids, and rutin- quercetin.

The antimicrobial effects of the wood-associated polyphenolic compounds pinosylvin, pinosylvin monomethyl ether, astringin, piceatannol, isorhapontin, and isorhapontigenin (Fig. 1) have been assessed against both Gram-negative (Salmonella) and Grampositive bacteria (L. monocytogenes, S. epidermidis, $S$. aureus) and yeasts (Candida tropicalis, Saccharomyces cerevisiae) (Plumed-Ferrer et al. 2013). In general, the antimicrobial effects of pinosylvin were even more prominent than those of a related stilbene and resveratrol, which are well known for their bioactivities. It has been stated that pinosylvin
(Fig. 1) could have potential as a natural disinfectant or biocide in some targeted applications. (PlumedFerrer et al. 2013).

Picein (Fig. 5), a glucoside of piceol (4-hydroxy acetophenone) has been found in different parts of Norway spruce. Non-mycorrhizal short roots of Norway spruce ( $P$. abies) have been found to contain picein $0.09-0.2 \%$ of dry weight (Flores-Sanchez and Verpoorte 2009). In spruce needles picein and piceol concentrations have been $1.8-2.2 \%$ and $0.4-1.1 \%$ of dry weight (Turtola et al. 2006; Stolter et al. 2009). The antimicrobial potential of the isolated picein has been examined and it has been found to exhibit activity against both Gram-positive and Gram-negative bacteria ( $S$. aureus, S. epidermidis, S. typhimurium, E. coli, B. cereus, K. pneumoniae, E. faecalis, and $P$. aeruginosa) with MIC values ranging from 16 to $64 \mathrm{mg} \mathrm{L}^{-1}$ (Table 1) (Sarıkahya et al. 2011).

\section{Lignans}

Softwood lignans are dimers of coniferyl alcohols linked by $\beta$ - $\beta^{\prime}$-bonds. They are closely related to the biosynthesis of lignins. In the first stage of the lignan biosynthesis (Fig. 9), two coniferyl alcohols are stereo selectively linked by the $\beta$ - $\beta^{\prime}$-bond to produce $(+)$ pinoresinol (Kawai et al. 1999; Kwon et al. 2001; Umezawa 2003). This reaction is started by a laccase or laccase-like enzyme to produce free radicals, which are then oriented by the protein in such a way that they can be coupled only by the $\beta$ - $\beta^{\prime}$-link (Hovelstad et al. 2006).

The primary lignin, pinoresinol, undergoes a variety of conversions, such as ring cleavage, ring formation, and substitution reactions. First, it is enantiomer specifically transformed into lariciresinol and secoisolariciresinol (Fig. 9), which are further converted by dehydrogenation into matairesinol (Stevanovic et al. 2009). Hydroxylation of matairesinols leads to the formation of nortrachelogeninand hydroxymatairesinol (Fig. 9), which can be transformed to $\alpha$ conidendrin (Fujita et al. 1999). The biosynthetic pathway for many other lignans still remains unknown (Umezawa 2003).

The knots of Norway spruce ( $P$. abies) have been observed to be rich in lignans (6-24\% of dw), whereas only trace amounts have been detected in the sapwood (Willför et al. 2003c; Hovelstad et al. 2006). 


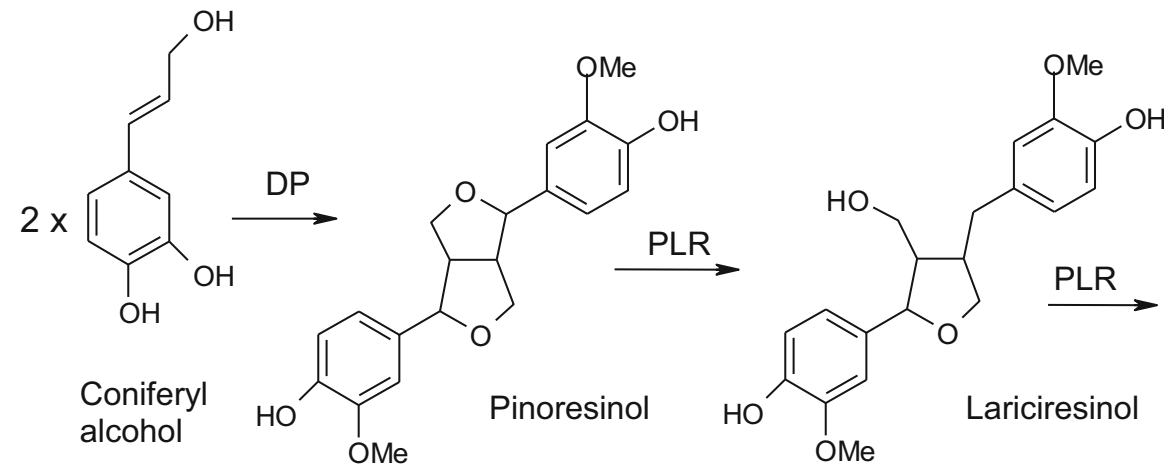<smiles>COc1cc(CC(CO)C(CO)Cc2ccc(O)c(OC)c2)ccc1O</smiles><smiles>COc1cc(CC2COC(=O)C2C(O)c2ccc(O)c(OC)c2)ccc1O</smiles>
Conidendrin Hydroxymatairesinol<smiles>COc1cc(C[C@@H]2COC(=O)[C@]2(O)Cc2ccc(O)c(OC)c2)ccc1O</smiles>

Nortrachelogenin
Secoisolariciresinol<smiles>COc1cc(CC2COC(=O)C2Cc2ccc(O)c(OC)c2)ccc1O</smiles>

Matairesinol

Fig. 9 Common lignan biosynthetic pathway. DP dirigent protein; $P L R$ pinoresinol/lariciresinol reductase; SIRD secoisolariciresinol dehydrogenase. Redrawn from the papers of Kawai et al. (1999), Kwon et al. (2001), and Umezawa(2003)

Hydroxymatairesinol has been reported to be the dominant lignan (65-85\% of the lignans) (Willför et al. 2003c; Hovelstad et al. 2006; Piispanen et al. 2008). Other lignans detected in knotwood of Norway spruce ( $P$. abies) are secoisolariciresinol, $\alpha$-conidendrin, $\alpha$-conidendric acid, isohydroxymatairesinol, lariciresinol, lignan A, matairesinol, nortrachelogenin (wikstromol), todolactol A, and isoliovil (Piispanen et al. 2008). Nortrachelogenin has been found to be the most abundant lignan in Scots pine, but small amounts of lariciresinol, matairesinol, secoisolariciresinol, isoliovil, and liovil have also been determined (Willför et al. 2003c; Pietarinen et al. 2006). A nortrachelogenin content of $31 \%$ in hydrophilic extract of knot wood has been observed (Pietarinen et al. 2006). Lignan glucosides, xylosides, and rhamnosides have been detected in bark of Scots pine ( $P$. sylvestris) (Karonen et al. 2004). Due to the many new lignan chemicals obtained from the wood, their true structures may be incorrect until new characterization and repeated identification is done. Earlier, it was noticed for liovil and olivil (Willför et al. 2005).

Although lignans have various clinically important biological activities against bacteria (Suzuki and Umezawa 2007), they have mostly been reported to be inactive. Apart from nortrachhelogenin and lariciresinol, lignans isolated form Scots pine $(P$. sylvestris) and Norway spruce ( $P$. abies) have been observed to be inactive against several bacteria (Karppanen et al. 2008). However, (+)-lariciresinol $4^{\prime}$-O-glucopyranoside has been noticed to exhibit strong activity against $S$. aureus and $S$. epidermidis with the MIC values of $50 \mathrm{mg} \mathrm{L}^{-1}$ and $25 \mathrm{mg} \mathrm{L}^{-1}$, respectively (Wan et al. 2012). 


\section{Artificially cultivated production of bioactive compounds}

The advantage in sample pre-treatment with enzyme degradation and chemical processing is to allow decomposition of the wood material. Then, naturally the process prevents the real characterization of the wood material and results in a mixture of short-chain organic acids (Sirén et al. 2015). Generally, bioactive compounds have recovered from sources by solidliquid extraction using organic solvents in heat-reflux systems (Martins et al. 2011). Solvent extraction with acetone or hydrophilic solvents are used to isolate lignans which are present in low concentrations in wood. Especially, softwood knots have been researched to contain large amounts of free aglycone lignans (Willför et al. 2003a, b, c, Willför et al. 2004). The lignan nortrachelogenin in knots of Scots pine $(P$. sylvestris) (Eklund et al. 2002) and two diastereomers of the new lariciresinol-type butyrolactone lignan, isohydroxymatairesinol, in knots of Norway spruce (P. abies) were identified long ago (Eklund et al. 2004). Furthermore, other techniques have also been proposed, such as supercritical fluid extraction (SFE) with $\mathrm{CO}_{2}$, hot water extraction (HWE), high pressure processes, and microwave, ultrawave assisted extraction techniques, and accelerated solvent extraction (Martins et al. 2011; Leppänen et al. 2011; Pranovich et al. 2015).

A great deal of attention has been given to biotechnological products, especially when they are produced by cell cultivation technology. When optimizing bioprocesses, the lack of accurate real-time data and the different effects of physical, chemical, and biological hydrolysis may represent a significant bottleneck phenomenon. Interest in the development of bioprocesses for the production or extraction of bioactive compounds from natural sources has increased.

Technologies of cultivation of wood materials has been developed due to production of new enzymes that release phenolic acids to scale-up the processes. One of the techniques is solid state fermentation (SSF) that is used to increase concentrations of compounds having antioxidant activity by bioconversion of phenolic compounds and mobilization of the conjugate forms of phenolic precursors (Laavola et al. 2015; Chao and Yin 2009; Soccol et al. 2017). SSF consists of microbial growth and product formation on solid particles in the absence, or near absence of water, since the substrate itself contains sufficiently of moisture to allow the microorganism growth and metabolism (Jyske et al. 2014; Martins et al. 2011). Especially, ferulic acid and vanillin could be produced by lignolytic enzymes. The action of enzymes such as $\alpha$-amylase, laccase, and $\beta$-glucosidase, and tannin acyl hydrolase have shown mobilization of bioactive phenolic compounds due to SSF processes (Chao and Yin 2009; Robledo et al. 2008). There are specific extracellular enzymes participating in lignin degradation that are lignin peroxidase, manganese peroxidase, and laccase (Philippoussis et al. 2009). Obviously, low molecular weight compounds are originated from microbial metabolism or from plant biomass and act as diffusible oxidizing agents.

The extraction conditions can be modified concerning the recovery of specific polyphenols from the wood samples. Various sample preparation techniques have different demands in optimization (Fang et al. 2013). Specific polyphenols can be isolated from knots of Scots pine (P. sylvestris) by means of an accelerated solvent extractor (ASE). In addition, hot water and $85 \%$ aqueous ethanol were good solvents for the production of the substances. Polyphenols can be extracted from plants by different solvent systems.

The yield depends on the extraction method, the polarity of the solvent, and the extraction temperature and time, just to mention a few (Xu and Chang 2007). Aqueous ethanol mixtures are more efficient to this purpose than the pure water and ethanol (Yilmaz and Toledo 2006; Spigno et al. 2007). The yields are high, but the selectivity for phenolic compounds is low.

An industrial knotwood sample from a pulp mill was sequentially extracted with cyclohexane and ethanol/water (95:5) in a large-scale Soxhlet equipment. The total amount could be recovered by the initial extraction with nonpolar solvents. Sequential extraction has been the most efficient way to extract pinosylvin, since the lipophilic compounds have already been removed. It has been calculated that the purity of pinosylvin was high $(16 \%$, w/w) with sequential extraction. On the other hand, the yields in hot-water extracts were much lower than obtained in extraction with polar solvents. It was noticed that methanolysis enabled isolation of high-molar-mass compounds in the water extracts, which had been assumed to be polymeric or oligomeric hemicelluloses. When alkaline carbonate or hydroxide solutions 
are needed in extraction processes applied conditions, it may limit the use of such solutions in industrial applications.

Without seasoning, fresh woods from Norway spruce (P. abies) and bark, phloem, and heartwood and from Scots pine ( $P$. sylvestris) have been identified to contain lactic, citric, succinic, and adipic acids, which are considered as source chemicals in the biopolymer industry. The total acid concentration and specifically the amounts of acetic and succinic acids in fluids of bark, phloem, and heartwood of pine were $58.4 \mathrm{~g} / \mathrm{kg}$ and $3.5-6.9 \mathrm{~g} / \mathrm{kg}$, respectively. In spruce, the most dominant acids were $l$-lactic and $l$-malic acids. Traditionally, disassembling of trees for lignin degrading occurs with peroxidases and laccases enzymes. However, biological pretreatment of organic material is done with microorganisms, which inter alia can be yeast or brown-, white-, and soft-rot fungi (Isroi et al. 2011).

In biological processes, the starting wood material may also be treated by hydrolyzation with a strong mineral acid such as sulfuric acid. In that case, cellulose degrades to hexoses. Simultaneously, the wood hemicelluloses degrade to acetic acid and pentose, which are further changed to furans with an extension reaction. Thereafter, the reaction goes to furfural and other wood-based compounds. Furthermore, wood lignin goes to phenols and thereafter to phenolic compounds of low molecular weights (Balat 2011).

Lignocelluloses can be processed to biochemicals and fuels with pretreatment, hydrolysis, fermentation, and product separation (Alvira et al. 2010; Kim et al. 2004; Lee et al. 2002; Mosier et al. 2005). Currently, lignocelluloses are converted via saccharification followed by biochemical or catalytic process to sugars. The process is time-consuming because it still needs either acid or enzyme hydrolysis.

\section{Syneregistic effects of compounds from Scots pine (Pinus sylvestris) and Norway spruce (Picea abies)}

Antibacterial effect can derive from various compounds with antibacterial properties or from a synergistic effect of several compounds (Metsämuuronen and Sirén 2014). The recent research (Vainio-Kaila 2017) showed that generally pine is more antibacterial than spruce, although spruce is also found to have antibacterial effects against most bacterial strains. The extracts of Scots pine and Norway spruce stem, bark, roots, leaves and needles contain both phenolic extracts and essential oils which are bacteriostatic against several bacteria. Extracts from several other wood species besides Scots pine and Norway spruce have been studied in regard to their health effects.

In the case of tuberculosis, several natural compounds of low mammalian toxicity and strong in vitro activity exist (Pauli and Schilcher 2004). In addition, for first time promising antibacterial and antifungal effects of epidihydropinidine (Fyhrquist et al. 2019), which is the major piperidine alkaloid in the needles and bark of Norway spruce ( $P$. abies) showed inhibitory against bacterial and fungal strains with the lowest MIC value of $5.37 \mathrm{mg} \mathrm{L}^{-1}$ against $P$. aeruginosa, E. faecalis, Candida glabrata, and $C$. albicans. In addition, for epidihydropinidine (Fyhrquist et al. 2019), which is the major piperidine alkaloid in the needles and bark of Norway spruce $(P$. abies) showed mild inhibitory against bacterial and fungal strains with the lowest MIC value of $5.37 \mathrm{mg} \mathrm{L}^{-1}$ against $P$. aeruginosa, E. faecalis, $C$. glabrata, and C. albicans.

\section{Summary}

Scots pine (P. sylvestris) and Norway spruce (P. abies) stem, bark, roots, and needles contain several phenolic secondary metabolic compounds that exhibit antibacterial activity against several microbes. Most of them are produced via the phenylpropanoid pathway by the involvement of several plant enzymes, synthases, transferases, reductases, and hydroxylases.

Flavonols and their derivatives are among the most abundant flavonoids in both Scots pine (P. sylvestris) and Norway spruce. From stilbenes, Norway spruce (P. abies) contains resveratrol and its derivatives, whereas Scots pine ( $P$. sylvestris) contains different pinosylvins. The compounds having MIC values of $10 \mathrm{mg} \mathrm{L}^{-1}$ or less have been recognised as potential new medicines (Ríos and Recio 2005). Such compounds found in Scots pine (P. sylvestris) and Norway spruce (P. abies) are methylated and acylated derivatives of the flavonols quercetin, kaempferol, gallic acid, and methyl ester of gallic acid. The activity of the compounds has in general been higher against Grampositive bacteria than Gram-negative bacteria. The 
flavone, apigenin has been reported to be the most active compound against Gram-negative bacteria with MIC values ranging from 4 to $128 \mathrm{mg} \mathrm{L}^{-1}$.

Synergistic effects between individual compounds have been observed to increase their activity, which is comprehended through the multi-component defense system of the plants. There are several other less antibacterial compounds in softwoods (Scots pine, $P$. sylvestris and Norway spruce, $P$. abies) that in combination with others can be useful as antibacterial agents. Apart from drugs, natural antibacterial compounds may be exploited in the protection of food or different surfaces. For example, protecatechuic acid has been observed to effectively inhibit the growth of food poisoning bacteria B. cereus, E. coli, S. typhimurium, and L. monocytogenes. Most woodderived materials (branches, roots, bark, needles, and stems) containing valuable metabolites are discharged. However, utilization of these materials is difficult. High yields of highly valuable compounds are required in order for it to be economical to collect and transport these tissues, to extract, and to purify the compounds. The metabolite yield can also be affected by the delay between harvesting and processing.

Acknowledgements Open access funding provided by University of Helsinki including Helsinki University Central Hospital.

Open Access This article is distributed under the terms of the Creative Commons Attribution 4.0 International License (http:// creativecommons.org/licenses/by/4.0/), which permits unrestricted use, distribution, and reproduction in any medium, provided you give appropriate credit to the original author(s) and the source, provide a link to the Creative Commons license, and indicate if changes were made.

\section{References}

Akiyama H, Fujii K, Yamasaki O, Oono T, Iwatsuki K (2001) Antibacterial action of several tannins against Staphylococcus aureus. J Antimicrob Chemother 48:487-491. https://doi.org/10.1093/jac/48.4.487

Almagro L, Belchí-Navarro S, Sabater-Jara AB, Vera-Urbina JC, Sellés-Marchart S, Bru R, Angeles Pedreño M (2013) Bioproduction of trans-resveratrol from grapevine cell cultures. In: Ramawat K, Mérillon JM (eds) Natural products. Springer, Berlin. https://doi.org/10.1007/978-3642-22144-6_54
Almeida AAP, Naghetini CC, Santos VR, Antonio AG, Farah A A, Glória MBA (2012) Influence of natural coffee compounds, coffee extracts and increased levels of caffeine on the inhibition of Streptococcus mutans. Food Res Int 49:459-461. https://doi.org/10.1016/j.foodres.2012.07. 026

Alvira P, Tomás-Pejó E, Ballesteros M, Negro MJ (2010) Pretreatment technologies for an efficient bioethanol production process based on enzymatic hydrolysis: a review. Bioresour Technol 101:4851-4861. https://doi.org/10. 1016/j.biortech.2009.11.093

Al-Zahrami SHM (2012) Antibacterial activities of gallic acid and gallic acid methyl ester on methicillin-resistant Staphylococcus aureus. J Am Sci 8:7-12

An J, Zuo GY, Hao XY, Wang GC, Li ZS (2011) Antibacterial and synergy of a flavanonol rhamnoside with antibiotics against clinical isolates of methicillin-resistant Staphylococcus aureus (MRSA). Phytomedicine 18:990-993. https://doi.org/10.1016/j.phymed.2011.02.013

Antonova GF, Zheleznichenko TV, Stasove VV (2011) Changes in content and composition of phenolic acids during growth of xylem cells of Scots pine. Russ J Dev Biol 42:238-246. https://doi.org/10.1007/s11183-005-0013-x

Arima H, Ashida H, Danno G (2002) Rutin-enhanced antibacterial activities of flavonoids against Bacillus cereus and Salmonella enteritidis. Biosci Biotechnol Biochem 66:1009-1014. https://doi.org/10.1271/bbb.66.1009

Balat M (2011) Production of bioethanol from lignocellulosic materials via the biochemical pathway: a review. Energy Convers Manag 52:858-875. https://doi.org/10.1016/j. enconman.2010.08.013

Basile A, Giordano S, López-Sáez JA, Cobianchi RC (1999) Antibacterial activity of pure flavonoids isolated from mosses. Phytochemistry 52:1479-1482. https://doi.org/10. 1016/S0031-9422(99)00286-1

Bastianetto S, Ménard C, Quirion R (2015) Neuroprotective action of pine. Biochimica et Biophysica (BBA) Acta Mol Basis Dis 1852:1195-1201. https://doi.org/10.1016/j. bbadis.2014.09.011

Beninger CW, Abou-Zaid MM (1997) Flavonol glycosides from four pine species that inhibit early instar gypsy moth (Lepidoptera: Lymantriidae) development. Biochem Syst Ecol 25:505-512. https://doi.org/10.1016/S03051978(97)00034-3

Berg S (2014) Technology and systems for stump harvesting with low ground disturbance. Dissertation, University of Umeå

Boden S, Kahle HP, von Wilpert K, Spiecker H (2014) Resilience of Norway spruce (Picea abies (L.) Karst) growth to changing climatic conditions in Southwest Germany. For Ecol Man 315:12-21. https://doi.org/10.1016/j.foreco. 2013.12.015

Böke N, Sirén H, Petrik LF (2015) Fungal biofermentation of pine bark to produce organic acids and their identification by use of capillary electrophoresis technique. Ind Crops Prod 67:41-48. https://doi.org/10.1016/j.indcrop.2015.01. 020

Bonacorsi C, Raddi MSG, da Fonseca LM, Da Fonseca LM, Sannomiya M, Vilegas W (2012) Effect of Byrsonima crassa and phenolic constituents on Helicobacter pylori- 
induced neutrophis oxidative burst. Int $\mathrm{J}$ Mol Sci 13:133-141. https://doi.org/10.3390/ijms13010133

Cassidy A, Hanley B, Lamuela-Raventos RM (2000) Isoflavones, lignans and stilbenes-origins, metabolism and potential importance to human health. J Sci Food Agric 80:1044-1062. https://doi.org/10.1002/(SICI)10970010(20000515)80:7\%3c1044:AID-JSFA586\%3e3.0. $\mathrm{CO} ; 2-\mathrm{N}$

Catteau L, Zhu L, Van Bambeke F, Quetin-Leclercq J (2018) Natural and hemi-synthetic pentacyclic triterpenes as antimicrobials and resistance modifying agents against Staphylococcus aureus: a review. Phytochem Rev 17:1129-1163. https://doi.org/10.1007/s11101-018-95642

Chao C, Yin M (2009) Antibacterial effects of roselle calyx extracts and protocatechuic acid in ground beef and apple juice. Foodborne Pathog Dis 6:201-206. https://doi.org/10. 1089/fpd.2008.0187

Chen H, Li Q, Shuford CM, Liu J, Muddiman DC, Sederoff RR, Chiang VL (2011) Membrane protein complexes catalyze both 4- and 3-hydroxylation of cinnamic acid derivatives in monolignol biosynthesis. PNAS 27:21253-21258. https:// doi.org/10.1073/pnas.1116416109

Cheng AX, Han XJ, Wu YF, Lou HX (2014) The function and catalysis of 2-oxoglutarate-dependent oxygenases involved in plant flavonoid biosynthesis. Int $\mathrm{J}$ Mol Sci 15:1080-1095. https://doi.org/10.3390/ijms15011080

Chiron H, Drouet A, Claudot A, Eckerskorn C, Trost M, Heller W, Ernst D, Sandermann H Jr (2000) Molecular cloning and functional expression of a stress-induced multifunctional $O$-methyltransferase with pinosylvin methyltransferase activity from Scots pine (Pinus sylvestris L.). Plant Mol Biol 44:733-745

Chiron H, Drouet A, Ernst D, Sandermann H (2001) Pinus ozone- and fungi-inducible pinosylvin-3-O-methyltransferase gene PMT and use of promoter and/or gene to produce pathogen-resistant plants. WO 2001059139.2001. https://doi.org/10.3390/11010103

Chong J, Poutaraud A, Hugueney P (2009) Metabolism and roles of stilbenes in plants. Plant Sci 177:143-155

Ćirić A, Karioti A, Glamočlija J, Skaltsa M, Soković H (2011) Antibacterial activity of secondary metabolites isolated from Centaurea spuneri Boiss. and Heldr. J Serb Chem Soc 76:27-34. https://doi.org/10.2298/JSC100127008C

Conde E, Díaz-Reinoso B, Moure A, Hemming J, Willför SM, Domínguez H, Parajó JC (2013) Extraction of phenolic and lipophilic compounds from Pinus Piaster knots and stemwood by supercritical $\mathrm{CO}_{2}$. BioResources 8:2047-2063

Cowan MM (1999) Plant products as antimicrobial agents. Clin Microbiol Rev 12:564-582. https://doi.org/10.1128/CMR. 12.4.564

Cushnie TPT, Lamb AJ (2010) Recent advances in understanding the antibacterial properties of flavonoids. Int $\mathrm{J}$ Antimicrob Agents 38:99-107. https://doi.org/10.1016/j. ijantimicag.2011.02.014

Cvikrová M, Malá J, Hrubcová M, Eder J, Foretová S (2008) Induced changes in phenolic acids and stilbenes in embryogenic cell cultures of Norway spruce by culture filtrate of Ascocalyx abietina. J Plant Dis Protect 115:57-62
Danielsson M, Lundén K, Elfstrand M, Hu J, Zhao T, Arnerup J, Ihrmark K, Swedjemark G, Borg-Karlson AK, Stenlid J (2011) Chemical and transcriptional responses of Norway spruce genotypes with different susceptibility to Heterobasidion spp. infection. BMC Plant Biol 11:154. https:// doi.org/10.1186/1471-2229-11-154

Dixon RA (2001) Natural products and plant disease resistance. Nature 411:843-847. https://doi.org/10.1038/35081178

Dixon RA, Xie D, Sharma SB (2005) Proanthocyanidins-a final frontier in flavonoid research. New Phytol 165:9-28. https://doi.org/10.1111/j.1469-8137.2004.01217.x

Eklund P, Sillanpää R, Sjöholm R (2002) Synthetic transformation of hydroxymatairesinol from Norway spruce (Picea abies) to 7-hydroxysecoisolariciresinol, (q)-lariciresinol and (q)-cyclolariciresinol. J Chem Soc Perkin Trans 16:1906-1910. https://doi.org/10.1039/B202493D

Eklund PC, Willför SM, Smeds AI, Sundell FJ, Sjöholm RE, Holmbom BR (2004) A new lariciresinol-type butyrolactone lignan derived from hydroxymatairesinol and its identification in spruce wood. J Nat Prod 67:927-931. https://doi.org/10.1021/np0340706

El Basyouni SZ, Chen D, Ibrahim RK, Neish AC, Towers GHN (1964) The biosynthesis of hydroxybenzoic acids in higher plants. Phytochemistry 3:485-492

El Sayed Bashandy H (2016) Flavonoid metabolomics in Gerbera hybrida and elucidation of complexity in the flavonoid biosynthetic pathway. Dissertation, University of Helsinki

Elegir G, Kindl A, Sadocco P, Orlandi M (2008) Development of antimicrobial cellulose packaging through laccase-mediated grafting of phenolic compounds. Enzym Microb Technol 43:84-92. https://doi.org/10.1016/j.enzmictec. 2007.10.003

Fang W, Hemming J, Reunanen M, Eklund P, Pineiro Enma C, Poljanšek I, Oven P, Willför S (2013) Evaluation of selective extraction methods for recovery of polyphenols from pine. Holzforschung 67:843-851. https://doi.org/10. 1515/hf-2013-0002

Feng S, Zeng W, Luo F, Zhao J, Yang Z, Sun Q (2010) Antibacterial activity of organic acids in aqueous extracts from pine needles (Pinus massoniana Lamb.). Food Sci Biotechnol 19:35-41. https://doi.org/10.1007/s10068-0100005-2

Fliegmann J, Schröder G, Schanz S, Britsch L, Schröder J (1992) Molecular analysis of chalcone and dihydropinosylvin synthase from Scots pine (Pinus sylvestris), and differential regulation of these and related enzyme activities in stressed plants. Plant Mol Biol 18:489-503

Flores-Sanchez IJ, Verpoorte R (2009) Plant polyketide synthases: a fascinating group of enzymes. Plant Phys Biochem 47:167-174. https://doi.org/10.1016/j.plaphy.2008. 11.005

Fujita M, Gang DR, Davin LB, Lewis NG (1999) Recombinant pinoresinol-lariciresinol reductases from western red cedar (Thuja plicata) catalyze opposite enantiospecific conversions. J Biol Chem 274:618-627

Fyhrquist P, Virjamo V, Hiltunen E, Julkunen-Tiitto R (2019) Epidihydropinidine, the main piperidine alkaloid compound of Norway spruce (Picea abies) shows promising antibacterial and anti-Candida activity. Fitoterapia 134:503-511. https://doi.org/10.1016/j.fitote.2018.12.015 
Gachon CMM, Langlois-Meurinne M, Saindrenan P (2005) Plant secondary metabolism glycosyltransferases: the emerging functional analysis. Trends Plant Sci 10:542-549. https://doi.org/10.1016/j.tplants.2005.09.007

Ganthaler A, Stöggl W, Mayr S, Kranner I, Schüler S, Wischnitzki E, Sehr EM, Fluch S, Trujillo-Moya C (2017) Association genetics of phenolic needle compounds in Norway spruce with variable susceptibility to needle bladder rust. Plant Mol Biol 94:229-251. https://doi.org/ 10.1007/s11103-017-0589-5

Gehlert R, Schöppner A, Kindl H (1990) Stilbene synthase from seedlings of Pinus sylvestris: purification and induction in response to fungal infection. Mol Plant Microbe Interact 3:444-449. https://doi.org/10.1094/MPMI-3-444

Gérardin P (2016) New alternatives for wood preservation based on thermal and chemical modification of wood-a review. Ann For Sci 73:559-570. https://doi.org/10.1007/s13595015-0531-4

Grunwald P (2017) Biocatalysis: biochemical fundamentals and applications, 2nd edn. World Scientific Publishing Europe, New Jersey, pp 219-224. ISBN 978-178-32-6907-5

Hakkila P (2012) Utilization of residual forest biomass. Technology and energy. Springer Series in Wood Science. Springer, New York. ISBN 978-3-642-74072-5

Hammerbacher A, Ralph SG, Bohlmann J, Fenning T, Gershenzon J, Schmidt A (2011) Biosynthesis of the major tetrahydroxystilbenes in spruce, astringin and isorhapontin, proceeds via resveratrol and is enhanced by fungal infection. Plant Phys 157:876-890

Harju A, Venäläinen M, Anttonen S, Viitanen H, Kainulainen P, Saranpää P, Vapaavuori E (2003) Chemical factors affecting the brown-rot decay resistance of Scots pine heartwood. Trees 17:263-268. https://doi.org/10.1007/ s00468-002-0233-Z

He F, Pan QH, Ying Shi Y, Duan CQ (2008) Biosynthesis and genetic regulation of proanthocyanidins in plants. Molecules 13:2674-2703. https://doi.org/10.3390/ molecules13102674

Hellström J, Mattila PH (2008) HPLC determination of extractable and unextractable proanthocyanidins in plant materials. J Agric Food Chem 56:7617-7624. https://doi. org/10.1021/jf801336s

Hipskind JD, Paiva NL (2000) Constitutive accumulation of a resveratrol-glucoside in transgenic alfalfa increases resistance to Phoma medicaginis. Mol Plant Microb Inter 13:551-562. https://doi.org/10.1094/MPMI.2000.13.5.551

Holmbom B (2011) Extraction and utilisation of non-structural wood and bark components. In: Alén R (ed) Biorefining of Forest Recources, 1st edn. Paper Engineers Association, Porvoo

Holmbom B, Eckerman C, Eklund P, Hemming J, Nisula L, Reunanen M, Sjöholm R, Sundberg A, Sundberg K, Willför S (2003) Knots in trees - A new rich source of lignans. Phytochem Rev 2:331. https://doi.org/10.1023/B:PHYT. 0000045493.95074.a8

Hovelstad H, Leirset I, Oyaas K, Fiksdahl A (2006) Screening analyses of pinosylvin stilbenes, resin acids and lignans in Norwegian conifers. Molecules 11:103-114. https://doi. org/10.3390/11010103

Ibewuike JC, Ogungbamila FO, Ogundaini AO, Okeke IN, Bohlin L (1997) Antiinflammatory and antibacterial activities of C-methylflavonols from Piliostigma thonningii. Phytother Res 11:281-284

Ibrahim RK, Bruneau A, Bantignies B (1998) Plant O-methyltransferases: molecular analysis, common signature and classification. Plant Mol Biol 36:1-10

Idowu TO, Ogundaini AO, Salau AO, Obuotor EM, Bezabih M, Abegazd BM (2010) Doubly linked, A-type proanthocyanidin trimer and other constituents of Ixora coccinea leaves and their antioxidant and antibacterial properties. Phytochemistry 71:2092-2098. https://doi.org/10.1016/j. phytochem.2010.08.018

Iriti M, Faoro F (2009) Chemical diversity and defence metabolism: how plants cope with pathogens and ozone pollution. Int J Mol Sci 10:3371-3399. https://doi.org/10.3390/ ijms 10083371

Ishikura N, Hayashida S, Tazaki K (1984) Biosynthesis of gallic and ellagic acids with 14C-labeled compounds in Acer and Rhus leaves. Bot Mag Tokyo 97:355-367. https://doi.org/ 10.1007/BF02488668

Isroi RM, Syamsiah S, Niklasson C, Cahyanto MN, Ludquist K, Taherzadeh MJ (2011) Biological pretreatment of lignocelluloses with white-rot fungi and its applications: a review. BioResources 6:5224-5259

Izumi H, Anderson IC, Killham K, Moore ERB (2008) Diversity of predominant endophytic bacteria in European deciduous and coniferous trees. Can J Microbiol 54:173-179. https:// doi.org/10.1139/W07-134

Jagannath AB, Crozier A (2010) Biochemistry, nutrition and pharmacology. In: Fraga CG (ed) Plant phenolics and human health, 1st edn. Wiley, New Jersey. ISBN 978-0470-28721-7

Jansson G, Danusevičius D, Grotehusman H, Kowalczyk J, Krajmerova D, Skrøppa T, Wolf H (2013) Norway Spruce (Picea abies (L.) H.Karst.). In: Pâques LE (ed) Forest tree breeding in Europe, 1st edn. Springer, Dordrecht. https:// doi.org/10.1007/978-94-007-6146-9_3

Janusz J, Pawlik A, Sulej J, Świderska-Burek U, Jarosz-Wilkołazka A, Paszczyński A (2017) Lignin degradation: microorganisms, enzymes involved, genomes analysis and evolution. FEMS Microbiol Rev 41:941-962. https://doi. org/10.1093/femsre/fux049

Jyske T, Laakso T, Latva-Mäenpää H, Tapanila T, Saranpää P (2014) Yield of stilbene glucosides from the bark of young and old Norway spruce stems. Biomass Bioenergy 71:216-227. https://doi.org/10.1016/j.biombioe.2014.10. 005

Kaffarnik F, Heller W, Hertkorn N, Sandermann H Jr (2005) Flavonol 3-O-glycoside hydroxycinnamoyltransferases from Scots pine (Pinus sylvestris L.). FEBS J 272:1415-1424. https://doi.org/10.1111/j.1742-4658. 2005.04574.x

Kähkönen MP, Hopia AI, Vuorela HJ, Rauha JP, Pihlaja K, Kujala TS, Heinonen M (1999) Antioxidant activity of plant extracts containing phenolic compounds. J Agric Food Chem 47:3954-3962. https://doi.org/10.1021/ jf9901461

Kanerva S, Kitunen V, Kiikkilä O, Loponen J, Smolander A (2006) Response of soil C and N transformations to tannin fractions originating from Scots pine and Norway spruce needles. Soil Biol Biochem 38:1364-1374. https://doi.org/ 10.1007/s00374-007-0234-6 
Kanerva S, Kitunen V, Loponen J, Smolander A (2008) Phenolic compounds and terpenes in soil organic horizon layers under silver birch, Norway spruce and Scots pine. Biol Fertil Soils 44:547-556. https://doi.org/10.1007/ s00374-007-0234-6

Karonen M, Hämäläinen M, Nieminen R, Klika KD, Loponen J, Ovcharenko VV, Moilanen E, Pihlaja K (2004) Phenolic extractives from the bark of Pinus sylvestris L. and their effects on inflammatory mediators nitric oxide and prostaglandin $E_{2}$. J Agric Food Chem 52:7532-7540. https:// doi.org/10.1021/jf048948q

Karppanen O, Venäläinen M, Harju A, Laakso T (2008) The effect of brown-rot decay on water adsorption and chemical composition of Scots pine heartwood. Ann For Sci 65:610. https://doi.org/10.1051/forest:2008035

Kawai S, Sugishita K, Ohashi H (1999) Identification of Thuja occidentalis lignans and its biosynthetic relationship. Phytochemistry 51:243-247. https://doi.org/10.1016/ S0031-9422(99)00004-7

Kim DY, Yim SC, Lee PC, Lee WC, Lee SY, Chang HN (2004) Batch and continuous fermentation of succinic acid from wood hydrolysate by Mannheimia succiniciproducens MBEL55E. Enzym Microb Technol 35:648-653. https:// doi.org/10.1016/j.enzmictec.2004.08.018

Kim B, Sung S, Chong Y, Lim Y, Ahn JH (2010) Plant flavonoid O-Methyltransferases: substrate specificity and application. J Plant Biol 53:321-329. https://doi.org/10.1007/ s12374-010-9126-7

Kodan A, Kuroda H, Sakai F (2002) A stilbene synthase from Japanese red pine (Pinus densiflora): implications for phytoalexin accumulation and down-regulation of flavonoid biosynthesis. Plant Biol 99:3335-3339. https://doi. org/10.1073/pnas.042698899

Koo H, Rosalen PL, Cury JA, Park YK, Bowen WH (2002) Effects of compounds found in propolis on Streptococcus mutans growth and on glucosyltransferase activity. Antimicrob Agents Chemother 46:1302-1309. https://doi. org/10.1128/AAC.46.5.1302-1309.2002

Koutaniemi S (2007) Lignin biosynthesis in Norway spruce: from a model system to the tree. Dissertation, University of Helsinki

Krajnc AU, Novak M, Felicijan M, Kraševec N, Lešnik M, Zupanec N, Komel R (2014) Antioxidative response patterns of Norway spruce bark to low-density Ceratocystis polonica inoculation. Trees 28:1145-1160

Kraus TEC, Dahlgren RA, Zasoski RJ (2003) Tannins in nutrient dynamics of forest ecosystems-a review. Plant Soil 256:41-66. https://doi.org/10.1023/A: 1026206511084

Krogell J, Holmbom B, Pranovich A, Hemming J, Willför SM (2012) Extraction and chemical characterization of Norway spruce inner and outer bark. Nordic Pulp Paper Res J 27:6-17

Kwasniewski SP, Claes L, Francois JP, Deleuze MS (2003) High level theoretical study of the structure and rotational barriers of trans-stilbene. J Chem Phys 118:7823-7836. https://doi.org/10.1063/1.1563617

Kwon M, Davin LB, Lewis NG (2001) In situ hybridization and immunolocalization of lignin reductases in woody tissues: implications for heartwood formation and other forms of vascular tissue preservation. Phytochemistry 57:899-914. https://doi.org/10.1016/S0031-9422(01)00108-X

Laavola M, Nieminen R, Leppänen T, Eckerman C, Holmbom B, Moilanen E (2015) Pinosylvin and monomethylpinosylvin, constituents of an extract from the knot of Pinus sylvestris, reduce inflammatory gene expression and inflammatory responses in vivo. J Agric Food Chem 63:3445-3453. https://doi.org/10.1021/jf504606m

Laracine-Pittet C, Lebreton P (1988) Flavonoid variability within Pinus sylvestris. Phytochemistry 1182(27):2663-2666

Larsson S, Lundgren L, Ohmart CP, Gref R (1992) Weak responses of pine sawfly larvae to high needle flavonoid concentrations in Scots pine. J Chem Ecol 18:271-282. https://doi.org/10.1007/BF00994231

Latva-Mäenpää H (2017) Bioactive and protective polyphenolics from roots and stumps of conifer trees (Norway spruce and Scots pine). Dissertation, University of Helsinki

Lavola A, Aphalo PJ, Lahti M, Julkunen-Tiitto R (2003) Nutrient availability and the effect of increasing UV-B radiation on secondary plant compounds in Scots pine. Environ Exp Bot 49:49-60. https://doi.org/10.1016/S00988472(02)00057-6

Lee PC, Lee SY, Hong SH, Chang H (2002) Isolation and characterization of a new succinic acid producing bacterium, Mannheimia succiniciproducens MBEL55E, from bovine rumen. Appl Microbiol Biotechnol 58:663-668. https://doi.org/10.1007/s00253-002-0935-6

Leppänen K, Spetz P, Pranovich A, Hartonen K, Kitunen V, Ilvesniemi H (2011) Pressurized hot water extraction of Norway spruce hemicelluloses using a flow-through system. Wood Sci Tech 45:223-236. https://doi.org/10.1007/ s00226-010-0320-Z

Li S, Niu X, Zahn S, Gershenzon J, Weston J, Schneider B (2008) Diastereomeric stilbene glucoside dimers from the bark of Norway spruce (Picea abies). Phytochemistry 69:772-782. https://doi.org/10.1016/j.phytochem.2007.08. 033

Li XB, Yang ZX, Yang L, Chen XL, Zhang K, Yang Q, Wu YM, Liu SB, Tao KS, Zhao MG (2012) Neuroprospective effects of flax lignan against NMDA-induced neurotoxicity in vitro. CNS Neurosci Ther 18:927-933. https://doi.org/ 10.1111/cns. 12003

Lieutier F, Brignolas F, Sauvard D, Yart A, Galet C, Brunet M, van de Sype H (2003) Intra- and inter-provenance variability in phloem phenols of Picea abies and relationship to a bark beetle associated fungus. Tree Physiol 23:247-256

Lim CG, Koffas MAG (2010) Bioavailability and recent advances in the bioactivity of flavonoid and stilbene compounds. Curr Org Chem 14:1727-1751. https://doi. org/10.2174/138527210792927654

Lindberg LE, Willför SM, Holmbom BR (2004) Antibacterial effects of knotwood extractives on paper mill bacteria. J Ind Microb Biotech 31:137-147. https://doi.org/10.1007/ s10295-004-0132-y

Liu H, Orjala J, Sticher O, Rali T (1999) Acylated flavonol glycosides from leaves of Stenochlaena palustris. J Nat Prod 62:70-75. https://doi.org/10.1021/np980179f

Long H, Li X, Wang H, Jia J (2013) Biomass resources and their bioenergy potential estimation: a review. Renew Sustain 
Energy Rev 26:344-352. https://doi.org/10.1016/j.rser. 2013.05.035

Lou Z, Wang H, Rao S, Sun J, Ma C, Li J (2012) p-Coumaric acid kills bacteria through dual damage mechanisms. Food Control 25:550-554. https://doi.org/10.1016/j.foodcont. 2011.11.022

Mageroy HM, Parent G, Germanos G, Giguere I, Delvas N, Maaroufi H, Bauce E, Bohlmann J, Mackay JJ (2015) Expression of the $\beta$-glucosidase gene Pg $\beta$ glu-1 underpins natural resistance of white spruce against spruce budworm. Plant J 81:68-80. https://doi.org/10.1111/tpj.12699

Mageroy MH, Jancsik S, Yuen MMS, Fischer M, Withers SG, Paetz C, Schneider B, Mackay J, Bohlmann J (2017) A conifer UDP-sugar dependent glycosyltransferase contributes to acetophenone metabolism and defense against insects. Plant Physiol 175:641-651. https://doi.org/10. 1104/pp.17.00611

Maimoona A, Naeem I, Saddiqe Z, Jameel K (2011) A review on biological, nutraceutical and clinical aspects of French maritime pine bark extract. J Ethnopharmacol 133:261-277. https://doi.org/10.1016/j.jep.2010.10.041

Malá J, Hrubcová M, Máchová $\mathrm{P}$, Cvrčková $\mathrm{H}$, Martincová $\mathrm{O}$, Cvikrová M (2011) Changes in phenolic acids and stilbenes induced in embryogenic cell cultures of Norway spruce by two fractions of Sirococcus strobilinus mycelia. J For Sci 57:1-7

Malterud KE, Bremnes TE, Faegri A, Moe T, Sandanger Dugstad EK, Anthonsen T, Henriksen LM (1985) Flavonoids from the wood of Salix caprea as inhibitors of wood-destroying fungi. J Nat Prod 48:559-563. https://doi.org/10. 1021/np50040a007

Mandalari G, Bennett RN, Bisignano GD, Trombetta D, Saija A, Faulds CB, Gasson MJ, Narbad A (2007) Antimicrobial activity of flavonoids extracted from bergamot (Citrus bergamia Risso) peel, a byproduct of the essential oil industry. J Appl Microbiol 103:2056-2064. https://doi.org/ 10.1111/j.1365-2672.2007.03456.x

Mantau U, Saal U, Prince K, Trombetta D, Saija A, Faulds CB, Gasson MJ, Narbad A (Eds) (2010) Real potential for changes in growth and use of EU forests. Final report 20th June 2010

Martini S, D’Addario C, Colacevich A, Focardi S, Borghini F, Santucci A, Figura N, Rossi C (2009) Antimicrobial activity against Helicobacter pylori strains and antioxidant properties of blackberry leaves (Rubus ulmifolius) and isolated compounds. Int J Antimicrob Agents 34:50-59. https://doi.org/10.1016/j.ijantimicag.2009.01.010

Martins S, Mussatto SI, Martinez-Avila G, Montañez-Saenz J, Aguilar CN, Teixeira JA (2011) Bioactive phenolic compounds: production and extraction by solid-state fermentation-a review. Biotechnol Adv 29:365-373. https://doi. org/10.1016/j.biotechadv.2011.01.008

Masek A, Chrzescijanska E, Latos M (2016) Determination of antioxidant activity of caffeic acid and $p$-coumaric acid by using electrochemical and spectrophotometric assays. Int $\mathrm{J}$ Electrochem Sci 11:10644-10658. https://doi.org/10. 20964/2016.12.73

Matthews S, Mila I, Scalbert A, Connelly DMX (1997) Extractable and non-extractable proanthocyanidins in barks. Phytochemistry 45:405-410. https://doi.org/10. 1016/S0031-9422(96)00873-4
Metacyc (2019) https://biocyc.org/META. Accessed 11 May 2019

Metsämuuronen S, Sirén H (2014) Antibacterial compounds in predominant trees in Finland-Review. J Bioprocess Biotechnol 4:1000167/1-1000167/13. https://doi.org/10. 4172/2155-9821.1000167

Min BR, Pinchak WE, Merkel R, Walker S, Tomita G, Anderson RC (2009) Comparative antimicrobial activity of tannin extracts from perennial plants on mastitis pathogens. Sci Res Essays 3:66-73

Mosier N, Wyman C, Dale B, Elander R, Lee YY, Holtzapple M, Ladisch M (2005) Features of promising technologies for pretreatment of lignocellulosic biomass. Bioresour Technol 96:673-686. https://doi.org/10.1016/j.biortech. 2004.06.025

Mulat DG, Latva-Mäenpää H, Koskela H, Pekka Saranpää P, Wähälä K (2014) Rapid chemical characterisation of stilbenes in the root bark of Norway spruce by off-line HPLC/ DAD-NMR. Phytochem Anal 25:529-536. https://doi.org/ 10.1002/pca. 2523

Münzenberger B, Heilemann J, Strack D, Kottke I, Oberwinkler F (1990) Phenolics of mycorrhizas and non-mycorrhizal roots of Norway spruce. Planta 182:142-148. https://doi. org/10.1007/BF00239996

Nascimento GGF, Locatelli J, Freita PC, Silve GL (2000) Antibacterial activity of plant extracts and phytochemicals on antibiotic-resistant bacteria. Braz $\mathrm{J}$ Microbiol 31:247-256. 83822000000400003

Naz S, Siddiqi R, Ahmad S, Rasool SA, Sayeed SA (2007) Antibacterial activity directed isolation of compounds from Punica granatum. J Food Sci 72:M341-M345. https://doi.org/10.1111/j.1750-3841.2007.00533.x

Nitta T, Arai T, Takamatsu H, Inatomi Y, Murata H, Ilnuma M, Tanaka T, Ito T, Asai F, Ilnuma M, Ibrahim F, Nakanishi T, Watabe K (2002) Antibacterial activity of extracts prepared from tropical and subtropical plants on methicillinresistant Staphylococcus aureus. J Health Sci 48:273-276. https://doi.org/10.1248/jhs.48.273

Öksüz S, Ayyildiz H, Johansson C (1984) 6-Methoxylated and C-glycosyl flavonoids from Centaurea species. J Nat Prod 47(5):902-903

Oleszek W, Stochmal A, Karolewski P, Simonet AM, Macias FA, Tava A (2002) Flavonoids from Pinus sylvestris needles and their variation in trees of different origin grown for nearly a century at the same area. Biochem Syst Ecol 30:1011-1022. https://doi.org/10.1016/S03051978(02)00060-1

Ondrias K, Stasko A, Hromadova M, Suchy V, Nagy M (1997) Pinobanksin inhibits peroxidation of low density lipoprotein and it has electron donor properties reducing $\alpha$-tocopherol radicals. Pharmazie 52:566-567

Ossipov V, Salminen J, Ossipova S, Haukioja E, Pihlaja K (2003) Gallic acid and hydrolysable tannins are formed in birch leaves from an intermediate compound of the shikimate pathway. Biochem Syst Ecol 31:3-16. https://doi.org/ 10.1016/S0305-1978(02)00081-9

Otsuka N, Liu M, Shiota S, Ogawa W, Kuroda T, Hatano T, Tsuchiya T (2008) Anti-methicillin resistant Staphylococcus aureus (MRSA) compounds isolated from Laurus 
nobilis. Biol Pharm Bull 31:1794-1797. https://doi.org/10. 1248/bpb.31.1794

Paasela T (2017) The stilbene biosynthetic pathway and its regulation in Scots pine, Dissertation, University of Helsinki

Paasela T, Lim KJ, Pietiäinen M, Teeri TH (2017) The $O$ methyltransferase PMT2 mediates methylation of pinosylvin in Scots pine. New Phytol 214:1537-1550. https:// doi.org/10.1111/nph.14480

Pan H, Lundgren LN (1995) Phenolic extractives from root bark of Picea abies. Phytochemistry 39:1423-1428. https://doi. org/10.1016/0031-9422(95)00144-V

Pan H, Lundgren LN (1996) Phenolics from inner bark of Pinus sylvestris. Phytochemistry 42:1185-1189. https://doi.org/ 10.1016/0031-9422(96)00122-7

Pauli A, Schilcher H (2004) Specific selection of essential oil compounds for treatment of children's infection diseases. Pharmaceuticals (Basel) 1:1-30. https://doi.org/10.3390/ ph1010001

Paulo L, Ferreira S, Gallardo E, Queiroz JA, Domingues F (2010) Antimicrobial activity and effects of resveratrol on human pathogenic bacteria. World J Microbiol Biotechnol 26:1533-1538. https://doi.org/10.1007/s11274-010-03257

Paulo L, Oleastro M, Gallardo E, Queiroz JA, Domingues F (2011) Anti-Helicobacter pylori and urease inhibitory activities of resveratrol and red wine. Food Res Int 44:964-969. https://doi.org/10.1016/j.foodres.2011.02. 017

Pezet R, Gindro K, Viret O, Richter H (2004) Effects of resveratrol, viniferins and pterostilbene on Plasmopara viticola zoospore mobility and disease development. Vitis 43:145-148

Philippoussis A, Diamantopoulou P, Papadopoulou K, Lakhtar H, Roussos S, Parissopoulos G, Papanikolaou S (2011) Biomass, laccase and endoglucanase production by Lentinula edodes during solid state fermentation of reed grass, bean stalks and wheat straw residues. World J Microbio Biotech 27:285-297. https://doi.org/10.1007/ s11274-010-0458-8

Pietarinen S, Willför S, Ahotupa M, Hemming JE, Holmbom BR (2006) Knotwood and bark extracts: strong antioxidants from waste materials. J Wood Sci 52:436-444. https://doi.org/10.1007/s10086-005-0780-1

Piispanen R, Willför S, Saranpää P (2008) Variation of lignans in Norway spruce (Picea abies [L.] Karst.) knotwood: within-stem variation and the effect of fertilisation at two experimental sites in Finland. Trees 22:317-328. https:// doi.org/10.1515/hf-2013-0020

Pirttilä AM, Laukkanen H, Pospiech H, Myllylä R, Hohtola A (2000) Detection of intracellular bacteria in the buds of Scotch pine (Pinus sylvestris L.) by in situ hybridization. Appl Environ Microbiol 66:3073-3077. https://doi.org/10. 1128/AEM.66.7.3073-3077.2000

Pirttilä AM, Podolich O, Koskimäki JJ, Hohtola E, Hohtola A (2008) Role of origin and endophyte infection in browning of bud-derived tissue cultures of Scots pine (Pinus sylvestris L.). Plant Cell Tissue Organ Cult 95:47-55. https:// doi.org/10.1007/s11240-008-9413-x

Plant Metabolic Pathway Databases (2012) http://www. plantcyc.org/. Accessed 21 Dec 2018
Plumed-Ferrer C, Väkeväinen K, Komulainen H, Rautiainen M, Smeds A, Raitanen JE, Eklund P, Willför S, Alakomi HL, Saarela M, von Wright A (2013) The antimicrobial effects of wood associated polyphenols on food pathogens and spoilage organisms. Int J Food Microbiol 164:99-107. https://doi.org/10.1016/j.ijfoodmicro.2013.04.001

Pranovich A, Holmbom B, Willför S (2015) Two-stage hotwater extraction of galactoglucomannans from spruce wood. J Wood Chem Technol 36:140-156. https://doi.org/ 10.1080/02773813.2015.1104543

Puupponen-Pimiä R, Nohynek L, Meier C, Kähkönen M, Heinonen M, Hopia A, Oksman-Caldentey KM (2001) Antimicrobial properties of phenolic compounds from berries. J Appl Microbiol 90:494-507. https://doi.org/10. 1046/j.1365-2672.2001.01271.x

Rauha J, Remes S, Heinonen M, Hopia A, Kähkönen M, Kujala T, Pihlaja K, Vuorela H, Vuorela P (2000) Antimicrobial effects of Finnish plant extracts containing flavonoids and other phenolic compounds. Int J Food Microbiol 56:3-12. https://doi.org/10.1016/S0168-1605(00)00218-X

Reddy MSS, Chen F, Shadle G, Jackson L, Aljoe H, Dixon RA (2005) Targeted down-regulation of cytochrome P450 enzymes for forage quality improvement in alfalfa (Medicago stiva L.). PNAS 102:16573-16578. https://doi.org/ 10.1073/pnas.0505749102

Reinisalo M, Kårlund A, Koskela A, Kaarniranta K, Karjalainen RO (2015) Polyphenol stilbenes: molecular mechanisms of defence against oxidative stress and aging-related diseases. Oxid Med Cell Longev 340520:1-24. https://doi.org/10. 1155/2015/340520

Robledo A, Aguilera-Carbó A, Rodriguez R, Martinez JL, Garza Y, Cristobal N, Aguilar CN (2008) Ellagic acid production by Aspergillus niger in solid state fermentation of pomegranate residues. J Ind Microbiol Biotechnol 35:507-513. https://doi.org/10.1007/s10295-008-0309-x

Rice-Evans CA, Miller NJ, Paganga G (1996) Structure-antioxidant activity relationship of flavonoids and phenolic acids. Free Radic Biol Med 20:933-956. https://doi.org/10. 1016/0891-5849(95)02227-9

Ríos JL, Recio MC (2005) Medicinal plants and antimicrobial activity. J Ethnopharmacol 100:80-84. https://doi.org/10. 1016/j.jep.2005.04.025

Rodríguez Vaquero MJ, Fernández PAA, de Nadra MCM (2011) Effect of phenolic compound mixtures on the viability of Listeria monocytogenes in meat model. Food Technol Biotechnol 49:83-88

Roitto M, Rautio P, Markkola A, Julkunen-Tiitto R, Varama M, Saravesi K, Tuomi J (2008) Induced accumulation of phenolics and sawfly performance in Scots pine in response to previous defoliation. Tree Physiol 29:207-216. https:// doi.org/10.1093/treephys/tpn017

Rosemann D, Heller W, Sandermann H (1991) Biochemical plant responses to ozone, II. Induction of stilbene biosynthesis in Scots pine (Pinus sylvestris L.) seedlings. Plant Phys 97:1280-1286. https://doi.org/10.1104/pp.97.4.1280

Routa J, Brännström H, Anttila P, Mäkinen M, Jänis J, Asikainen A (2017) Wood extractives of Finnish pine, spruce and birch—availability and optimal sources of compounds-a literature review. Natural resources and bioeconomy studies. Report series 73/2017, p 55. http://urn.fi/URN: ISBN:978-952-326-495-3 
Royer M, Haude R, Viana Y, Stevanovic T (2012) Non-wood forest products based on extractives. A new opportunity for Canadian forest industry, part 2: softwood forest species. J Food Res 1:8-45. https://doi.org/10.5539/jfr.v1n3p8

Sandermann H, Ernst D, Drouet A, Chiron H (2000) Protein and DNA sequence for pinosylvin- $\beta$ - $O$-methyltransferase (PMT), EP0979874, 16 Feb 2000

Sarıkahya NB, Pekmez M, Arda N, Kayce P, Yavasoglu NUK, Kirizigül S (2011) Isolation and characterization of biologically active glycosides from endemic Cephalaria species in Anatolia. Phytochem Lett 4:415-420. https://doi. org/10.1016/j.phytol.2011.05.006

Saxena S (2015) Applied microbiology. Springer, New Delhi. ISBN 978-81-322-2259-0

Schultz TP, Nicola DD (2000) Naturally durable heartwood; evidence for a proposed dual defensive function of extractives. Phytochemistry 54:47-52. https://doi.org/10. 1016/S0031-9422(99)00622-6

Schnitzler J, Jungblut TP, Heller W, Köfferlein M, Langebartels C, Heller W, Sandermann H Jr (1996) Tissue localization of UV-B-screening pigments and chalcone synthase mRNA in needles of Scots pine seedlings. New Phytol 132:247-258. https://doi.org/10.1007/s004680050072

Schnitzler J, Jungblut TP, Feicht C et al (1997) UV-B induction of flavonoid biosynthesis in Scots pine (Pinus sylvestris L.) seedlings. Trees Struct Funct 11:162-168. https://doi.org/ $10.1007 / \mathrm{s} 004680050072$

Shah J (2003) The salicylic acid loop in plant defense. Curr Opin Plant Biol 6:365-371. https://doi.org/10.1016/S13695266(03)00058-X

Shan B, Cai YZ, Brooks JD, Corke H (2008) Antibacterial properties of Polygonum cuspidatum roots and their major bioactive constituents. Food Chem 109:530-537. https:// doi.org/10.1016/j.foodchem.2007.12.064

Shein IV, Andreeva ON, Polyakova GG, Zrazhevskaya GK (2003) Effect of pine callus elicitation by the Fusarium strains of various pathogenicity on the content of phenolic compounds. Russ J Physiol 50:710-715. https://doi.org/10. 1023/A:1025688023862

Si CL, An LL, Xie DN, Liu CY, Chen XQ, Wang GH, Dan Huo D, Yang QL, Hong YM (2016) New acylated flavonol glycosides with antibacterial activity from root barks of Sophora japonica. Wood Sci Technol 50:645-659. https:// doi.org/10.1007/s00226-016-0809-1

Silva JRA, Rezende CM, Pinto AC, Amaral ACF (2010) Cytotoxicity and antibacterial studies of iridoids and phenolic compounds isolated from the latex of Himatanthus sucuuba. Afr J Biotechnol 9:7357-7360. https://doi.org/10. 5897/AJB 10.345

Sirén H, Kaijanen L, Kaartinen S, Väre M, Riikonen P, Jernström E (2014) Determination of statins by gas chromatography-EI/MRM-tandem mass spectrometry: fermentation of pine samples with Pleurotus ostreatus. J Anal Bioanal Chem 94:196-202. https://doi.org/10.1016/ j.jpba.2014.01.018

Sirén H, Riikonen P, Yang G, Petton A, Paarvio A, Böke N (2015) Hydrophilic compounds in liquids of enzymatic hydrolysed spruce and pine biomass. Anal Biochem 485:86-96. https://doi.org/10.1016/j.ab.2015.06.004

Slimestad R, Francis GW, Andersen ØM (1999) Directed search for plant constituents: a case study concerning flavonoids in Norway spruce. Euphytica 105:119-123. https://doi.org/ 10.1023/A:1003473612531

Smeds AI, Eklund PC, Willför SM (2018) Characterization of high-molar-mass fractions in a Scots pine (Pinus sylvestris L.) knotwood ethanol extract. Holzforschung 72:201-213. https://doi.org/10.1515/hf-2017-0079

Smolander A, Kanerva S, Adamczyk B, Kitunen V (2012) Nitrogen transformations in boreal forest soils-Does composition of plant secondary compounds give any explanations? Plant Soil 350:1-26. https://doi.org/10.1007/ s11104-011-0895-7

Soccol CR, da Costa ESF, Letti LA Jr, Grace S, Karp SG, Woiciechowski AL, de Souza Vandenberghe LP (2017) Recent development and innovations in solid state fermentation. Biotechnol Res Innov 1:52-71. https://doi.org/ 10.1016/j.biori.2017.01.002

Solhaug KA (1990) Stilbene glucosides in bark and needles from Picea species. Scand J Res 5:59-67. https://doi.org/ 10.1080/02827589009382593

Spigno G, Tramelli L, De Faveri D M (2007) Effects of extraction time, temperature and solvent on concentration and antioxidant activity of grape marc phenolics. J Food Eng 81:200-208. https://doi.org/10.1016/j.jfoodeng.2006. 10.021

Stapleton PD, Shah S, Hamilton-Miller JMT, Hara Y, Nagaoka Y, Kumagai A, Uesato S, Taylor PW (2004) Anti-Staphylococcus aureus activity and oxacillin resistance modulating capacity of 3-O-acylcatechins. Int $\mathrm{J}$ Antimicrob Agents 24:374-380. https://doi.org/10.1016/j.ijantimicag. 2004.03.024

Stapleton PD, Shah S, Ehlert K, Hara Y, Taylor PW (2007) The $\beta$-lactam-resistance modifier (-) - epicatechin gallate alters the architecture of the cell wall of Staphylococcus aureus. Microbiology 153:2093-2103. https://doi.org/10. 1099/mic.0.2007/007807-0

Stevanovic T, Diouf PN, Garcia-Perez ME (2009) Bioactive polyphenols from healthy diets and forest biomass. Curr Nutr Food Sci 5:264-295. https://doi.org/10.2174/ 157340109790218067

Stolter C, Niemelä P, Ball JP, Julkunen-Tiitto R, Vanhatalo A, Danell K, Varvikko T, Ganzhorn JU (2009) Comparison of plant secondary metabolites and digestibility of three different boreal coniferous trees. Basic Appl Ecol 10:19-26. https://doi.org/10.1016/j.baae.2007.12.001

Strzelczyk E, Li CY (2000) Bacterial endobionts in the big nonmycorrhizal roots of Scots pine (Pinus sylvestris L.). J Microbiol Res 155:229-232

Suzuki S, Umezawa T (2007) Biosynthesis of lignans and norlignans. J Wood Sci 53:273-284. https://doi.org/10. 1007/s10086-007-0892-x

Szekeres T, Fritzer-Szekeres M, Saiko P, Jäger W (2010) Resveratrol and resveratrol analogues-structure-activity relationship. Pharm Res 27:1042-1048. https://doi.org/ 10.1007/s11095-010-0090-1

Tanase C, Talmaciu AI, Bâra IC (2018) New aspects of biomass waste valorization Spruce bark crude extracts as plant growth regulators. BioResources 13(2):3994-4007. https:// doi.org/10.15376/biores.13.2.3994-4007

Topal F, Nar M, Gocer H, Kalin P, Kocyigit UM, Gülçin I, Alwasel SH (2016) Antioxidant activity of taxifolin: an activity-structure relationship. J Enzym Inhib Med Chem 
31:674-683. https://doi.org/10.3109/14756366.2015. 1057723

Treutter D (2006) Significance of flavonoids in plant resistance: a review. Environ Chem Lett 4(3):147-157. https://doi.org/ 10.1007/s10311-006-0068-8

Tsuchiya H, Sato M, Miyazaki T, Fujiwara S, Tanigaki S, Ohyama M, Tanaka T, Iinuma M (1996) Comparative study on the antibacterial activity of phytochemical flavanones against methicillin resistant Staphylococcus aureus. J Ethnopharmacol 50:27-34. https://doi.org/10.1016/ 0378-8741(96)85514-0

Turtola S, Sallas L, Holopainen JK, Julkunen-Tiitto R, Kainulainen P (2006) Long-term exposure to enhanced UV-B radiation has no significant effects on growth or secondary compounds of outdoor grown Scots pine and Norway spruce seedlings. Env Pol 144:166-171. https://doi.org/10. 1016/j.envpol.2005.12.025

Umezawa T (2003) Diversity in lignan biosynthesis. Phytochem Rev 2:371-390. https://doi.org/10.1023/B:PHYT. 0000045487.02836 .32

Vainio-Kaila T (2017) Antibacterial properties of Scots pine and Norway spruce. Doctoral dissertation, Aalto University publication series, 179

Vainio-Kaila T, Zhang X, Hänninen T, Kyyhkynen A, Johansson LS, Willför S, Österberg M, Siitonen A, Rautkari L (2017) Antibacterial effects of wood structural components and extractives from Pinus sylvestris and Picea abies on methicillin-resistant Staphylococcus aureus and Escherichia coli. BioResources 12:7601-7614. https://doi.org/10. 15376/biores.12.4.7601-7614

Välimaa A, Honkalampi-Hämäläinen U, Pietarinen S, Willför S, Holmbom B, von Wright A (2007) Antimicrobial and cytotoxic knotwood extracts and related pure compounds and their effects on food associated microorganisms. Int $\mathrm{J}$ Food Microbiol 115:235-243. https://doi.org/10.1016/j. ijfoodmicro.2006.10.031

van der Watt E, Pretorius JC (2001) Purification and identification of active antibacterial components in Carpobrotus edulis L. J Ethnopharmacol 76:87-91. https://doi.org/10. 1016/S0378-8741(01)00197-0

van Puyvelde L, de Kimpe N, Costa J, Munyjabo V, Nyirankuliza S, Hakizamungu E, Schamp N (1989) Isolation of flavonoids and a chalcone from Helichrysum odoratissimum and synthesis of helichrysetin. J Nat Prod 52:629-633

Venäläinen M, Harju AM, Saranpää P, Kainulainen P, Tiitta M, Velling P (2004) The concentration of phenolics in brownrot decay resistant and susceptible Scots pine heartwood. Wood Sci Technol 38:109-118. https://doi.org/10.1007/ s00226-004-0226-8

Viiri H, Annila E, Niemelä P (2001) Induced responses in stilbenes and terpenes in fertilized Norway spruce after inoculation with blue-stain fungus Ceratocystis polonica. Trees 15:112-122. https://doi.org/10.1007/ s004680000082

Vogt T (2010) Phenylpropanoid biosynthesis. Mol Plant 3:2-20. https://doi.org/10.1093/mp/ssp106

Wan JF, Yuan JQ, Mei ZN, Yang XZ (2012) Phenolic glycosides from Boschniakia himalaica. Chin Chem Lett 23:579-582. https://doi.org/10.1016/j.cclet.2012.02.001
Wildermuth MC, Dewdney J, Wu G, Ausubel FM (2001) Isochorismate synthase is required to synthesize salicylic acid for plant defence. Nature 414:562-565. https://doi.org/10. 1038/417571a

Willför SM, Ahotupa MO, Hemming JE, Reunanen MHT, Eklund PC, Sjöholm RE, Eckerman CSE, Pohjamo SP, Holmbom BR (2003a) Antioxidant activity of knotwood extractives and phenolic compounds of selected tree species. J Agric Food Chem 51:7600-7606. https://doi.org/10. 1021/jf030445h

Willför S, Hemming J, Reunanen M, Eckerman C, Holmbom BR (2003b) Lignans and lipophilic extractives in Norway spruce knots and stemwoods. Holzforschung 57:27-36. https://doi.org/10.1515/HF.2003.005

Willför S, Hemming J, Reunanen M, Holmbom BR (2003c) Phenolic and lipophilic extractives in Scots pine knots and stemwood. Holzforschung 57:359-372. https://doi.org/10. 1515/HF.2003.054

Willför S, Nisula L, Hemming J, Reunanen M, Holmbom B (2004) Bioactive phenolic substances in industrially important tree species. Part 1 . Knots and stemwood of different spruce species. Holzforschung 58:335-344. https://doi.org/10.1515/HF.2004.052

Willför S, Eklund P, Sjöholm R, Reunanen M, Sillanpää R, von Schoultz S, Hemming J, Nisula L, Holmbom BR (2005) Bioactive phenolic substances in industrially important tree species. Part 4. Identification of two new 7-hydroxy divanillyl butyrolactol lignans in some spruce, fir, and pine species. Holzforschung 59:413-417. https://doi.org/10. 1515/HF.2005.067

Wink M (2003) Evolution of secondary metabolites from an ecological and molecular phylogenetic perspective. Phyt Chem 64:3-19. https://doi.org/10.1016/S00319422(03)00300-5

Winkel-Shirley B (2001) Flavonoid biosynthesis. A colourful model for genetics, biochemistry, cell biology, and biotechnology. Plant Physiol 126:485-493. https://doi.org/ 10.1104/pp.126.2.485

Xiao J (2017) Dietary flavonoid aglycones and their glycosides: Which show better biological significance? Crit Rev Food Sci Nutr 57:1874-1905. https://doi.org/10.1080/10408398. 2015.1032400

Xu BJ, Chang S K C (2007) A comparative study on phenolic profiles and antioxidant activities of legumes as affected by extraction solvents. J Food Sci 72:S159-S166. https://doi. org/10.1111/j.1750-3841.2006.00260.x

$\mathrm{Xu} \mathrm{X}$, Lee SF (2001) Activity of plant flavonoids against antibiotic-resistant bacteria. Phytother Res 15:39-43. https://doi.org/10.1002/1099-1573(200102)15:1\%3c39: AID-PTR684\%3e3.0.CO;2-R

Yilmaz Y, Toledo RT (2006) Oxygen radical absorbance capacities of grape/wine industry byproducts and effect of solvent type on extraction of grape seed polyphenols. J Food Compos Anal 19:41-48. https://doi.org/10.1016/j. jfca.2004.10.009

Yu O, Jez JM (2009) Nature's assembly line: biosynthesis of simple phenylpropanoids and polyketides. Plant J 54:750-762. https://doi.org/10.1111/j.1365-313X.2008. 03436.x

Zeneli G, Krokene P, Christiansen E, Krekling T, Gershenzon J (2006) Methyl jasmonate treatment of mature Norway 
spruce (Picea abies) trees increases the accumulation of terpenoid resin components and protects against infection by Ceratocystis polonica, a bark beetle-associated fungus. Tree Physiol 26:977-988. https://doi.org/10.1093/ treephys/26.8.977

Zinser C, Ernst D, Sandermann H Jr (1998) Induction of stilbene synthase and cinnamyl alcohol dehydrogenase mRNAs in
Scots pine (Pinus sylvestris L.) seedlings. Planta 204:169-176. https://doi.org/10.1007/s004250050243

Publisher's Note Springer Nature remains neutral with regard to jurisdictional claims in published maps and institutional affiliations. 